\title{
ATTORNEY-CLIENT RELATIONSHIPS IN CYBERSPACE: THE PERIL AND THE PROMISE
}

\author{
CATHERINE J. LANCTOT $\dagger$
}

\begin{abstract}
Despite the legal profession's historical resistance to technological advances, the burgeoning world of cyberspace is bringing change to the practice of law. As laypeople flock to the Internet to seek help with their legal problems, lawyers are going online to provide such assistance. Yet, these exchanges are occurring without close consideration of whether they create attorney-client relationships-the source of weighty ethical and legal obligations. In many cases, lawyers seek to avoid the consequences of such relationships merely by disclaiming their existence.
\end{abstract}

In this Article, Professor Lanctot examines the issue of lawyerlayperson communications in cyberspace from doctrinal and historical perspectives. The Article's analysis of the case law demonstrates that online exchanges resulting in the giving of specific legal advice likely will be viewed as creating attorney-client relationships. Moreover, disclaimers are unlikely to provide the protection that many lawyers seek. The Article then reviews the history of bar regulation of advice-giving in a variety of contexts, from the Good Will Court radio broadcasts of the 1930s to today's seminars and 900-number services. The Article shows that the bar consistently has both viewed the furnishing of particularized legal advice as creating an attorney-client relationship and frowned on such advice-giving in nontraditional contexts. The bar's cool response to forms of legal assistance spurred

$\dagger$ Professor of Law, Villanova University Law School. A.B. Brown University, 1978; J.D., Georgetown University Law Center, 1981. I would like to thank James Edward Maule, Henry H. Perritt, Jr., Stephen Gillers, my colleagues at Villanova Law School, and my research assistants Holly Sands, Jennifer Wojciekowski, Cara Leheny, and Jennifer Larkin. Special thanks to Michael Briechle for his tireless efforts in cataloging the many bar opinions cited in this Article. I welcome comments on the Article and can be reached via e-mail at lanctot@law.vill.edu. 
by new technology sounds a cautionary note for lawyers on the Internet.

Yet, if attorney-client relationships in cyberspace present some peril, through the specter of legal liability or of bar disciplinary action, they also present enormous promise for addressing the unmet legal needs of many Americans with lower incomes. Professor Lanctot concludes the Article by discussing the challenge of adapting the traditional, full-service model of attorney-client relationships to the question-and-answer format of cyberspace. One means of doing so, known as discrete task representation, may allow lawyers to avoid the legal and ethical pitfalls of online practice yet provide valuable legal assistance to those who cannot afford traditional representation.

\section{TABLE OF CONTENTS}

Introduction

I. Forming an Attorney-Client Relationship by Giving Legal

Advice

A. The Client Manifests an Intent to Receive Legal

Services

B. The Lawyer Manifests Consent to Provide Legal

Services

C. The Lawyer Fails to Manifest Lack of Consent, and the Lawyer Knows or Reasonably Should Know That the Person Reasonably Relies on the Lawyer to Provide the Services.

1. Using Disclaimers to Avoid Attorney-Client

Relationships.

2. Using Disclaimers to Limit the Scope of

Representation

D. Alternative Theories of Liability

1. Duties to Prospective Clients

2. Obligations to Nonclient Third Parties

II. "Swing-Time Justice": Regulating Radio Courts in the 1930s ..198

III. Regulating Legal Advice in Nontraditional Contexts

A. Modern Regulation of Legal Advice on Radio and

Television

B. Giving Legal Advice in Writing ...

1. Giving Legal Advice in Newspaper Columns

2. Giving Legal Advice in Books

C. Giving Legal Advice in Seminars 
D. Giving Legal Advice on the Telephone Through 900

Numbers

E. Giving Legal Advice in Cyberspace ................................244

F. The Past Is Prologue...................................................246

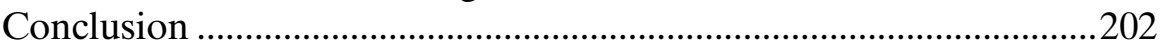

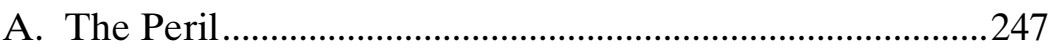

B. The Promise .............................................................................250

[T] he computer will obviously raise problems in particular areas of the law where it becomes a productive instrumentality replacing human beings .... The role for the law teacher as a leader in the development of the law is to anticipate those problems.... Out of such a fund of carefully considered writing, judges and legislators will find the means of dealing with computer bugaboos hypothecated by many writers.

William B. Eldridge, $1963^{1}$

Enough, if something from our hands have power

To live, and act, and serve the future hour.

William Wordsworth, $1820^{2}$

\section{INTRODUCTION}

Change comes slowly to the legal profession, even in the Digital Age. On the eve of a new millennium, American lawyers only now are beginning to perceive what much of the commercial world already understands - the potential that computer technology holds for transforming the way business will be done in the twenty-first century. Although most law firms today have some familiarity with the online world, ${ }^{3}$ far fewer have fully incorporated all the elements of

1. William B. Eldridge, Automation as a Challenge to Legal Education: A Defense of the Tried and True (1963), in COMMUNICATION SCIENCES AND LAW: REFLECTIONS FROM THE JuRIMETRICS CONFERENCE 15, 20-21 (Layman E. Allen \& Mary E. Caldwell eds., 1965).

2. William Wordsworth, The River Duddon: A Series of Sonnets (1820), in Poetical WorKs 296, 303 (Thomas Hutchinson \& Ernest De Selincourt eds., 1974).

3. In 1997, nearly two-thirds of American law firms had websites. See, e.g., Lawyers, Firms Vie for Visibility by Creative Use of Home Pages on Web, 66 U.S.L.W. 2652 (Apr. 28, 1998); Sharp Rise in Web Sites by Largest Firms, NAT'L L.J., Oct. 6, 1997, at B7 (indicating that $64 \%$ of firms in the top 250 had websites and that $33 \%$ had sites reportedly generating busi- 
digital technology into their daily practice of law. Indeed, there remains a sizeable segment of the profession that has never ventured into cyberspace and that seems to harbor latent nostalgia for the days of parchment and quill pens, or at least for mag cards and IBM Selectric typewriters. ${ }^{4}$ Yet, lawyers of the future will ignore cyberspace at their peril, because it is through that "unique and wholly new medium of worldwide human communication" that much of the legal business of tomorrow could be conducted.

ness). The most recent statistics indicate that $80 \%$ of small firms surveyed by the American Bar Association now use the Internet, up dramatically from 38\% in 1996. See Legal Tech. Resource Ctr., American Bar Ass'n, 1998 Small Law Firm Technology Survey (visited Sept. 10, 1999) $<$ http://www.abanet.org/tech/ltrc/98small.html> (on file with the Duke Law Journal). See generally Henry H. Perritt, Jr., How to Practice Law with Computers (3d ed. 1998) (explaining how computers, word processing, and electronic publishing can help attorneys practice law).

4. Anecdotal evidence of lawyer technophobia in the face of increasing computerization abounds. See, e.g., PARK B. Dilks, JR., Morgan, Lewis \& BockiUs, A LAW Firm AND ITS TIMES, 1873-1993, at 387 (1994) (stating that the firm refused to reimburse attorneys in 1980 for purchase of personal computers because it was possible that everyone would want one, which would be "ludicrous"); BENJAMIN WRIGHT, THE LAW OF ELECTRONIC COMMERCE 36 (1991) ("Attorneys are most comfortable when conservative. Either they want to do it the old way, or they want to see a herd doing it the new way."); Joan Countryman \& Gary Peterson, Improving Productivity with Computers, A Government Example, LEGAL ECON., Apr. 1988, at 51, 51 (quoting a government lawyer as saying: "Don't bother putting one of those terminals in my office. I won't use it.”); Vernon R. Proctor, Reality Bytes: A Luddite Lawyer Looks at Legal Technology, 14 DEL. LAW. 48 (1996) ("I am now the only lawyer in my office without a PC - a distinction that I wear as a badge of honor."); Wendy R. Liebowitz, Notes from the ABA Techshow: All Wired Up and Places to Go, NAT'L L.J., Apr. 28, 1997, at B9 (reporting that "[u]ntil recently there were two main obstacles to lawyers' using technology: lawyers and technology"); Stephan J. Mallenbaum, No, It's Not a Very Large Paperweight, N.Y.L.J., Jan. 22, 1993, at S1 ("[F]or many attorneys, the personal computer . . . serves as a fancy office ornament or as an expensive extra shelf for paper files."); Thom Weldlich, A Better Client Trap? Click Twice on Mouse for Legal Services, NAT'L L.J., Aug. 22, 1994, at A1 (claiming that lawyers are not known for "pioneering the use of new technologies"). Conservatism in the use of computers is not limited to lawyers, of course. The 1997 debate over whether laptop computers should be permitted on the floor of the U.S. Senate reflected similar tensions. See Eric Schmitt, Senator Tries a Trade Deal: His Briefcase for a Laptop, N.Y. TIMES, Aug. 10, 1997, at A22 ("[N]othing is simple when it comes to tinkering with the traditions of the United States Senate, whose chamber still has original 19th-century wooden desks, inkwells and spittoons.").

5. Reno v. American Civil Liberties Union, 521 U.S. 844, 850 (1997). As the Supreme Court explained:

Anyone with access to the Internet may take advantage of a wide variety of communication and information retrieval methods. . . Taken together, these tools constitute a unique medium-known to its users as "cyberspace," located in no particular geographical location but available to anyone, anywhere in the world, with access to the Internet.

Id. at 851 . 
Today, while the legal profession retains its historical ambivalence toward technological advances, laypeople are gravitating to the Internet to seek help with their daily legal problems, and they are beginning to find such help. A growing number of lawyers have begun to use the medium of cyberspace to give specific legal advice to laypeople who request it. This little-known phenomenon poses fundamental questions about the very nature of attorney-client relationships in the Digital Age.

Since few commentators have yet focused on the nature and scope of online legal advice, a brief surf of the Internet is in order before we begin. In cyberspace, the much-decried unmet legal needs of middle-income people are available for the world to see, with just a few clicks of a mouse. The Internet abounds with tales of legal woe, presented through a number of different vehicles. One way for laypeople to seek legal advice is through online newsgroups, which are discussion forums online, categorized by subject, in which people post and read messages at the newsgroup site. ${ }^{6}$ A representative newsgroup, alt.lawyers.sue.sue.sue, features countless pleas for legal assistance from laypeople who claim to have been injured in accidents, fired from their jobs, treated unjustly in a divorce proceeding, or otherwise confronted by a calamity requiring a legal response. ${ }^{7}$ In another type of discussion group, called a "listserv" or mailing list, messages are sent to a central e-mail address and then redistributed to

6. See id. ("Newsgroups . . . serve groups of regular participants, but these postings may be read by others as well. There are thousands of such groups, each serving to foster an exchange of information . . . on a particular topic . . . About 100,000 new messages are posted every day."). For a useful glossary of Internet terms, see PAUL S. JACOBSEN, NET LAw: How LAWYERS USE THE INTERNET 213-23 (1997).

7. See Current Topics in alt.lawyers.sue.sue.sue (visited Sept. 21, 1998) <alt.lawyers.sue.sue.sue> (on file with the Duke Law Journal). On September 21, 1998, for example, among the first few messages in the current topic list in alt.lawyers.sue.sue.sue were: "Do I have a case?-Neglect/Failure to Warn? (Texas)"; "Hearing Loss at employmentworth suing?"; and "dog bite." See id. A typical posting begins as follows:

I had sinus surgery and the doctor messed up my eye and I now have double vision. I have tried to sue for malpractice but have not been able to find another doctor to testify against the doctor. Apparently - double vision is on [sic] of the possible side effects. ... Can I sue him for failing to warn me?

Tully Ward, Do I Have a Case?-Neglect Failure to Warn (Texas) (posted Sept. 21, 1998) $<$ alt.lawyers.sue.sue.sue> (on file with the Duke Law Journal). Similar claims abound at other newsgroups like misc.legal and alt.self-help-law. The sheer volume of information on the Internet makes it impossible to identify every law-related newsgroup online with any assurance that the list is complete. A good source for finding newsgroups is Dejanews. See Deja.com (visited Sept. 20, 1999) <http://www.deja.com> (on file with the Duke Law Journal). 
the list's subscribers; some such lists may also feature requests for legal advice. ${ }^{8}$ A different version of these groups is the "chat room," in which two or more individuals may communicate in "real time," receiving responses on the screen as soon as they are typed in. 'Lawyers occasionally answer these questions, often while simultaneously disclaiming any intent to form an attorney-client relationship. ${ }^{10}$

Specific websites have also been established to facilitate requests for legal advice. One early site was Dear Esquire, described by one commentator as "a sort of legal on-line 'Dear Abby' where the question-and-answer process is formalized and limited by restrictions and warnings in an evident effort to minimize liability." has proved to be a prototype for many other sites, such as FreeAdvice and LawGuru. ${ }^{12}$ These sites encourage laypeople to post legal ques-

8. Pages at the University of Chicago and Findlaw.com websites contain good compilations of such legal listservs. See Findlaw LegalMinds (visited Sept. 20, 1999) $<$ http://www.findlaw.com/lists> (on file with the Duke Law Journal); Index of / llou/lawlists (visited Sept. 20, 1999) <http://www.lib.uchicago.edu/ llou/lawlists $>$ (on file with the Duke Law Journal).

9. See Reno, 844 U.S. at 851-52. ("In addition to posting a message that can be read later, two or more individuals wishing to communicate more immediately can enter a chat room to engage in real-time dialogue-in other words, by typing messages to one another that appear almost immediately on the others' computer screens."). One such site is DivorceNet Chat, which features conversations about divorce issues. See DivorceNet Chat (visited Sept. 20, 1999) $<$ http://www.divorcenet.com:3335> (on file with the Duke Law Journal). DivorceNet Chat is linked to the Family Law Advisor Home Page. See www.DivorceNet.com (last modified Aug. $26,1999)<\mathrm{http}: / /$ www.divorcenet.com> (on file with the Duke Law Journal). Its disclaimer asserts: "Nothing contained on the messages board should be construed as 'legal advice' nor is an attorney-client relationship created by virtue of any communication." Password Administration - Create a New Account (visited Sept. 20,1999) <http://www.divorcenet.com/forum2/new.html> (on file with the Duke Law Journal). There are other chat rooms at sites such as prairielaw.com and Legal dot Net. See prairielaw.com (visited Sept. 20, 1999) <http://forums.prairielaw.com> (on file with the Duke Law Journal); The Forum (visited Sept. 20, 1999) $<$ http://chat.legal.net:8080> (on file with the Duke Law Journal).

10. It bears mentioning that, although the responses purport to come from lawyers, identity in cyberspace may still be easily concealed or falsified. For our purposes, we shall assume that the online legal advice postings we are discussing were posted by attorneys.

11. Joan C. Rogers, Ethics, Malpractice Concerns Cloud E-Mail, On-Line Advice, 12 Laws. Man. on Prof. Conduct (ABA/BNA), Mar. 6, 1996, at 59, 70.

12. FreeAdvice.com, describing itself as having been rated the most useful consumer legal site in a USA Today poll, claims to provide "general legal information," but says it is not a "substitute for personal legal advice." FreeAdvice.com (visited Sept. 20, 1999) $<$ http://www.freeadvice.com> (on file with the Duke Law Journal). Like most similar attorney websites, LawGuru.com, sponsored by the law firm of Eslamboly \& Barlavi of Los Angeles, features a detailed disclaimer that the questioner is expected to check off and to agree to before submitting a query. The disclaimer warns that the information given cannot "replace a face-to-face meeting or telephone consultation with a 'real live' attorney" and states that no 
tions, identifying their state of residence, and suggest that lawyers who are licensed to practice in those states post responses. ${ }^{13}$ The questions and the answers are publicly available to anyone who accesses the websites. ${ }^{14}$ Consider one typical exchange on the Dear Esquire site:

Dear Sirs As a medical student in July of 1993 I injured my right leg on school property at the University of Pittsburgh childrens hospital I was not aware that I would become chronic causing me pain an suffering when I stand or walk for any length of time. Until March or February of 1994 a MRI shows damage to the joint membrane causing swelling and pain to the joint I have had multiple injections of the leg and it helps buy when I have to stand or walk for any period of time I suffer great Pain, I am now living in California. With my parents no job med school loans and great pain Can I file any suit for damages?

A reply, signed by a lawyer, read as follows:

attorney-client relationship will be created in the absence of a written representation/retainer agreement, even if a response was given to a question. LawGuru.com (visited Sept. 20, 1999) $<$ http://www.lawguru.com/cgi/bbs2/user/submit.cgi> (on file with the Duke Law Journal). For examples of other consumer legal sites, see prairielaw.com (visited Sept. 20, 1999) $<$ http://prairielaw.com> (on file with the Duke Law Journal) (offering e-mail discussion groups, message boards, and articles on legal topics); Martindale-Hubbell's Lawyers.com (visited Sept. 20,1999 ) <http://www.lawyers.com> (on file with the Duke Law Journal) (featuring a questionand-answer service). One cautionary note for anyone studying this area is that websites come and go without warning. The website of CourtTV, the cable television station, once featured a similar question-and-answer format called Ask-A-Lawyer, which has since apparently been discontinued.

13. See, e.g., LawGuru.com (visited Sept. 20, 1999) $<$ http://www.lawguru.com/cgi/bbs2/user/submit.cgi> (on file with the Duke Law Journal).

14. See, e.g., Dear Esquire: Submit a Question (visited Sept. 17, 1999) $<$ http://www.legal.net/ldn2/index-c1.htm> (on file with the Duke Law Journal). Among the issues and questions posted at the site are: "Am I Married?"; "Can they fire me after 29 years of employment?"; "Cleaner destroys sweater"; "Creditors are telling me they are going to garnish my wages"; and "My landlord is evicting me because I have a dog." Id. The questioner is asked to check a box online to signify agreement with a disclaimer, which reads:

I agree to not rely on any information that might be provided in response to questions submitted to Dear Esquire. I understand that the information provided in this column is not intended to be a substitute for the services of a competent legal professional and that I should seek the advice of a legal professional in all matters which may require legal advice or action.

Id. A similar website, The Law Office, also provides answers to legal questions. See The Law Office (visited July 23, 1997) <http://www.thelawoffice.com> (on file with the Duke Law Jour$n a l)$. That site's disclaimer reads: "The Law Office Inc. is not engaged in the practice of law. It is understood that non-professionals using information from The Law Office for self-help are acting as their own attorney. If the services of a lawyer are desired, you should enter into an attorney-client relationship." Id. 
You now face many obstacles which would prevent recovery for the injuries you sustained in July of 1993. The statute of limitations in Pennsylvania for such injury is two years. You would have been required to commence a legal action for such recover no later that July of 1995. Additionally, the Pennsylvania Tort Claims Act requires that you notify any governmental agency within one year of the injury. It appears that you have taken neither act required and my opinion is that you are now barred for recovery from this accident. ${ }^{15}$

This legal advice, which is fairly typical of that found on these websites, is specific, tailored to the facts furnished by the questioner, and given as if it were definitive.

Another way for laypeople to seek legal advice online is to go to the websites of individual attorneys or law firms and to send questions directly to the attorneys by e-mail. These sites differ from the preceding two types of sites in that neither the questions nor the answers are visible to the public. The sheer volume of material on the Internet makes it impossible to catalog all the relevant sites, but we can consider a few representative examples. One free site is the website of the Goodman Law Firm in Arizona, which offers a "Debt Collection Claim Evaluation." The firm promises a "free evaluation of your debt collection claim" upon submittal of an online form. ${ }^{17}$ Other law firms' sites also feature online client intake forms, without expressly offering to provide legal advice through the Internet. ${ }^{18}$

More recently, some lawyers have begun using the Internet to offer answers to legal questions for a fee. Richard R. Baker's site, ti-

15. I Injured My Leg on School Property, Can I File Any Suit for Damages?(visited Sept. $21,1999)<\mathrm{http}: /$ www.legal.net/ldn2/index-c1.htm > (all mistakes are reproduced as in original) (on file with the Duke Law Journal).

16. Goodman Law Firm, P.C. (visited Sept. 20, 1999) <http://www.goodmanlaw.com> (on file with the Duke Law Journal).

17. Goodman Law Firm, Debt Collection Claim Evaluation (visited Sept. 20, 1999) $<$ http://www.goodmanlaw.com/debt.htm> (on file with the Duke Law Journal). The form further provides: "If you have not received a response within 72 hours, please call our office." Id. Another lawyer's website offers to answer or to refer legal questions for no charge, with the questioner agreeing that he is "forming only a semi-confidential relationship," and further agreeing not only that the request does not create an attorney-client relationship, but also that the questioner "may only retain an attorney by entering into a fee agreement, and that [he is] not hereby entering into a fee agreement." Law Offices of Herbert Monheit, Post Free Legal Question (visited Sept. 20, 1999) <http://www.civilrights.com/caseform.html > (on file with the Duke Law Journal).

18. See, e.g., Siskind, Susser, Haas \& Devine, US Offices Consultation Questionnaire Form (visited Sept. 20, 1999) <http://www.visalaw.com/intake.html> (on file with the Duke Law Journal) (featuring a client intake form for an immigration law firm). 
tled LegalQuestion.com, is typical of these sites. It provides the following terms:

You, the Questioner/Client will ask a short legal question of 200 words or less and our firm will provide a written e-mail response for a fee of $\$ 25$ which will be billed to your credit card via our secure server. Each question will be responded to within a reasonable time and although both parties understand that an Attorney/Client relationship may be created hereby, it is understood and agreed to that such relationship will terminate upon the sending of our e-mail response to your e-mail address and no further legal services or advice will be required. It is further agreed to by you that the submission of your question shall not place upon Attorneys the duty to protect any statute of limitations or any other rights on your behalf or cause Attorneys to have a duty to take any action in any court of law, unless we agree in writing. ${ }^{19}$

Other sites purport to provide similar services. ${ }^{20}$ Unlike the other types of sites discussed earlier, fee-based legal advice sites tend to acknowledge the possibility of an attorney-client relationship, but use disclaimers in attempts to limit the duties attorneys might owe to their cyberclients.

This brief survey has provided an overview of how laypeople currently use the medium of cyberspace to seek legal advice. Not only are there endless variations on these types of communication, but the rapid technological changes that have characterized the

19. Law Offices of Richard P. Baker, P.A., Legal Services Agreement-Terms and Conditions (visited Sept. 20, 1999) <http://www.legalquestion.com/ask-a-question-terms.html > (on file with the Duke Law Journal). The disclaimer further purports to limit the attorneys' liability for the answers and to waive confidentiality and conflicts of interest, and rather brazenly asserts: "You further understand and are advised that there is no malpractice insurance for internet advice." Id.

20. See, e.g., Ask-A-Lawyer (visited Sept. 20, 1999) <http://www.ask-a-lawyer.com> (on file with the Duke Law Journal). The site of Peter R. Stone offers to answer a short legal question for $\$ 20$. See id. The disclaimer resembles the one above, acknowledging the possibility that the exchange creates an attorney-client relationship but purporting to limit any duties to the client. See Limitation of Liability (visited Sept. 20, 1999) <http://www.ask-alawyer/disclaimer.html> (on file with the Duke Law Journal). Another example is the website of Levine \& Yates of Arlington, Virginia. See Law Offices, Levine and Yates (visited Sept. 20, 1999 ) <http://www.visa-usa.com> (on file with the Duke Law Journal) (offering immigration and citizenship law advice). In a published interview, one of the attorneys from that firm "acknowledged that once payment is accepted, the e-mail correspondent becomes 'our client,' and the firm treats the Internet contact as seriously [as] if it were an office consultation." William C. Smith, Offering Legal Advice over Internet May Lead to Cyber-Malpractice, LEGAL INTELLIGENCER, May 19, 1997, at 6. 
Internet in recent years no doubt will yield further innovations not anticipated here. Although the proliferation of this activity has received little publicity, what may be most surprising to the casual observer is not that so many laypeople want legal advice to help them solve their problems. Rather, it is that so many lawyers are apparently willing to provide it. ${ }^{21}$

The emergence of these new and largely unexamined methods of delivering legal services has profound implications for the practice of law in the twenty-first century. ${ }^{22}$ On one hand, the millions of Americans whose legal needs have largely gone unmet in recent years may finally have recourse: an army of cyberlawyers, ready and willing to answer legal questions online, either for free or for a small fee. On the other hand, the specter of lawyers casually typing out off-the-cuff responses to questions posed by strangers and posting them online for all the world to see must be the stuff of a bar regulator's nightmares. Online advice-giving raises a host of ethical issues. Public exchanges of often-sensitive personal information and specific legal advice present questions of confidentiality. Lawyers answering legal questions about which they have little or no expertise may violate the duty of competency. The possibility that a lawyer might inadvertently create a conflict of interest by answering legal questions from someone with an interest adverse to a current or former client is particularly troubling in the sometimes-anonymous world of cyberspace. Lawyers answering questions about the law in jurisdictions in which they are not licensed to practice may violate restrictions against the unauthorized practice of law. Most notably, the likelihood that some disgruntled recipient of negligent online legal advice will sue for malpractice lurks over all.

21. The potential use of discussion groups for marketing legal services is discussed in some detail in JACOBSEN, supra note 6, at 130 (quoting a lawyer as saying: "I know one American lawyer who has generated over $\$ 500,000$ in business in 18 months on the newsgroups."). Jacobsen notes that some newsgroups seem to be "full of people seeking free legal advice." Id. at 132.

22. See Richard S. Granat, From Legal Services to Information Services (last modified May 5, 1999) <http://www.digital-lawyer.com/legalservice.html> (on file with the Duke Law Journal) ("The day when people can ask their computers an intelligent question and get a relevant answer at low cost from the convenience of their homes is the day that many lawyers will be looking for work.").

23. For a general overview, see CATHERINE J. LANCTOT, Legal Ethics and the Internet, in THE InTERnet Guide For PENNSylvania LaWyers 117 (Pennsylvania Bar Institute ed., 1997); William C. Smith, Ethical Entanglements on World Wide Web, LEGAL INTELLIGENCER, May 8, 1997, at 1. 
Before any of this parade of horribles can be addressed, however, one threshold question must be resolved: does giving legal advice to a layperson create an attorney-client relationship? If it does not, then the online exchanges I have described may evoke regulatory concerns about advertising and solicitation, but they do not trigger the weighty obligations inherent in attorney-client relationships. ${ }^{24}$ On the other hand, if giving legal advice under certain circumstances can make the recipient a client, the traditional duties of confidentiality, competence, and loyalty, as well as other obligations, are fully implicated.

The ethical questions arising from lawyers' expanding use of the Internet have not yet generated the scholarly focus that they clearly deserve, ${ }^{25}$ although some practitioners have contended that there are no legal barriers to online advice. ${ }^{26}$ Those few commentators to have

24. Additionally, even where an attorney-client relationship is not formed, a lawyer may owe comparable fiduciary duties to prospective clients and third parties. See infra Part I.D.

25. To the extent that there has been some consideration of ethical issues for lawyers in cyberspace, it has centered largely on questions of advertising and solicitation raised by attorney websites, as well as on confidentiality issues presented by e-mail communications. For discussions of advertising and solicitation issues, see generally Ethics, Malpractice Concerns Cloud E-Mail, On-Line Advice, supra note 11; Brian G. Gilpin, Attorney Advertising and Solicitation on the Internet: Complying with Ethics Regulations and Netiquette, 13 J. MARSHALL J. COMPUTER \& INFO. L. 697 (1995); T.K. Read, Pushing the Advertising Envelope: Building Billboards in the Sky Along the Information Superhighway, 23 W. ST. U. L. REV. 73 (1995); Ann Davis, Firms Join the Web Marketing Craze, NAT'L L.J., Feb. 12, 1996, at A1; William E. Hornsby, Jr., Ethics Rules for Ads May Cover Web Sites, NAT'L L.J., Jan. 29, 1996, at C1; David P. Vandagriff, Marketing in Cyberspace, A.B.A. J., July 1995, at 84. Discussions of e-mail issues include Lucy Schlauch Leonard, Comment, The High-Tech Legal Practice: Attorney-Client Communications and the Internet, 69 U. CoLO. L. REV. 851 (1998); Jonathan Rose, Note, EMail Security Risks: Taking Hacks at the Attorney-Client Privilege, 23 RUTGERS COMPUTER \& TECH. L.J. 179 (1997); Amy M. Fulmer Stevenson, Comment, Making a Wrong Turn on the Information Superhighway: Electronic Mail, the Attorney-Client Privilege and Inadvertent Disclosure, 26 CAP. U. L. REV. 347 (1997). The best source for current bar opinions, as well as commentary on various ethical issues, is the website Legalethics.com, maintained by attorney Peter Krakaur. As of September 21, 1999, he listed 50 ethics opinions that relate either to the Internet or to other forms of electronic communication. See Legalethics.com: Ethics Opinions (last modified Feb. 1, 1999) <http://www.Legalethics.com/opins.htm> (on file with the Duke Law Journal). Many of the opinions address the issue of confidentiality in e-mail communications with clients. It should also be noted that the ABA has recently recognized the challenges posed by cyberspace, circulating a draft report that focuses in particular on the application of the Model Rules of Professional Conduct to legal marketing on the Internet. An index to the report is available at the website Legalethics.com. See Index of /articles/aba (visited Sept. 20, 1999 ) <http://www.legalethics.com/articles/aba> (on file with the Duke Law Journal).

26. See JACOBSEN, supra note 6, at 134-35:

If you are an attorney on the net and haven't given free advice at cocktail parties or over the Net, you are a strange bird indeed. . . . [You] advise them, generally, how 
noted the existence of these lawyer-layperson exchanges in cyberspace generally have warned of the potential pitfalls associated with giving legal advice online to strangers. ${ }^{27}$ In the past few years, a hand-

various laws may be applied to the facts. The advice really is always that a more thorough investigation of certain legal issues and facts is required, that the person should employ counsel ASAP for specific, stated reasons, and that upon more thorough investigation other laws and issues may be important. Now, this is legal advice-but I fail to see how it constitutes the unauthorized practice of law in any jurisdiction or is likely to constitute "wrong" advice or unauthorized practice that will get anyone into trouble when offered by an attorney who is licensed to practice in the state where he/she is physically located.

(quoting attorney Michael Daymude).

27. See Kathryn M. Fenton, Legal Ethics and the Internet, ANTITRUST, Summer 1997, at 43, 45:

Correctly identifying such inquiries as opportunities for demonstrating substantial expertise that might land a new client representation, attorneys and law firms have been known to prepare elaborate and highly detailed responses to Internet inquiries. Depending on the level and nature of the information received and the advice provided, however, attorneys may be dismayed to discover that through such communications they have inadvertently created an attorney-client relationship with the requesting party.

See also Peter Krakaur, The Internet: An Ethics Wake-Up Call (visited Sept. 20, 1999) $<$ http://www.collegehill.com/ilp-news/ilpn2.txt> (on file with the Duke Law Journal):

Given the relative novelty associated with this method of communication, however, many attorneys seem to ignore some of the traditional screening mechanisms they employ over the telephone or in person when asked a legal question. For example, if an individual enters an attorney's office, stops an attorney on the street, or calls an attorney on the telephone with a specific legal question, most attorneys conduct some form of conflicts analysis and discuss attorney-client communication issues with the individual. On the Internet, it often seems that such caution is ignored.

See generally LaWrence J. Fox, Legal Tender: A Lawyer's Guide to Handling PROFESSIONAL DILEMMAS (1995) (providing fictional stories to illustrate potential ethical dilemmas); JACOBSEN, supra note 6, at 80 ("Be aware of the risk that an email correspondent may assume you are acting as his or her lawyer and will rely on anything you say."); Brad Hunt, Comment, Lawyers in Cyberspace: Legal Malpractice on Computer Bulletin Boards, 1996 U. CHI. LEGAL F. 553 (1996) (arguing that a disclaimer will shield attorneys from liability for their posts to legal bulletin boards); Natacha D. Steimer, Note, CyberLaw: Legal Malpractice in the Age of Online Lawyers, 63 GEO. WASH. L. REV. 332 (1995) (asserting that a lawyer should be accountable for the consequences of a negligent post to a legal bulletin board); Richard S. Zembek, Comment, Jurisdiction and the Internet: Fundamental Fairness in the Networked World of Cyberspace, 6 ALB. L.J. SCI. \& TECH. 339 (1996) (examining jurisdictional issues in cyberspace); Josh Blackman, Crossing the Ethical Line Online, LAW OFFICE COMPUTING, Feb.Mar. 1996, at 64 (urging the ABA and state bar associations to issue advisory opinions on online legal advice); Maureen Castellano, Policing Cyberspace, N.J.L.J., Apr. 8, 1996, at 1 (citing conflicting views on the subject of online legal advice in New Jersey); Daniel B. Kennedy, PC Practitioners Proliferate, A.B.A. J., June 1993, at 36 (advising caveat emptor with regard to online legal advice); Wendy R. Leibowitz, Policies Set the Tone-and Just May Save a Firm from Litigation, NAT'L L.J., Oct. 14, 1996, at B20 (recommending that firms set clear policies on 
ful of bar opinions from several jurisdictions have reached varying conclusions about whether the giving of legal advice online creates an attorney-client relationship, ${ }^{28}$ but as yet there has not been a detailed legal analysis of the issue. Most commonly, lawyers attempt to avoid the myriad problems raised by this conduct by including a disclaimer in the advice given, thus theoretically defeating a later claim by the recipient of the information. ${ }^{29}$ To date, however, there has been very

technology use); Smith, supra note 20, at 6 (urging application of common sense to the issue of online legal advice).

28. See, e.g., State Bar of Ariz. Comm. on Rules of Prof'l Conduct, Op. $97-04$ (1997) (recommending that lawyers should "probably not" answer questions raised in chat rooms online); Ill. St. Bar Ass'n, Op. 96-10 (1997) (stating that "lawyers participating in chat-groups or other on-line services that could involve offering personalized legal advice to anyone who happens to be connected to the service should be mindful that the recipients of such advice are the lawyer's clients, with the benefits and burdens of that relationship"); Phila. Bar Ass'n Prof'l Guidance Comm., Op. 98-6 (1998) (cautioning that lawyers should be careful about creating attorneyclient relationships when answering legal queries online); S.C. Bar Ethics Advisory Comm., Op. 94-27 (1995) (permitting online legal discussions "solely for the purpose of discussing legal topics generally, without the giving of advice or the representation of any particular client"); Tenn. Sup. Ct. Bd. of Prof'l Responsibility, Op. 95-A-576 (1995) (unpublished opinion) (on file with the Duke Law Journal) (stating that lawyers may respond to lay requests through private e-mail, but should be aware that giving specific legal information may create an attorney-client relationship); cf. Or. St. Bar Ass'n Legal Ethics Comm., Op. 1994-137 (1994) (permitting the development of an online legal data base that would furnish information in response to inquiries, but would not be staffed by a live person).

29. Most commercial sites or attorney sites that purport to dispense advice include some type of disclaimer. See, e.g., Dear Esquire (visited Sept. 17, 1999) $<$ http://www.legal.net/ldn2/index-c1.htm> (on file with the Duke Law Journal):

The purpose of Dear Esquire is to educate the public about legal options that may exist. Dear Esquire is not intended to provide specific legal or other professional advice upon which guests may rely. Posting of answers in no way constitutes an endorsement ... of the information given by individual attorneys, paralegals or law students. Guests are advised and encouraged to seek the help of a competent legal professional in all matters where specific legal advice and/or action may be required.

One commentator has recommended using the following disclaimer:

This Web page is a public resource of general information which is intended, but not promised or guaranteed, to be correct, complete and up-to-date. However, this Web page is not intended to be a source of advertising, solicitation, or legal advice; thus the reader should not consider this information to be an invitation for an attorneyclient relationship, should not rely on information provided herein and should always seek the advice of competent counsel in the reader's state.

Jeffrey R. Kuester, Attorney Sites Can Avoid Violations of Ethics Rules, NAT'L L.J., Aug. 12, 1996, at B11. Large law firms tend to include extensive disclaimers on their websites. See Wendy R. Liebowitz, The Sins of Law Firm Web Sites: Are Ethical, Dignified Sites Dull?, NAT'L L.J, Aug. 18, 1997, at B6 (describing King \& Spaulding's "mother of all legal disclaimers" on its website, www.kslaw.com). 
little analysis of whether such disclaimers would actually be effective in a malpractice claim by a disappointed cyberclient. ${ }^{30}$

Because giving legal advice on the Internet raises ethical questions that are likely to be confronted by every state bar disciplinary authority in the next several years, the issue of legal advice-giving on the Internet warrants close examination now, while the technology remains in its relative infancy. In this Article, I shall examine the question of whether giving legal advice online creates an attorneyclient relationship from two different perspectives. ${ }^{31}$ In Part I, I consider this question from a doctrinal point of view, examining both the recently adopted Restatement (Third) of the Law Governing Lawyers and the case law that addresses formation of attorney-client relationships. $^{32}$ This review demonstrates that courts traditionally have been

30. See Castellano, supra note 27, at 1 (describing conflicting views about the effectiveness of disclaimers); Peter Krakaur, The Ethics of Giving Casual Legal Advice Online (visited Sept. 20, 1999) <http://www.ljx.com/newsletters/internet/1998/1998_05_00.html> (on file with the Duke Law Journal) ("Sharp, relevant disclaimers can help frame the nature of the exchange, but attorneys ought not rely on them exclusively."); J.T. Westermeier \& Leonard T. Nuara, Ethical Issues for Lawyers on the Internet and World Wide Web, COMPUTER LAW., Mar. 1997, at 8, 13 (noting inconsistent advice on effectiveness of disclaimers); Todd Woody, An Internet Free-for-All, CONN. L. TRIB., June 10, 1996, at 26 (regarding a disclaimer as an "electronic talisman to ward off malpractice suits, disciplinary charges and other potential pitfalls that come with being on the cutting edge of law and technology").

31. Before considering the implications of online advice-giving by lawyers, it is important to distinguish this conduct from other kinds of Internet activity. First, although many lawyer websites contain information about the law, and sometimes statutes or cases themselves, this type of information is not "legal advice" for purposes of our discussion, because the information is not provided in response to a query from a layperson. See, e.g., Arent Fox Publications (visited Sept. 20, 1999) <http://www.arentfox.com/publicat.html> (on file with the Duke Law Journal) (containing newsletters on legal topics written by attorneys of the Arent Fox law firm). Merely posting legal information on websites may raise other ethical issues, but it does not constitute legal advice. Also outside the scope of this discussion is legal advice given online by a lawyer to an existing client, or given with the express understanding that a traditional attorney-client relationship is being created. Again, such activity generates ethical concerns about confidentiality and the unauthorized practice of law, but the question of whether an attorney-client relationship has been created is not at issue. Finally, preparation of legal forms by non-lawyers through exchange of information via the Internet poses questions about the unauthorized practice of law, but this kind of interaction ordinarily does not purport to create attorney-client relationships. These activities do raise a myriad of ethical issues that merit scholarly attention in the future.

32. I believe that lawyer activity on the Internet can be analyzed under traditional legal principles, just as any of the other activities in which lawyers regularly engage, and I reject the notion that an entirely new body of "cyberlaw" must be created to cope with the innovations sparked by the "Computer Revolution." At the same time, I acknowledge that the medium of digital communications may pose unique problems to which the law must adapt, just as the law 
willing to infer attorney-client relationships when lawyers give specific legal advice to laypeople under circumstances in which it would be reasonable for them to rely on the advice. Courts have treated the giving of legal advice as the essence of the practice of law, and under certain circumstances, advice that is specific to the unique set of facts advanced by the questioner is likely to provide a basis for imposing all the duties inherent in a more traditional attorney-client relationship. Indeed, even without the creation of a formal attorney-client relationship, lawyers may incur obligations from their receipt of confidential information, such as in preliminary consultations to determine whether to take a case. I also address the question of disclaimers, showing that there is substantial doubt about whether even a carefully worded disclaimer could defeat a subsequent claim against a lawyer who gave specific legal advice online.

Common law provides a substantial basis for imposing the obligations of an attorney-client relationship on lawyers who give specific legal advice to laypeople online, but the precedent is hardly conclusive. For that reason, in Parts II and III, I turn to the history of bar regulation of such conduct to see how the norms of the profession have treated the act of giving legal advice outside formally created professional relationships. This empirical study shows that, at least since the 1930s, bar opinions in a variety of different contexts have asserted that furnishing more than generalized legal information can create an attorney-client relationship between the lawyer and the questioner. The historical record also reflects that the regulatory responses to such conduct have often been prompted by technological advances. It is for this reason that I begin my historical survey in Part II with the long-forgotten story of the Good Will Court, an innovative method of giving legal advice over the radio that emerged in the

has adapted throughout history to technological developments. See Mitchel L. Winick et al., Attorney Advertising on the Internet, 27 TEX. TECH L. REV. 1487, 1528 (1996):

Cyberspace is a world created for multi-dimensional communication in diverse forms. In one form, it is comparable to traditional . . communication such as print and broadcast media. In another form, it is comparable to interactive communication such as telephones. In any form it is flexible, allowing the exchange of ideas personto-person, group-to-group, privately or publicly. Cyberspace communication is like everything we have known about communication-and like nothing we have ever known.

There remains some debate as to whether new ethical rules are required to address issues arising from lawyer activity in cyberspace. See Wendy Leibowitz, Legal Ethics in an Electronic Age: Where No One Has Gone Before?, NAT'L L.J., Mar. 24, 1997, at B8 (noting the controversy over whether existing ethical rules suffice). 
1930s, only to be rapidly suppressed by the organized bar. The bar's response to the then-revolutionary technology of radio, used as a forum for laypeople to describe their legal problems and to receive free legal advice from lawyers and judges, stands as a cautionary tale for lawyer activity on the Internet.

As I shall show in Part III, the organized bar has attempted since the 1930s to regulate the giving of specific legal advice in a variety of other contexts, such as radio and television call-in shows, newspaper advice columns, books, seminars, and 900-number telephone lines. In each instance, the bar has attempted to distinguish between the transmission of general legal knowledge, which it has viewed as permissible, and the presentation of specific legal advice tailored to an individual's particular problem, which it has treated as impermissible. Particularly noteworthy in this record is the skepticism of bar regulators-who have purported to regulate such advice-giving in the name of consumer protection-regarding the use of disclaimers to avoid the evils that might flow from these exchanges of advice. Often, however, the bar's reaction to such innovations has reflected unspoken concerns about the image of lawyers generally, and about the economic consequences that could flow from less-structured professional relationships.

I conclude that giving specific legal advice to online questioners ordinarily will create an attorney-client relationship. But what are the ramifications of this conclusion for future regulation of this conduct? Based on legal precedent and on historical experience, one might confidently predict that the organized bar will react with reflexive hostility to the emergence of online legal advice-giving. ${ }^{33}$ Consider for a moment the legal profession's record with respect to another revolutionary form of communication-the telephone. The invention of the telephone transformed communications and made the emergence of large business entities possible. ${ }^{34}$ Although extravagant claims

33. See Kuester, supra note 29, at B11 ("The disdain with which many attorneys view lawyer advertising and unauthorized practice of law is likely to exacerbate traditional technophobia and the temptation to apply to the dynamic realm of multimedia rules specifically written for the static media of the past.").

34. Alexander Graham Bell received his patent on the telephone on March 7, 1876. See THE REAdER's COMPANION TO AMERICAN History 90-91 (Eric Foner \& John A. Garraty eds., 1991). President Rutherford B. Hayes installed the first telephone in the White House in 1878, the same year that New Haven, Connecticut, opened the first telephone exchange in America. In less than 25 years, there were 1.5 million telephones in the United States. JAMES West DaVidson et AL., NATION OF NATIONS: A NARRATIVE History OF THE AMERICAN 
were made concerning the telephone's potential to revolutionize society, ${ }^{35}$ many people remained unconvinced, at least initially, about the telephone's value in business transactions. ${ }^{36}$ In fact, Alexander Graham Bell's prospective father-in-law, a Boston lawyer, dismissed the invention as "only a toy" and attempted to discourage him from pursuing its development. ${ }^{37}$

As telephones came into the law offices of the late nineteenth century, attorneys often greeted their arrival skeptically. ${ }^{38}$ One author has envisaged the scene:

It is easy to imagine the telephone salesman endeavoring to convince lawyers of the benefits of the telephone, and just as easy to imagine that before we lawyers would admit this new invention into our law offices, we would insist on carefully considering all the consequences, especially those relating to our rules of professional responsibility. Thus, no doubt our first reaction to the possibility of installing a telephone was a resounding no.

REPUBLIC 653 (1990). Nevertheless, on the eve of the Japanese bombing of Pearl Harbor, only about $40 \%$ of all American households had telephones. See Claude S. Fischer, AmERICA CALling: A SOCIAL History OF THE TELEPHONE TO 1940, at 255 (1992).

35. Much of the early rhetoric about the telephone mirrors contemporary claims about computers. In The History of the Telephone, a Bell Telephone-sponsored paean to the invention, the author confidently proclaimed:

With the use of the telephone has come a new habit of mind. The slow and sluggish mood has been sloughed off. The old to-morrow habit has been superseded by "Do It To-day"; and life has become more tense, alert, vivid. The brain has been relieved of the suspense of waiting for an answer, which is a psychological gain of great importance.

Herbert N. CASSON, THE History OF THE TELEPHONE 231-32 (1910).

36. See John Brooks, The First and Only Century of Telephone Literature, in THE SocIAL IMPACT OF THE Telephone 208, 211-12 (Ithiel de Sola Pool ed., 1977) (describing the bias against the telephone held by many literary men who thought that it threatened their privacy). "Public officials, even in the United States, have been slow to change from the old-fashioned and more dignified use of written documents and uniformed messengers; but in the last ten years there has been a sweeping revolution in this respect." Id. at 201. Bell Telephone's history of the telephone, published in 1910, recalled: "So entirely has the telephone outgrown the ridicule with which, as many people can well remember, it was first received, that it is now in most places taken for granted, as though it were a part of the natural phenomena of this planet." CASSON, supra note 35 , at $\mathrm{v}$.

37. Christopher Cerf \& Victor Navasky, The Experts Speak: The Definitive COMPENDiUM OF AUTHORITATIVE Misinformation 205 (1984) (quoting Gardiner Greene Hubbard's advice to his prospective son-in-law, Alexander Graham Bell).

38. For a description of law practice at the turn of the century, see Harry J. Lambeth, Practicing Law in 1878, 64 A.B.A. J. 1014, 1015-23 (1978).

39. Louis M. Brown, Emerging Changes in the Practice of Law, 1978 UTAH L. REV. 599, 599; see also Colleen L. Rest, Note, Electronic Mail and Confidential Client-Attorney Communications: Risk Management, 48 CASE W. RES. L. REV. 309, 309 (1998) (describing lawyers torn 
Lawyers also greeted the advent of other business machines like typewriters with deep suspicion. ${ }^{40}$ Future Secretary of State John Foster Dulles recalled that when he joined the large New York law firm of Sullivan \& Cromwell in 1911, neither telephones nor stenographers were widely accepted as part of traditional law practice. ${ }^{41} \mathrm{He}$ remembered that "[s]ome of the older partners felt that the only dignified way of communication between members of the legal profession was for them to write each other in Spencerian script, and to have the message thus expressed [sic] delivered by hand." ${ }^{42}$ In fact, Sullivan \& Cromwell did not obtain a telephone until 1887, nearly a decade after the invention became available, and that telephone was a wall phone located in the outer office, which the clerks were forbidden to touch except when it rang. ${ }^{43}$

by a concern that use of the telephone would violate confidentiality but that failure to use the telephone would be inefficient). In response to these concerns, one author invented a substantial legal telegraphic code to preserve confidentiality. See Frank W. Heller, Legal TElegraphic Code (1925).

40. See Brown, supra note 39, at 601 n.3 (noting older lawyers' resistance to introduction of the typewriter). Louis Brown imagined partners in 19th-century law firms objecting to the use of the typewriter to prepare legal documents because "there were no cases in the books upholding the legal validity of documents prepared on a typewriter." $I d$. at 600 . For discussions of the shift from scribes and scriveners to typewriters, see William T. Braithwaite, How Is Technology Affecting the Practice and Profession of Law?, 22 TEX. TECH L. REV. 1113, 1120-21 (1991); Nazareth A.M. Pantaloni III, Legal Databases, Legal Epistemology, and the Legal Order, 86 L. LIBR. J. 679, 692-94 (1994).

41. See Wayne K. Hobson, Symbol of the New Profession: Emergence of the Large Law Firm, 1870-1915, in The New High Priests: Lawyers in Post-Civil War America 3, 10 (Gerald W. Gawalt ed., 1984) [hereinafter THE NEW High PRIESTS].

42. John Foster Dulles, Foreword to Arthur H. Dean, William Nelson Cromwell 1854-1948, at i, iii (1957).

43. See DEAN, supra note 42, at 28. Although the first New York City telephone exchange was created in 1878, the firm thought it incompatible with a law practice:

At first it was considered unprofessional for a lawyer to have a telephone. Some lawyers were also distrustful of the privacy afforded by the instrument. This distrust may possibly have been aggravated by the fact that at the time there was one central exchange called 'Law' for all lawyers in the boroughs of Manhattan and the Bronx.

$I d$. at 27-28. Other law firms similarly struggled with the logistics of the new technology. A law clerk at a large New York law firm recalled that when he entered the practice in 1887, there was only one telephone in the corner of the office:

[I]f anybody was not busy and the telephone rang, that person would get up and answer it. We had two floors and if the telephone rang for a person on the upper floor and a man was foolish enough to answer it it was just too bad, as he had to run up to the next floor to get the person wanted. No stenographers. There was only one man in the office that could write shorthand and he wasn't so good.

Robert M. LunNy, Kelley Drye \& WARREN, AN Informal History 1836-1984, at 82-83 (1985) (quoting Adrian Larkin); see also DILKS, supra note 4, at 7 (noting that the telephone did not come into use at Morgan, Lewis \& Bockius for more than a decade after its invention); 
Of all the Gilded Age lawyers who balked at the introduction of new machines into the practice of law, none typified this antipathy to technology more than Clarence Seward, the managing partner of what would later become Cravath, Swaine \& Moore. ${ }^{44}$ According to Cravath's official firm history, "Seward sought in vain to save the office from the machine, which was destroying the simplicity of American life." ${ }^{45}$ Seward's adamance about the intrusion of modern technology was so pronounced that he not only disliked the telephone, ${ }^{46}$ he even balked at the use of elevators. In a story so telling that it can only be apocryphal, one colleague described the time that Seward refused to take an elevator up four flights to a hearing in federal court and insisted instead on walking. When he finally arrived at the courtroom, Seward was reportedly so out of breath that the argument had to be cancelled and the case submitted on the briefs. ${ }^{47}$

Confirmed technophobes like Seward notwithstanding, the emergence of new business machines dramatically altered the practice of law in the Gilded Age, greatly facilitating the ability of growing law firms like Cravath to serve the needs of an expanding corporate world. ${ }^{48}$ But Clarence Seward's Luddite spirit still haunts the legal profession today, and it may manifest itself again as issues surrounding the use of computer technology come to the forefront of

Rest, supra note 39, at 309 n.1 (describing how a telephone was kept in the reception area by a New York firm only to show "how up to date the firm was").

44. Seward, the nephew of Lincoln's Secretary of State, became head of the firm before age 40 and led the firm from 1867 to 1897. See 1 Robert T. Swaine, The Cravath Firm AND ITS PREDECESSORS, 1819-1947, at 116-17 (1946).

45. Id. at 448 .

46. See id. As was the practice in the early days of the telephone, the firm installed one unit in the entrance hall, and by 1888 had installed a "telephone closet." Id. Nevertheless, Seward so disliked the invention that for several years he refused to answer the telephone. See id. at 448-49. By 1891, he had relented enough to permit the installation of telephones on the partners' desks. See id. at 449. Seward also resisted the use of typewriters for his correspondence, because "[h]e felt that the clients would resent the lack of personal attention to their business implied in sending them machine-made letters." Id. Swaine describes an elaborate ruse used by other lawyers in the firm to obtain a typewriter for the office without incurring Seward's ire. See id. at 449-50.

47. See id. at 448 .

48. See Lawrence M. Friedman, History of American Law 607 (2d ed. 1985) (describing how typewriters made traditional law clerks obsolete); Hobson, supra note 41, at 10 ("[T]he large firm utilized modern means of communication and modern forms of office organization. Indeed, it may be said that the telephone, the typewriter, and probably the female stenographer-typist made the proliferation of large law firms possible."). One lawyer reported at the time that these three developments "tripled a lawyer's productivity." $I d$. at 24 n.23 (citing THERON G. STRONG, LANDMARKS OF A LAWYER's LIFETIME 393 (1914)). 
professional consciousness. ${ }^{49}$ Bar opinions are likely to insist that lawyers give only generalized legal information over the Internet, but not offer specific legal advice, and lawyers who persist in providing online services are likely to be cautioned to avoid any commitment to a full professional relationship. ${ }^{50}$ It is not hard to imagine that some unlucky cyberlawyer will be the subject of disciplinary action and held out as an example to others, especially when so many online lawyers are apparently oblivious to their professional obligations. ${ }^{51}$ In a profession as risk-averse and technologically challenged as the legal profession, it will take very little to discourage many lawyers from expanding their online activities. ${ }^{52}$

There is, however, another path the legal profession could take. Rather than try to discourage online advice-giving, we could instead recognize the vast untapped potential of cyberspace to aid in resolving one of the bar's most intractable problems - the delivery of legal services to people ${ }^{53}$ who cannot otherwise afford them. ${ }^{54}$ Instead of

49. The philosophy of the Luddites, early 19th-century opponents of technology, may have new resonance in the Digital Age. In his provocative book, Kirkpatrick Sales has argued for a modern revival of the Luddites' objections to the destructive aspects of technology. See generally KirkPatrick Sales, Rebels Against the Future: The Luddites ANd Their War ON THE INDUSTRIAL REVOLUTION: LESSONS FOR THE COMPUTER AgE (1995).

50. Some suggest that the legal profession's objections to the innovations of cyberspace are largely self-protective. See, e.g., Paul D. Rheingold, The Web's Prying Eyes, AM. LAw., May 1997, at 38, 38 ("One is reminded of the efforts of religious leaders to stop the Gutenberg printing press in the fifteenth century. The church feared that easy dissemination of information to the masses would endanger its monopoly on information and undermine its point of view.").

51. Recent actions taken against online activity include the disbarment of a Tennessee attorney who was accused of having used "spam" to flood newsgroups with advertisements, and the pending Texas probe into the sale of legal self-help books online by Nolo Press. See Tennessee Disciplines Lawyer for Internet E-Mail Campaign, 13 Laws. Man. on Prof. Conduct (ABA/BNA), (July 23, 1997), at 218, 218; Rinat Fried, Texas vs. Publisher: Are Books Lawyers?, NAT'L L.J., Apr. 6, 1998, at A4; Your Right to Use Self-Help Law Books and Software (visited Sept. 7, 1999) <http://www.nolopress.com/texas/rights.html> (on file with the Duke Law Journal).

52. See Kuester, supra note 29, at B11 ("As more restrictive ethical rules start appearing around the country, more attorneys will be deterred from diving into the cyberpool, and still others-especially those in larger, more conservative firms-are likely to get out of the water.").

53. My recommendations are most relevant for middle-income people because those in lower income brackets are unlikely today to have access to a personal computer or the requisite training to use the Internet, and so it is at best impractical to recommend online advice-giving as a solution to their legal needs. When computers become as affordable and as easy to operate as television sets, and when there is universal access to the Internet, the potential for using cyberspace as a medium for delivering low-cost legal services will be substantially enhanced. 
stressing the use of disclaimers, the bar could encourage lawyers to take seriously their ethical obligations in cyberspace and to embrace, rather than to reject, the creation of attorney-client relationships in nontraditional ways. By doing so, lawyers might be able to provide assistance to far more people than they currently reach by more traditional methods. Although part of this process will require educating lawyers about cyberspace, it will be even more important for the bar to reach some consensus on whether the traditional model of fullfledged attorney-client relationships should be rethought. The time may be ripe for renewed consideration of whether "unbundling" legal services, also known as "discrete task representation," would provide a more effective model for lawyers in the twenty-first century to use in providing the kind of limited legal help many average people need but cannot afford.

The final piece of this puzzle is for the growing community of legal ethics scholars to focus its considerable energies on examining the ethical implications of cyberspace practice. The statement of William Eldridge that begins this Article ${ }^{55}$ remains as fitting today as it was thirty-six years ago. Those in the field of legal ethics have not yet begun to grapple with the challenges posed to law practice by the Digital Age, and the time to do so is now, before those issues overtake us. This Article begins the dialogue.

54. See generally AMERICAN BAR AsSOCIATION CONSORTIUM ON LEGAL SERVICES AND the Public, Agenda for ACCess: The American People AND Civil Justice 4 (1996):

The two most important general findings from the CLNS [Comprehensive Legal Needs Survey] are that approximately half of all low- and moderate-income households in the survey reported facing some situation that raised a civil legal issue and yet that most of these situations were not brought to the system of justice.

Recent contributions to the debate over unmet legal needs include Talbot D'Alemberte, Tributaries of Justice: The Search for Full Access, 25 FLA. ST. U. L. REV. 631 (1998), which discusses means by which indigent persons can access the legal system, and Steven Lubet \& Cathryn Stewart, A "Public Assets" Theory of Lawyers' Pro Bono Obligations, 145 U. PenN. L. REV. 1245 (1997), which discusses a new theory of why lawyers should be required to perform pro bono service. Among the solutions that have been raised are programs for mandatory pro bono service, alternative dispute resolution, subsidized legal services, and the lessening of restrictions on non-lawyers providing some legal services. For general discussions of these issues, see GeOfFrey HaZARD ET AL., The LAW AND ETHics OF LAWYERING 1063-71 (2d ed. 1994) (describing how the poor often have unserved legal needs); DEBORAH L. RHODE \& DAVID LUBAN, LEGAL ETHICS 711-809 (2d ed. 1995) (examining the distribution of legal services in the United States).

55. See supra note 1 and accompanying text. 


\section{FORMING AN ATTORNEY-CLIENT RELATIONSHIP BY GIVING LEGAL ADVICE}

In order to understand the implications of giving legal advice online, we must first examine the common law governing the creation of attorney-client relationships. Scholars have devoted little work to this specific issue, ${ }^{56}$ perhaps because in most situations no one disputes the existence of the relationship. Nevertheless, a showing that an attorney-client relationship exists is a fundamental aspect of many areas of law, including claims of legal malpractice, conflicts of interest, attorney-client privilege, and unauthorized practice of law. ${ }^{57}$ The specific question before us is whether giving legal advice can suffice to create an attorney-client relationship. ${ }^{58}$

The most recent analysis of the formation of an attorney-client relationship is found in the Restatement (Third) of the Law Governing Lawyers, approved by the American Law Institute ("ALI") in early $1998 .^{59}$ Section 26 of the Restatement outlines the principles governing the formation of the attorney-client relationship as follows:

A relationship of client and lawyer arises when:

(1) a person manifests to a lawyer the person's intent that the lawyer provide legal services for the person; and either (a) the lawyer manifests to the person consent to do so; or (b) the lawyer fails to manifest lack of consent to do so, and the lawyer knows or reasonably

56. The most comprehensive treatment of this issue is found in Ronald Friedman, The Creation of the Attorney-Client Relationship: An Emerging View, 22 CAL. W. L. REv. 209 (1986).

\section{See id. at 209-10:}

Although the question of whether or not an attorney-client relationship exists may arise in a variety of contexts, there are basically six situations in which the provable existence of an attorney-client relationship takes on significance. These six are: the legal malpractice lawsuit; the client's attempt to be compensated from a clients' security fund; the attorney's attempt to claim an attorney's lien; the attempt by a third party to establish the attorney's authority, actual or apparent, to bind the client; the petition to appropriate authorities to have the attorney disciplined; and, evidentiary matters relating to the attorney-client privilege.

58. See Carol A. Needham, Splitting Bar Admission into Federal and State Components: National Admission for Advice on Federal Law, 45 U. KAN. L. REV. 453, 461 (1997) ("Giving a client legal advice tailored to the specific facts presented by that client is at the heart of the definition of the practice of law.").

59. See Restatement on Lawyers Completed With Final ALI Approval of All Sections, 66 U.S.L.W. 2716 (May 26, 1998). For an overview of the Restatement, see the series of symposium articles in 10 GeO. J. LEGAL ETHICS 541, 541-789 (1997). 
should know that the person reasonably relies on the lawyer to provide the services. ${ }^{60}$

The Restatement thus contemplates that the attorney-client relationship arises either by consent of both parties, or under an estoppel theory, where the putative client reasonably has relied on the lawyer to perform legal services. ${ }^{61}$ The Restatement's approach generally is to treat the relationship as a product of contract law. ${ }^{62}$

As I shall show in this part, the online posting of a specific legal question by a layperson manifests the intent to have a lawyer perform legal services-specifically, to provide legal advice. The lawyer can manifest consent to perform legal services in a number of ways. Most simply, he can post a public message or send a private e-mail message to the putative client expressly stating his consent to give the legal advice. The lawyer can also manifest consent by performance-that is, by providing the requested legal advice. Moreover, even if the lawyer does not wish to enter into a professional relationship with the online questioner, furnishing specific legal advice in response to the question, without more, can constitute consent regardless of the lawyer's subjective intent. Indeed, under part (b) of the Restatement test

60. Restatement (ThiRd) OF THE LAW Governing LAWyers $§ 26$ (Proposed Final Draft No. 1, 1996) [hereinafter Restatement (Proposed Final Draft No. 1)].

61. The ABA's Model Rules of Professional Conduct do not specifically address the formation of the attorney-client relationship. Rather, in a preliminary section entitled "Scope," the Model Rules provide:

[F]or purposes of determining the lawyer's authority and responsibility, principles of substantive law external to these Rules determine whether a client-lawyer relationship exists. Most of the duties flowing from the client-lawyer relationship attach only after the client has requested the lawyer to render legal services and the lawyer has agreed to do so. But there are some duties, such as that of confidentiality under Rule 1.6, that may attach when the lawyer agrees to consider whether a client-lawyer relationship shall be established. Whether a client-lawyer relationship exists for any specific purpose can depend on the circumstances and may be a question of fact.

Model Rules of Professional Conduct Preamble para. 15 (1998). Some jurisdictions have defined the relationship by statute. See CAL. EvID. CODE $§ 951$ (West 1998) (defining client as "a person who ... consults a lawyer for the purpose of retaining the lawyer or securing legal service or advice from him in his professional capacity").

62. This is the traditional approach. See Friedman, supra note 56, at 213 ("[T]he starting point of analysis in the creation of an attorney-client relationship is the law of contract."). For another overview of this area, see David N. May, Note, Inhouse Defenders of Insureds: Some Ethical Considerations, 46 DRAKE L. REV. 881, 905-10 (1998). An oft-cited definition is that in Kurtenbach v. TeKippe, 260 N.W.2d 53, 56 (Iowa 1977): "The relationship is created when (1) a person seeks advice or assistance from an attorney, (2) the advice or assistance sought pertains to matters within the attorney's professional competence, and (3) the attorney expressly or impliedly agrees to give or actually gives the desired advice or assistance." 
described above, a lawyer posting such advice online without disclaiming any intent to create an attorney-client relationship could still incur the obligations of a professional relationship if the lawyer knows or reasonably should know that the questioner is reasonably relying on the lawyer's advice. Most importantly, a careful examination of the law suggests that the attorney-client relationship cannot easily be disclaimed and that, under certain circumstances, even an explicit disclaimer may not suffice to shield an online lawyer from potential liability for the legal advice given.

The Restatement's explanation of how attorney-client relationships are formed is consistent with the substantial body of case law addressing this issue. A closer examination of the contours of that law is essential to understanding the potential perils of online advicegiving. I shall examine each aspect of the Restatement test in turn.

\section{A. The Client Manifests an Intent to Receive Legal Services}

Under what circumstances may a request for legal advice constitute the first step in the formation of an attorney-client relationship? In the traditional setting of a lawyer's office, there is little mystery about this aspect of the formation of a professional relationship. The layperson comes to the office of the lawyer and expressly asks the lawyer to perform legal services, most commonly by describing a set of facts and asking either for specific legal advice or for the lawyer's assistance in accomplishing a particular objective. ${ }^{63} \mathrm{~A}$ request for legal advice standing alone may suffice to manifest the intent to receive legal services. Well-established principles hold that there need be no written contract and that payment of a fee is not a prerequisite to finding a professional relationship, although such a fee will be a strong indication that such a relationship existed. ${ }^{64}$

63. See Restatement (Proposed Final Draft No. 1), supra note $60, \S 26 \mathrm{cmt}$. c:

A client's manifestation of intent that a lawyer provide legal services to the client may be explicit, as when the client requests the lawyer to write a will. The client's intent may be manifest from surrounding facts and circumstances, as when the client discusses the possibility of representation with the lawyer and then sends the lawyer relevant papers or a retainer requested by the lawyer.

64. See, e.g., Westinghouse Elec. Corp. v. Kerr-McGee Corp., 580 F.2d 1311, 1317 (7th Cir. 1978) (holding that an attorney-client relationship need not be based on a formal contract and that it may arise even if no fees are paid); Green v. Montgomery County, 784 F. Supp. 841, 845 (M.D. Ala. 1992) (finding payment of legal fees may be evidence of an attorney-client relationship); Keoseian v. Von Kalkbach, 707 F. Supp. 150, 152 (S.D.N.Y. 1989) ("[The] defendant has found no case, nor has this Court, where a person who signed a retainer agreement was never- 
Perhaps the best-known cautionary tale for treating a layperson's request for legal advice as the first step in forming an attorneyclient relationship is Togstad v. Vesely, Otto, Miller \& Keefe, ${ }^{65} \mathrm{de}-$ cided by the Minnesota Supreme Court in 1980. Togstad's notoriety in legal ethics circles stems largely from its broad reading of how an attorney-client relationship may inadvertently be created, and it thus merits careful consideration here. Joan Togstad, the wife of a patient who had suffered a stroke after surgery, met with attorney Jerre Miller regarding her husband's condition about fourteen months after the hospitalization had begun, believing that she might have a case for medical malpractice. ${ }^{66}$ She told Miller what had happened at the hospital, and Miller took notes and asked questions during the meeting, which lasted between forty-five minutes and an hour. ${ }^{67} \mathrm{At}$ the end of the appointment, Miller told Mrs. Togstad that "he did not think [they] had a legal case, [sic] however, he was going to discuss this with his partner." ${ }^{68}$ Mrs. Togstad understood that Miller would call her if he changed his mind. ${ }^{69}$ Miller never called her, never discussed fee arrangements, never authorized the receipt of medical records, and never billed for the interview. ${ }^{70}$ Most significant, however, is the fact that, according to Mrs. Togstad, Miller never informed her

theless found not to be a client."); In re Johore Inv. Co., 49 B.R. 710, 713 (Bankr. D. Haw. 1985) ("[E]stablishment of attorney-client relationship [is not] dependent on fees paid . . . An attorney-client relationship can exist even if services are rendered gratis." (citations omitted)); Foulke v. Knuck, 784 P.2d 723, 726 (Ariz. Ct. App. 1989) ("Although it is not necessary for [an] individual to pay the attorney a fee for the services rendered in order for [a] relationship to be established . . . payment for legal services ... is persuasive evidence that an attorney-client relationship was established." (citation omitted)); Gillespie v. Klein, 406 N.W.2d 547, 556 (Minn. Ct. App. 1987) ("To the ordinary person, even one knowledgeable in business, receipt of an attorney's bill is usually a reasonable sign that the attorney feels he performed legal services based on an attorney-client relationship."); cf. Kubin v. Miller, 801 F. Supp. 1101, 1115 (S.D.N.Y. 1992) ("[A]lthough a fee arrangement is not necessary for establishment of an attorney-client relationship, the absence of such arrangement can be an indication that [an] attorney-client relationship never existed.”). See generally May, supra note 62, at 907 n.183 (1998) (collecting cases where payment of a legal fee was found to be evidence of an attorney-client relationship).

65. 291 N.W.2d 686 (Minn. 1980) (per curiam).

66. See id. at 690. The appointment had been made for her by her husband's former supervisor, who also accompanied her to the meeting. See id.

67. See id.

68. Id.

69. See id. Miller disputed the nature of this conversation, asserting that he had told her that "there was nothing related in her factual circumstances that told [him] that she had a case that [his] firm would be interested in undertaking," and that he had told her that he would call back only if his partner disagreed with his view of the case. Id. at 691.

70. See id. at 690. 
that he had no expertise in medical malpractice, never suggested that she see another lawyer, and never mentioned that the statute of limitations on her claim was only two years. ${ }^{71}$

A year later, Joan Togstad consulted another lawyer, but by then the statute of limitations had expired. ${ }^{72}$ She sued Miller and his firm for legal malpractice, claiming that she had been given a "qualified, quality legal opinion that [she and her husband] did not have a malpractice case." ${ }^{, 73}$ The jury ultimately found that there had been an attorney-client relationship and that Miller was liable for malpractice in the amount of nearly $\$ 650,000 .^{74}$ On appeal, the court addressed the question of whether the conversation between Togstad and Miller had given rise to an attorney-client relationship. The court explained that the issue could be resolved under either a contract or a tort theory. ${ }^{75}$ According to the court, the jury could have found on this evidence that "[the putative client] sought and received legal advice from [the lawyer] under circumstances which made it reasonably foreseeable to [the lawyer] that [the putative client] would be injured if the advice were negligently given." 76 In particular, Mrs. Togstad "went to Miller for legal advice, was told there wasn't a case, and relied upon this advice in failing to pursue the claim for medical malpractice." 77

Although not universally accepted, ${ }^{78}$ Togstad has stood for two decades as a warning to law students and lawyers about the dangers

71. See id. Miller again disputed Mrs. Togstad's account. He testified that he had told her his firm was not expert in the area of medical malpractice and had encouraged her to consult another lawyer. See id. at 691.

72. See id. at 690.

73. Id. at 691 (alteration in original). Although he disputed whether he had furnished "advice," Miller conceded at trial that "she was seeking [his] opinion as an attorney in the sense of whether or not there was a case that the firm would be interested in undertaking." Id.

74. See id. at 692.

75. See id. at 693. According to the court, applying negligence principles to these facts would require a showing that the "defendant rendered legal advice (not necessarily at someone's request) under circumstances which made it reasonably foreseeable to the attorney that if such advice was rendered negligently, the individual receiving the advice might be injured thereby." Id. at 693 n.4. In contrast, using a contract theory would require "the rendering of legal advice pursuant to another's request and the reliance factor, in this case, where the advice was not paid for, [would] need [to] be shown in the form of promissory estoppel." Id.

76. Id. at 693 .

77. $I d$.

78. See, e.g., Comment, Attorney Malpractice: Use of Contract Analysis to Determine the Existence of an Attorney-Client Relationship, 63 MINN. L. REV. 751, 759 (1979) (criticizing Togstad). Much of the criticism has focused on the fact that Togstad does not rely on an express or 
of providing off-the-cuff legal advice. ${ }^{79}$ Togstad suggests that a request for legal advice about the merits of a particular claim may readily suffice to begin the process of forming an attorney-client relationship. Indeed, the issue of creating obligations in attorneys from initial consultations has become increasingly prominent in recent years, and more courts appear willing to treat a request for legal advice as the beginning of an attorney-client relationship, even if the parties never formally agree upon representation. ${ }^{80}$

implied contract to impose liability and thus leaves the precise source of the attorney-client relationship ambiguous. One critic asserted:

The contract approach is not a useful analytical tool for determining the existence of an attorney-client relationship because a lawyer's duty to exercise reasonable care in giving professional advice frequently does not arise from contract, but from the position the lawyer occupies as an expert in legal matters. Because of his assumed expertise, the lawyer is in a unique position to cause harm if he gives erroneous legal advice to a person who has consulted him.

Id. at 758. Only a few Minnesota cases have actually applied Togstad's holding, although the case is often cited by other courts as well. In Veit v. Anderson, 428 N.W.2d 429 (Minn. 1988), the plaintiff had previously consulted the lawyer on other legal matters, but the lawyer had told him that he did not wish to represent him in a pending real estate deal. See id. at 432. Nevertheless, the plaintiff alleged that, in the course of assisting the plaintiff in the real estate transaction, the lawyer had given him erroneous legal advice about the effect of signing a certain document. See id. at 431. The court held that there was a genuine issue of material fact as to whether an attorney-client relationship had been created, as it arguably was reasonable for the plaintiff to rely on the lawyer's representations. See id. The court explained: "If [the lawyer] did advise [the plaintiff] on the legal effect of the agreement, he may have established an attorneyclient relationship with [the lawyer]." Id. at 432; see also Langeland v. Farmers State Bank, 319 N.W.2d 26, 30 (Minn. 1982) ("[T] he relationship is created whenever a person seeks and receives legal advice from a lawyer under circumstances in which a reasonable person would rely on the advice."); TJD Dissolution Corp. v. Savoie Supply Co., 460 N.W.2d 59, 62 (Minn. Ct. App. 1990) (defining the tort theory of attorney-client relationships as one which "protects lay people where it would be reasonably foreseeable to the lawyer that the person might be injured if the advice is given negligently" (citing Togstad, 291 N.W.2d at 693 n.4)).

79. The case is cited in many legal ethics textbooks. See, e.g., STEPHEN GILLERS, REgUlATION OF LAWYERS: PROBLEMS OF LAW \& ETHICS 677-85 (4th ed. 1995); HAZARD ET AL., supra note 54, at 481-87.

80. See, e.g., Green v. Montgomery County, 784 F. Supp 841, 845 (describing "a small, but growing, body of law and commentary which has attempted to address the circumstances under which an initial consultation between a prospective client and an attorney could be viewed as having developed into an attorney-client relationship"). See generally ABA Comm. on Ethics and Professional Responsibility, Formal Op. 90-358 (1990) (noting that the duty of confidentiality for information derived from preliminary consultation arises under rules of ethics, the law of agency, and the law of evidence, and that the duty persists even if no formal attorney-client relationship is established); Debra Bassett Perschbacher \& Rex R. Perschbacher, Enter at Your Own Risk: The Initial Consultation \& Conflicts of Interest, 3 GEO. J. LeGAL ETHICs 689, 701-05 (1990) (discussing situations in which an attorney-client relationship can arise without formal agreement by both parties); John Casey Pipes, The Implied Professional Relationship: An Extension of the Attorney's Duties and Obligations, 20 J. LEGAL Prof. 319 (1996) (examining ar- 
Today, a case like Togstad could easily arise online instead of in a traditional office visit. The question-and-answer from Dear Esquire that we reviewed earlier is reminiscent of Togstad, in that the questioner described a potential negligence action and the lawyer told the questioner that he had no viable legal claim. ${ }^{81}$ But how similar are the two situations? Posting a request for legal advice on the Internet is different in many ways from an office visit. Most obviously, a request posted online generally is not targeted at a particular attorney, but rather at a broad audience of lawyers, in the hope of receiving a response from one of them. In addition, one might argue that exchanges online lack the formality and face-to-face interaction of the traditional office visit. An examination of the case law, however, reveals that the courts have at times found a viable request for legal services in circumstances far less formal than those in Togstad. A request for legal advice may be found even when the exchange between lawyer and client was brief, ${ }^{82}$ or when the lawyer and putative client never met in person. ${ }^{83}$

eas in which the courts have extended some aspects of the attorney-client relationship to situations in which an attorney did not represent a client in the traditional sense).

81. See supra note 15 and accompanying text.

82. See In re Johore, 49 B.R. 710,714 (Bankr. D. Haw. 1985) (finding a single, 90-minute consultation in which confidential information was disclosed sufficient to establish an attorneyclient relationship); Herbes v. Graham, 536 N.E.2d 164, 165 (Ill. App. Ct. 1989) (finding an attorney-client relationship after a single 90-minute discussion of possible representation); King v. King, 367 N.E.2d 1358, 1360 (Ill. App. Ct. 1977) (finding an attorney-client relationship after a client had a single confidential meeting of 30 minutes with an attorney); Intercapital Corp. v. Intercapital Corp., 700 P.2d 1213, 1215 (Wash. Ct. App. 1985) (finding a two-hour preliminary discussion in confidence sufficient to create an attorney-client relationship); $c f$. Seeley v. Seeley, 514 N.Y.S.2d 110, 112 (App. Div. 1987) (holding that after a single office visit of 90 minutes, "no formal attorney-client relationship resulted, [but] the foregoing facts establish[ed] that a fiduciary obligation nevertheless arose with respect to the matters discussed at the conferences").

83. See Green v. Montgomery County, 784 F. Supp. 841, 844 (M.D. Ala. 1992) (finding a de facto attorney-client relationship sufficient to disqualify an attorney who had previously represented a client in another matter after that attorney had a single phone conversation about possible further representation with the client); Jacobson v. Pitman-Moore, Inc., 624 F. Supp. 937, 942 (D. Minn. 1985) (finding that legal advice over the telephone about a statute of limitations is evidence of an attorney-client relationship); Bays v. Theran, 639 N.E.2d 720, 723 (Mass. 1994) (finding an attorney-client relationship from a legal consultation conducted solely by mail and telephone); DeVaux v. American Home Assurance Co., 444 N.E.2d 355, 357 (Mass. 1983) (finding that an attorney-client relationship may have arisen from telephone discussions between a lawyer's secretary and the putative client). But cf. David B. Lilly, Co. v. Fisher, 799 F. Supp. 1562, 1568 n.7 (D. Del. 1992) (finding that unconfirmed telephone calls, with no documentation that legal advice was given, were insufficient to establish definitively an attorney-client relationship). 
Two cases are particularly noteworthy in considering the contours of a putative client's request for legal advice. In Foulke $v$. $K n u c k,{ }^{84}$ a lawyer seeking to divorce his wife met with another lawyer to discuss legal issues surrounding the divorce and questions involving child custody. ${ }^{85} \mathrm{He}$ paid the lawyer for this meeting but did not retain her to represent him in the divorce. ${ }^{86}$ The second lawyer later sought to represent the wife in the divorce proceedings, claiming that she had never undertaken to represent Foulke as a client. ${ }^{87}$ The court disagreed, stating that the existence of an attorney-client relationship "is proved by showing that the party sought and received advice and assistance from the attorney in matters pertinent to the legal profession." ${ }^{88}$ Moreover, the court rejected the contention that this meeting simply constituted a "sharing of legal information." "The court explained that " $[\mathrm{w}]$ hether one seeks legal information or legal advice from an attorney, the attorney is being consulted for his or her professional, legal expertise."

The second case is Todd $v$. State of Nevada, ${ }^{91}$ in which an attorney had been visiting a client in prison when another inmate handed him a written account of the facts surrounding his own imprisonment. $^{92}$ The court held that the letter was subject to the attorneyclient privilege because the inmate had sought the lawyer's advice on matters that were within his professional competence and the lawyer's acceptance of the letter was an implied agreement to render the advice sought. ${ }^{93}$ The Todd court stated that "[a]bsent a written contract for services, we can envision no clearer facts which would establish an attorney-client relationship." ${ }^{94}$

84. 784 P.2d 723 (Ariz. Ct. App. 1989).

85. See id. at 725 .

86. See id.

87. See id.

88. Id. at 726. The court further noted: "The fact that a consultation is relatively brief does not negate the establishment of an attorney-client relationship." Id.

89. Id.

90. Id.; see also King v. King, 367 N.E.2d 1358 (Ill. App. Ct. 1977) (finding an attorneyclient relationship where a half-hour meeting between a husband and an attorney to discuss an imminent divorce was for the purpose of obtaining professional legal advice and confidential information was disclosed to facilitate such advice).

91. 931 P.2d 721 (Nev. 1997).

92. See id. at $723-24$.

93. See id. at 725 .

94. Id.; see also In re Lieber, 442 A.2d 153, 155 (D.C. 1982) (finding an implied attorneyclient relationship after a lawyer voluntarily placed his name on a roster to assist inmates in pro 
These cases indicate that a request for legal advice may easily begin the process, even in apparently casual situations, of creating a professional relationship. In light of these cases, the legal queries posted in newsgroups, in chat rooms, and on various websites would seem to fit easily into the framework created by this precedent. One might counter, however, that a critical distinction between requests for specific legal advice such as those in Togstad, Foulke, and Todd, and similar requests online, is that postings in newsgroups and chat rooms are made openly, rather than in confidence. ${ }^{95}$ Online lawyers might argue that a layperson who truly expects legal advice will present his legal problem in confidence and will expect a confidential reply.

What may appear intuitive to lawyers may not be so obvious to laypeople, particularly those who believe that they have no other recourse for obtaining legal advice. The Restatement does not require that the desire to obtain legal services be expressed in confidence, nor does it state that confidential information must be conveyed to the lawyer in order for a relationship to arise. Indeed, as Parts II and III will show, the bar's historical warnings against giving specific advice in public settings such as radio talk shows and seminars have been based on the assumption that laypeople are likely to rely on such advice. Moreover, a client or prospective client may always choose to waive the duty of confidentiality. ${ }^{96}$ Communicating confidential information to a lawyer is often powerful evidence of the intent to form a professional relationship. It often may impose duties on a lawyer even if the representation is declined, but it does not appear to be a required aspect of the client's request for legal services. ${ }^{97}$

se civil actions and was assigned to an inmate). But cf. United States v. Weinstein, 511 F.2d 622, 628 (2d Cir. 1975) (declining to infer an attorney-client relationship where a district court judge had appointed as counsel for fugitive defendants an attorney who had neither known about nor consented to the appointment).

95. This distinction is less pertinent to questions that are e-mailed directly to an attorney's website, because these questions ordinarily are not visible to anyone other than the recipient. Confidentiality issues about e-mail security and ethical obligations regarding encryption may arise, but for our discussion they do not affect the outcome.

96. See generally Model Rules of Professional Conduct Rule 1.6 (1998) (defining parameters of confidentiality of information in attorney-client relationships).

97. This is not to suggest that the confidentiality of the information is irrelevant to the determination of whether a relationship existed. In conflict of interest cases, for example, some courts have determined that the information furnished by the putative client in the initial consultation was insufficiently confidential to merit disqualification. Perhaps the best known example of this approach is Mailer v. Mailer, 455 N.E.2d 1210 (Mass. 1983). In that case, the court declined to order disqualification of a lawyer after an initial one-hour consultation with the es- 
Thus, a request for legal advice that appears on a bulletin board or in a chat group, accessible to anyone with a Web browser, may suffice under existing case law to start the process of forming an attorneyclient relationship, even though it is not "confidential."

One might also argue that online requests for legal advice are insufficiently formal to trigger an attorney-client relationship and that they should be treated instead as the cyberspace equivalents of socalled cocktail party questions. The notion that a legal question posed to a lawyer in a social setting does not amount to a request for legal advice is not a new one, ${ }^{98}$ and the Restatement rather offhandedly announces in the comments to section 26 that "a lawyer may answer a general question about the law, for example in a purely social setting, without a client-lawyer relationship arising." 99 The rationale is not explained, nor is a case cited for this proposition.

At least two possible rationales in support of this comment suggest themselves. The first is that a "general question about the law" is not a request for legal services. This distinction becomes critical as we review the bar's historical regulation of legal advice-giving, which always has attempted to draw a sharp distinction between general legal

tranged wife of author Norman Mailer, even though she had furnished some information and filled out a client history form. See id. at 1213. Noting that the question was "close," the court nevertheless permitted the lawyer to represent Norman Mailer in the divorce because the information disclosed was on the public record and was not "intimate," cautioning that this "probably brings us as close to the outer limits as we shall want to go." Id. The case seems inconsistent with more modern approaches to conflicts of interest that have emerged since the Model Rules, and even in Massachusetts the case has been limited. See, e.g., DeLoury v. DeLoury, 495 N.E.2d 888 (Mass. App. Ct. 1986) (disqualifying an attorney after a one-hour consultation in which the lawyer prepared an intake form, the putative client disclosed family history and financial matters, as well as intimate details, and the lawyer gave some preliminary advice about Massachusetts law). Nevertheless, there is similar precedent in other jurisdictions. See, e.g., Derrickson v. Derrickson, 541 A.2d 149, 151 (D.C. 1988) (holding that no attorneyclient relationship arose between an attorney and a client who had met for a brief consultation eight years prior to the present case, where the consultation involved no sharing of confidential information).

98. See Charles W. Wolfram, Modern Legal Ethics § 5.6.2, at 210 n.54 (1986):

Courts have drawn a line of sorts between instances of casual, friendly, or social conversation, where no liability should arise, and more formal and serious occasions on which the lawyer could reasonably be understood to be applying or undertaking to apply the skills of a lawyer for the benefit of a client.

See also Friedman, supra note 56, at 217-25 (discussing nontraditional means of creating attorney-client relationships).

99. Restatement (Proposed Final Draft No. 1), supra note 60, $\$ 26 \mathrm{cmt}$. c; accord Franko v. Mitchell, 762 P.2d 1345, 1360 (Ariz. Ct. App. 1988) (Grant, J., concurring in part and dissenting in part) ("Obviously, specific advice given to an unrepresented party in a formal office setting carries more weight than general advice given at a cocktail party."). 
information and specific legal advice. The second possible support for this conclusion is that a lawyer would not reasonably expect a questioner to rely on information furnished in a casual social setting and that it would not be reasonable for a questioner so to rely.

These theories do not entirely resolve the issue, in the context of either a cocktail party conversation or an Internet exchange. One may readily envisage a scenario in a social setting in which someone wants specific legal advice from a lawyer and indicates that she will rely on the advice. At a party, a casual acquaintance might describe his termination from a job to an employment law specialist, for example, and ask her whether he should file a lawsuit. In response to the employment law question, an unwary lawyer could well provide sufficiently detailed advice, tailored to the questioner's individual facts, of the sort she would provide in an office setting. There is no guarantee that she could later avoid a lawsuit for malpractice on the ground that she gave such advice at a cocktail party rather than in her office. Indeed, even in the absence of precedent holding a lawyer liable for cocktail party pontifications, legal ethics professors regularly have cautioned their students against precisely such behavior. ${ }^{100} \mathrm{Sim}-$ ply dismissing Internet exchanges as the cyberspace equivalent of social banter will not resolve this issue. ${ }^{101}$ Moreover, the formality requisite for reasonable reliance may vary among settings. What might be unreasonable reliance in a social setting might well be reasonable in the environment of cyberspace, where individuals are more prone to seek attorneys out rather than happen upon them accidentally.

This review of what constitutes a request for legal services reflects that the courts have been willing to construe this element broadly, and nothing suggests that the courts will take a different approach with respect to similar requests occurring in cyberspace. Indeed, a case could be made that courts ought to be particularly protective of laypeople who seek legal advice online. Most lay questioners who post specific information about their legal problems and ask

100. See, e.g., Richard A. Zitrin \& CAROL M. LANGFord, Legal Ethics IN THE PRACTICE OF LAW 28 (1995) (proposing a hypothetical suggesting that a lawyer who gives advice at a cocktail party could inadvertently create an attorney-client relationship).

101. This is not to say that the informality of a particular exchange is irrelevant to the determination of whether an attorney-client relationship was created. See, e.g., Farmer v. Mount Vernon Realty, Inc., 720 F. Supp. 223, 225 (D.D.C. 1989) (finding that "informal conversation [between an attorney and a client], without any additional contact between the two parties, cannot establish an attorney-client relationship ... . At best, the conversation . . . was a preliminary step to the establishment of an attorney-client relationship."). 
for help expect that they will be able to rely on the answer they receive. Posting legal questions would otherwise seem to be a futile exercise. Even a cursory review of the postings to websites like Dear Esquire shows a disturbingly large number of laypeople with pressing legal problems who believe they have no other way to find help. The level of detail supplied in many of these questions indicates that the average questioner is not asking for legal information out of idle curiosity or academic interest. Rather, these questioners need legal advice, and they expect that they will receive it. What happens when they do receive it is the subject of the next section.

\section{B. The Lawyer Manifests Consent to Provide Legal Services}

The second aspect of forming an attorney-client relationship is the lawyer's consent to provide legal services. In a traditional office setting, there is little ambiguity about this prong as well. As comment e to section 26 of the Restatement explains: "The lawyer may explicitly agree to represent the client or may indicate consent by action, for example by performing services requested by the client." ${ }^{, 102}$ Although the agreement is ordinarily embodied in an oral or written agreement with respect to fees, it need not be. In an online exchange, for instance, a lawyer could explicitly consent to represent the putative client by posting a response or by sending an individual e-mail directly to the questioner that says, "I will represent you in this matter."

The more important question is whether providing the requested legal advice, without specifically agreeing to enter into a professional relationship, also suffices as consent. The Restatement clearly supports this approach, using the following illustration:

Client telephones Lawyer, who has previously represented Client, stating that Client wishes Lawyer to handle a pending antitrust investigation, and asking Lawyer to come to Client's headquarters to explore the appropriate strategy for Client to follow. Lawyer comes to the headquarters and spends a day discussing strategy, without stating then or promptly thereafter that Lawyer has not yet decided whether to represent Client. Lawyer has communicated willingness to represent Client by so doing. Had Client simply asked Lawyer to

102. Restatement (Proposed Final Draft No. 1), supra note $60, \S 26 \mathrm{cmt}$. e. 
discuss the possibility of representing Client, no client-lawyer relationship would result. ${ }^{103}$

A number of cases also have held that providing specific legal advice in response to a request for such assistance forms an attorneyclient relationship. ${ }^{104}$ Indeed, even giving legal advice in less formal situations, such as when a lawyer advises a pro se litigant, may suffice to create professional obligations. ${ }^{105}$

103. Id. illus. 1 .

104. See Waggoner v. Snow, Becker, Kroll, Klaris \& Krauss, 991 F.2d 1501, 1505 (9th Cir. 1993) ("[A]n attorney-client relationship is formed when an attorney renders advice directly to a client who has consulted with him seeking legal counsel." (citations omitted)); In re United Utensils, 141 B.R. 306, 309 (Bankr. W.D. Pa. 1992) (finding that a corporate lawyer who gave personal legal advice to an individual connected with a corporation may have created a conflict of interest); Davis v. State Bar, 655 P.2d 1276, 1279 (Cal. 1983) (finding an attorney-client relationship from evidence of ongoing consultations between an attorney and a client); King v. King, 367 N.E.2d 1358, 1360 (Ill. App. Ct. 1997) (finding an attorney-client relationship after an initial consultation meeting); Herbes v. Graham, 536 N.E. 2d 164, 168 (Ill. App. Ct. 1989) ("If the client consults the attorney for the evident purpose of securing legal advice, an attorneyclient relationship will probably be found regardless of the attorney's intent or the fact that a further relationship did not develop as a result of the primary consultation."); DeVaux v. American Home Assurance Co., 444 N.E.2d 355, 358 (Mass. 1983) (finding a possible attorneyclient relationship where a lawyer's secretary told the client to send a letter and arranged a medical exam on her behalf); Admiral Merchants Motor Freight v. O'Connor \& Hannan, 494 N.W.2d 261, 266 (Minn. 1992) (holding that an attorney-client relationship can form "whenever an individual seeks and receives legal advice from an attorney in circumstances in which a reasonable person would rely on such advice"); Seeley v. Seeley, 514 N.Y.S.2d 110, 112 (App. Div. 1987) (finding meetings to discuss possible representation and legal matters sufficient to create fiduciary obligations similar to those of an attorney-client relationship); In re Bristow, 721 P.2d 437, 441 (Or. 1986) (finding an attorney-client relationship where a lawyer gave legal advice but did not formally represent the client); In re McGlothen, 663 P.3d 1330, 1334 (Wash. 1983) (finding an attorney-client relationship where a lawyer acted largely as an advisor and no express relationship was established); $c f$. Connelly v. Wolf, Block, Schorr \& Solis-Cohen, 463 F. Supp. 914, 919 (E.D. Pa. 1978) ("Although the relationship of attorney and client may be implied from the conduct of the parties, such conduct must evidence an offer or request by the client for legal services and an acceptance of the offer by the attorney."); Robert F. Housman, The Ethical Obligations of a Lawyer in a Political Campaign, 26 U. MEM. L. REV. 3, 42 (1995) (suggesting that lawyers should be wary when contacted by a political campaign for legal advice, because an attorney-client relationship could result).

105. See generally Helen B. Kim, Note, Legal Education for the Pro Se Litigant: A Step Toward a Meaningful Right to Be Heard, 96 YALE L.J. 1641, 1658-60 (1987) (suggesting that lawyers conducting classes for pro se litigants must disclaim an attorney-client relationship); Elizabeth J. Cohen, Afraid of Ghosts, A.B.A. J., Dec. 1997, at 80 (suggesting that assisting pro se litigants could create attorney-client relationships); $c f$. Russell Engler, Out of Sight and Out of Line: The Need for Regulation of Lawyer's Negotiations with Unrepresented Poor Persons, 85 CAL. L. REV. 79, 91-93 (1997) (arguing that Model Rule 4.3 bars giving legal advice to unrepresented persons and should be formally construed as such); Kathy Garner, Lawyer-Librarians in Public Law Schools: The Ethical Conundrums of Pro Bono Activities, 84 L. LIBR. J. 31, 58 (1992) ("Liability might also arise when a lawyer-librarian is helping a pro se patron. Even if 
Consider In re Raynard, ${ }^{106}$ a bankruptcy case in which a debtor, having been served with a summons and a complaint, called a law firm he had selected from the Yellow Pages to obtain an advertised "free telephone consultation." 107 The lawyer advised the debtor that he need not take any formal action in response to the complaint, advice that was erroneous and resulted in entry of a default judgment against the debtor. ${ }^{108}$ The debtor later tried to have the default set aside because of what he claimed to be the negligence of his attorney. He maintained: "I certainly did not deliberately fail to adequately explain the nature of the lawsuit to the attorney; in fact, I would not have call [sic] a lawyer if I had not been motivated to protect my interests." debtor was bound by the omissions of his attorneys, inasmuch as these limited contacts had sufficed to create an attorney-client relationship:

At least for the duration of Defendant's telephone conversation with the attorney at Clark, Washington \& Smith, an attorney-client relationship appears to have existed. An attorney-client relationship may be inferred if a party shows that the advice or assistance of an attorney is both sought and received in matters pertinent to the attorney's profession. Additionally, even where no express attorneyclient relationship exists, an attorney may be held liable for negligence if the attorney gratuitously undertakes to perform a legal service to another with the other's approval. ${ }^{110}$

It takes little imagination indeed to envision a similar claim arising from an online exchange. ${ }^{111}$ One might easily substitute the services

neither intends to create an attorney-client relationship, such a relationship could be inferred.").

106. 171 B.R. 699 (Bankr. N.D. Ga. 1994).

107. Id. at 700 .

108. See id.

109. Id.

110. Id. at 702 (citation omitted); see also Jacobson v. Pitman-Moore, Inc., 624 F. Supp. 937, 942-43 (D. Minn. 1985) (refusing to toll a statute of limitations when the plaintiff missed a deadline based on a brief meeting in which the lawyer had advised that the time limit did not apply, because "[i]f [the lawyer] believed that he was not acting as plaintiff's attorney, [the lawyer] logically would not have given plaintiff legal advice and would have clarified the fact that he was not representing plaintiff").

111. The Raynard case highlights the additional possibility that a court might use the theory of "gratuitous undertaking," in which a lawyer volunteers to perform a service for a nonclient, to impose liability for giving legal advice. See Raynard, 171 B.R. at 702. As one commentator notes: 
offered at a law firm's free website for the free telephone consultation at issue in In re Raynard.

Togstad also provides guidance in this regard. The lawyer in Togstad subjected himself to malpractice liability because he gave specific legal advice to someone who had requested such advice: he told Mrs. Togstad that she had no case, and in so doing, created a professional relationship with her. ${ }^{112}$ No fee was necessary, and the lawyer's subjective intent not to form a relationship was not determinative. ${ }^{113}$ The linchpin for the analysis was the giving of legal advice. ${ }^{114}$

The lawyer who offers gratuitous advice is in a position analogous to a physician who witnesses a traffic accident. The law does not impose a duty on physicians to treat a victim of the accident. Should the physician undertake to treat a victim, however, he will be liable if he does so negligently. Similarly, if a lawyer voluntarily offers legal advice to an individual, an attorney-client relationship should be deemed to be established and he should be liable if his negligence causes harm to the individual.

Comment, Attorney Malpractice, supra note 78, at 758 n.50 (citing William L. Prosser, HANDBOOK OF THE LAW OF TORTS $§ 56$ (4th ed. 1971)); accord 1 Ronald E. MALlen \& JeFFREY M. SMith, LEGAL MALPRACTICE $\$ 8.2$, at 559 (4th ed. 1996) ("If the party is not adverse, gratuitous advice can suffice for imposing a duty of care. In some jurisdictions, the measure of care is the same standard of care as if there were a formal retainer."); PROSSER AND KEETON ON THE LAW OF TORTS $§ 56$ (W. Page Keeton et al. eds., 5th ed. 1984) (noting the difference between misfeasance and nonfeasance and the importance of an affirmative act in creating a legal duty); cf. O’Neill v. Montefiore Hosp., 202 N.Y.S.2d 436, 440 (App. Div. 1960) ("The law is settled that a physician who undertakes to examine or treat a patient and then abandons him, may be held liable for malpractice."). Nevertheless, the cases in which such liability has been found are rare. See Hacker v. Hillard, 570 N.E.2d 951, 956 (Ind. Ct. App. 1991) ("The cases actually applying this rule to find attorney liability are few, and liability has been found only when the attorney undertook, gratuitously or otherwise, to complete an affirmative act for the party who later brought suit."). Moreover, these situations have traditionally been viewed as an aspect of nonclient, third-party liability, rather than implied attorney-client relationships. See Nancy J. Moore, Expanding Duties of Attorneys to "Non-Clients": Reconceptualizing the Attorney-Client Relationship in Entity Representation and Other Inherently Ambiguous Situations, 45 S.C. L. REV. 659, 660 (1994).

112. See Togstad v. Vesely, Otto, Miller \& Keefe, 291 N.W.2d 686, 693 (Minn. 1980).

113. See id.

114. See id. Although there are relatively few cases in which courts have actually imposed liability based on an implied attorney-client relationship, this may simply reflect that the issue is rarely contested in a typical legal malpractice action. Numerous courts have asserted that an attorney-client relationship can be implied if the attorney gives legal advice. See, e.g., Randolph v. Resolution Trust Corp., 995 F.2d 611, 615 (5th Cir. 1993) (holding that an attorney-client relationship may be implied by conduct); DeVaux v. American Home Assurance Co., 444 N.E.2d 355, 357 (Mass. 1983) (holding that a contract is implied when a party solicits from an attorney legal advice within the attorney's professional competence and the attorney agrees to give it); In re Perry, 494 N.W.2d 290, 294-95 (Minn. 1992) (ruling that an attorney's court appearances and drafting of documents on behalf of his ailing mother constituted legal advice and thus created an attorney-client relationship). 
To create an attorney-client relationship, however, the lawyer's advice must be specific to the facts of the putative client's case. First, as previously noted, giving specific legal advice in response to a set of particular facts is the hallmark of the practice of law, while providing general information about the law is not. ${ }^{115}$ Second, it is reasonable for a putative client to rely on advice that is specifically tailored to his particular request, and the courts are clear that it is the reasonable belief of the client that will govern. ${ }^{116}$ Defining a bright line between

115. See supra note 58.

116. See Westinghouse Elec. Corp. v. Kerr-McGee Corp., 580 F.2d 1311, 1319 (7th Cir. 1978) (noting that the privileges of the attorney-client relationship are based on the client's intention to obtain legal advice and the belief that he is consulting a lawyer for that purpose); Keoseian v. Von Kaulbach, 707 F. Supp. 150, 152 (S.D.N.Y. 1989) ("In every situation where an attorney-client relationship has been found ... the client's belief has some reasonable basis in fact that he has some interest of his own in common with others which he is seeking to advance by securing legal advice."); Alexander v. Superior Court, 685 P.2d 1309, 1314 (Ariz. 1984) (noting that a client's reasonable belief that an attorney-client relationship existed is an important factor in the court's evaluation of the relationship); Foulke v. Knuck, 784 P.2d 723, 726 (Ariz. Ct. App. 1989) (considering the client's belief that he is seeking and receiving legal advice on a specific matter); In re Lieber, 442 A.2d 153, 156 (D.C. Ct. App. 1982) (considering the client's perception of an attorney as retained legal counsel as a factor in determining whether an attorney-client relationship exists); George v. Caton, 600 P.2d 822, 827 (N.M. 1979) (finding that an attorney-client relationship existed without proof of the essential terms, because the attorneys had failed in their responsibility to be clear enough to avoid a misunderstanding of the relationship); In re Galton, 615 P.2d 317, 325 (Or. 1980) (holding that a lawyer who furnished legal advice free of charge to a corporation that called from time to time seeking advice could be considered an attorney for the corporation, because a lawyer not on retainer "[may] be considered an attorney for a client who, from time to time, calls that lawyer seeking legal advice and receives such advice as a matter of course"); Intercapital Corp. v. Intercapital Corp., 700 P.2d 1213, 1215-16 (Wash. Ct. App. 1985) (regarding a consultation and the client's view that the attorney was being retained as enough to establish an attorney-client relationship); Developments in the Law - Conflicts of Interest in the Legal Profession, 94 HARV. L. REV. 1244, 1322 (1981) [hereinafter Developments in the Law] ("The focus on the client's perspective, rather than on the sometimes misleading external indicia of the objective approach, safeguards an individual's belief and reliance."); see also Sandum v. Doherty, Rumble \& Butler, No. C7-94-801, 1994 WL 593925, at*3 (Minn. Ct. App. Nov. 1, 1994) ("Although we decline to mandate that direct contact between the plaintiff and the attorney must always occur in order for an attorney-client relationship to exist, the plaintiff's reliance on the legal advice must be reasonable under the circumstances." (emphasis added)). In contrast, if no individualized advice is given, it is unreasonable for the layperson to believe that a professional relationship has been created. See Cole v. Ruidoso Mun. Sch., 43 F.3d 1373, 1384-85 (10th Cir. 1994) (holding that an individual who contacted a law firm as principal of an organization had no reasonable basis for concluding that the attorney represented her as an individual); In re Cumberland Investment Corp., 120 B.R. 627, 629 n.3 (Bankr. D. Ky. 1990) (stating that one factor to consider when determining whether there was an attorney-client relationship is whether the individual "sought individual legal advice or asked questions relating to personal representation"). 
general information and specific legal advice, however, has proved difficult. ${ }^{117}$

There is no reason to believe that these consent-by-performance principles would not also be applicable in cyberspace. Suppose that Mrs. Togstad had posted her question about medical malpractice to the Dear Esquire website and that attorney Miller had posted the reply that he gave her orally in the office. This reply surely could meet the test of creating an attorney-client relationship. Even though one could argue that it is unreasonable for online questioners to rely on such advice, the case law discussed above suggests that the courts are willing to take a broad view of reasonableness and to treat fairly casual interactions between lawyers and laypeople as sufficient to create professional obligations. Moreover, because the factual context of the disputed exchange is necessarily critical to this determination, courts will have to look to the unique nature of cyberspace communication to decide whether a reasonable consumer of online legal services would rely on the information provided. ${ }^{118}$ In the Dear Esquire exchange we considered earlier, ${ }^{119}$ a court could well conclude that it was reasonable for the questioner to rely on an apparently specific and definitive legal opinion given in response to his request.

In short, lawyers who provide specific legal advice online may find it difficult at some future point to persuade a court or bar counsel that they did not intend to incur any professional obligations by answering questions in cyberspace. Therefore, the question of whether lawyers can give such advice and simultaneously disclaim any responsibility for its accuracy must be considered.

117. See Sandra E. Purnell, Comment, The Attorney as Mediator-Inherent Conflict of Interest?, 32 UCLA L. REV. 986, 1010 (1985) ("No bright line can be drawn between giving advice and providing impartial information.”).

118. The possibility that specific legal advice given online could create an attorney-client relationship has been addressed by a few bar opinions. See Ill. St. Bar Ass'n, Op. 96-10 (1997) ("[L]awyers participating in chat groups or other on-line services that could involve offering personalized legal advice to anyone who happens to be connected to the service should be mindful that the recipients of such advice are the lawyer's clients, with the benefits and burdens of that relationship"); Phila. Bar Ass'n Prof'l Guidance Comm., Op. 98-6 (1998) (cautioning that an attorney's responding to a question about a class action in an online discussion group could create an attorney-client relationship if the layperson reasonably believed it to be legal advice). For further discussion, see infra Part III.E.

119. See supra note 15 and accompanying text. 


\section{The Lawyer Fails to Manifest Lack of Consent, and the Lawyer Knows or Reasonably Should Know That the Person Reasonably Relies on the Lawyer to Provide the Services}

The Restatement identifies an alternative way of creating an attorney-client relationship in the face of a request for legal services, one derived from the theory of promissory estoppel. ${ }^{120}$ Two prongs must be satisfied. First, the lawyer must fail to manifest a lack of consent to the creation of a professional relationship. ${ }^{121}$ Second, the lawyer must know or reasonably should know that the person is reasonably relying on the lawyer to perform the services. ${ }^{122}$

Togstad can also be seen as an example of this method of creating an attorney-client relationship. In Togstad, attorney Miller failed to make clear to Mrs. Togstad that he did not intend to act as her attorney and to advise her about her malpractice claim. ${ }^{123}$ Moreover, because he gave her an assessment of the merits of her claim and made representations that he would take additional steps on her behalf, ${ }^{124}$ he reasonably should have known that she reasonably was relying on him to determine whether she had a case that was worth pursuing. ${ }^{125}$ Although such cases are uncommon, there are situations in which courts have found sufficient evidence to warrant consideration of whether an attorney-client relationship was created by a lawyer's failure to disclaim such a relationship in the face of reasonable reliance by the putative client. ${ }^{126}$

120. See Restatement (SECOND) OF Contracts § 90(1) (1979) (stating that if the promisee reasonably relies on a promise, the promise is binding "if injustice can be avoided only by enforcement of the promise"). Although commentators differ as to whether the resulting liability of the lawyer is the product of an actual attorney-client relationship, as the Restatement apparently assumes, or whether it is the court that imposes the obligations of an attorney-client relationship even where none has been created, the effect is the same in either scenario. For a modern critique of the concept of promissory estoppel, see Sidney DeLong, The New Requirement of Enforcement Reliance in Commercial Promissory Estoppel: Section 90 as Catch-22, 1997 WIS. L. REV. 943.

121. See Restatement (SECOND) OF Contracts § 90(1) (1979).

122. See id. (stating that "the promisor should reasonably expect to induce action" by the promisee).

123. See Togstad v. Vesely, Otto, Miller \& Keefe, 291 N.W.2d 686, 693 (Minn. 1980).

124. See id. at 690.

125. See id. at 693.

126. See, e.g., Van Brode Group, Inc. v. Bowditch \& Dewey, 633 N.E.2d 424, 428-29 (Mass. App. Ct. 1994) (stating that attorneys have a fiduciary duty toward nonclients who the attorney knows will rely on services rendered); Parker v. Carnahan, 772 S.W.2d 151, 157 (Tex. App. 1989) (holding that if an attorney is aware or should be aware that her conduct could lead a 
A similar scenario easily could arise in an online exchange, as in the Dear Esquire exchange. ${ }^{127}$ A lawyer could give specific legal advice in response to an online query without indicating that she did not wish to undertake a full-fledged representation. At the same time, the nature of the communication could give the lawyer either actual or constructive knowledge that the questioner intends to rely on the advice or is otherwise depending on the lawyer to protect his legal interests. Such a situation would meet the requirements of the Restatement, and could thereby result in liability for an unwary lawyer.

Many have assumed that the simple solution to this problem would be for lawyers to disclaim any intent to create an attorneyclient relationship. Theoretically, such disclaimers would defeat both prongs of the Restatement definition, as they would simultaneously manifest a lack of consent of the lawyer and render any reliance by the questioner unreasonable. In the alternative, a disclaimer that did not defeat the formation of an attorney-client relationship might nonetheless serve to limit liability by limiting the scope of representation. I consider each of these possibilities in turn.

1. Using Disclaimers to Avoid Attorney-Client Relationships. Not surprisingly, most attorneys include some type of disclaimer in their responses to questions or on their websites, some of which we examined above. ${ }^{128}$ Indeed, much of the legal advice-giving activity online seems to hinge on the belief that blanket use of disclaimers will protect lawyers against all risks associated with their conduct. Many commentators have advocated the use of disclaimers, without looking more closely at whether they would be legally effective against a private malpractice claim or would ward off disciplinary action. $^{129}$

reasonable person to believe that she was being represented by the attorney, a duty arises for the attorney to advise the client that she is not representing the client). See generally John F. Sutton, Jr., The Lawyer's Fiduciary Liabilities to Third Parties, 37 S. TEX. L. REV. 1033, 105658 (1996) (discussing the factual issue of whether the attorney-client relationship arises from particular conduct).

127. See supra note 15 and accompanying text.

128. See supra notes 11-20 and accompanying text.

129. See, e.g., Castellano, supra note 27, at 1 (noting the advice of several experts and experienced attorneys that lawyers employ disclaimers); Hunt, supra note 27, at 561-64 (advocating blanket use of disclaimers). It might also be argued that no disclaimer is ever necessary online because it is per se unreasonable for anyone to rely on legal advice that she obtains in cyberspace. As activity in cyberspace becomes increasingly common, it is unlikely that such an argument would prove persuasive. 
The answer to whether an attorney-client relationship may be avoided by way of disclaimer may not be as obvious as it appears at first glance. There are three possible approaches to this question: (1) an attorney may always disclaim the creation of a relationship; (2) an attorney may never disclaim the creation of a relationship; and (3) the effectiveness of disclaimers depends on the conduct of the lawyer and the reasonable expectations of the putative client.

The assertion that any disclaimer of the intent to create an attorney-client relationship would always be effective has some force, as it is consistent with the traditional understanding of the attorney-client relationship as one of contract. Case law permits lawyers expressly to avoid creating professional relationships ${ }^{130}$ and ethical rules require lawyers to make clear in ambiguous situations whether they intend to undertake a representation. ${ }^{131}$ Ordinarily, a lawyer need not enter

130. See, e.g., Green v. Montgomery County, 784 F. Supp. 841, 846 (M.D. Ala. 1992):

If, for example, the attorney has made it clear to the would-be client that there is no attorney-client relationship and if the evidence further reflects that the would-be client should have known that the relationship had not advanced to the point at which it could be deemed a representation, then there would be no attorney-client relationship despite the would-be client's subjective belief.

See also State v. Hansen, 862 P.2d 117, 121 (Wash. 1993) (en banc) (holding that when a lawyer told a potential client in an initial telephone call that he would not represent him, the content of the telephone call was not protected by attorney-client privilege, either because no attorneyclient relationship arose or because it was terminated by disclaimer prior to the incriminating statements made by the putative client); Bohn v. Cody, 832 P.2d 71, 75 (Wash. 1992) (en banc) (holding that a client's subjective belief does not govern "unless it is reasonably formed based on the attending circumstances, including the attorney's words or actions," and that the client must show that the lawyer "acted inconsistently" with disclaimers of representation). In the context of real estate transactions, one court has noted that "'a simple clause in the agreement stating that it was prepared by the attorney for the opposite party acting solely on behalf of that party's interest, and advising the other parties to seek independent legal counsel to protect their own interests" could avoid later claims of justifiable reliance. Hacker v. Holland, 570 N.E.2d 951, 956 n.6 (Ind. Ct. App. 1991) (quoting Fox v. Pollack, 226 Cal. Rptr. 532, 534 n.2 (Cal. Dist. Ct. App. 1986)). Disclaimers have also been advocated to avoid third-party liability for opinion letters. See Mark Twain Kansas City Bank v. Jackson, Brouilette, Pohl \& Kirley, P.C., 912 S.W.2d 536, 540 (Mo. Ct. App. 1995). See generally John H. Bauman, A Sense of Duty: Regulation of Lawyer Responsibility to Third Parties by the Tort System, 37 S. TEX. L. REV. 995, 1013-14 (1996) (discussing courts' treatment of lawyer disclaimers limiting the application of communication).

131. See Model Rules of Professional Conduct Rule 4.3 (1998):

In dealing on behalf of a client with a person who is not represented by counsel, a lawyer shall not state or imply that the lawyer is disinterested. When the lawyer knows or reasonably should know that the unrepresented person misunderstands the lawyer's role in the matter, the lawyer shall make reasonable efforts to correct the misunderstanding. 
into a representation to which she does not consent, and any expression of non-consent should suffice to defeat a subsequent claim that a relationship was created, particularly since the burden of proof of the existence of the relationship ordinarily rests with the putative client. ${ }^{132}$ Under this view, the fact that legal advice is given in tandem with a disclaimer is largely irrelevant. In the employment context, for example, courts have been willing to give legal effect to disclaimers that appear in employee handbooks, even when the conduct of the employer is inconsistent with the disclaimer. ${ }^{133}$ Moreover, as I discuss in Part III, various bar opinions have either recommended or required that lawyers disclaim the creation of attorney-client relationships when they give legal advice in nontraditional contexts. ${ }^{134}$

See also id. Rule 1.13(d) ("In dealing with an organization's directors, officers, employees, members, shareholders or other constituents, a lawyer shall explain the identity of the client when it is apparent that the organization's interests are adverse to those of the constituents with whom the lawyer is dealing."). See generally Geoffrey C. Hazard, Jr., The Privity Requirement Reconsidered, 37 S. TEX. L. REV. 967, 988-89 (1996) (noting that under strict privity there would be no liability for negligent advice to a corporate constituent, but there could be an issue of fact as to whether the constituent reasonably believed himself to be represented by the corporate lawyer).

132. See Veit v. Anderson, 428 N.W.2d 429, 431 (Minn. Ct. App. 1988) (holding that the existence of an attorney-client relationship was a question of fact to be proven by the plaintiff at trial).

133. Early employee handbook cases encouraged employers to limit their liability by using disclaimers. See Woolley v. Hoffmann-LaRoche, 491 A.2d 1257, 1265 (N.J. 1985) (holding that handbook provisions are binding on an employer "unless the language contained in the manual were such that no one could reasonably have thought it was intended to create legally binding obligations"). See generally Michael A. Chagares, Utilization of the Disclaimer as an Effective Means to Define the Employment Relationship, 17 HofsTRA L. REV. 365 (1989) (discussing effective ways to use disclaimers to define the terms of an employment relationship). Courts have tended to uphold such disclaimers even when the employees are legally unsophisticated. See DeLong, supra note 120, at 1010-11 (asserting that although employees are rarely experienced business persons represented by attorneys, disclaimers usually prevent a later assertion of promissory estoppel). The voluminous case law is collected in George L. Blum, Annotation, Effectiveness of Employer's Disclaimer of Representations in Personnel Manual or Employee Handbook Altering At-Will Employment Relationships, 17 A.L.R.5th 1 (1994). In other situations, ambiguity or conduct inconsistent with the terms of the disclaimer has rendered the disclaimer ineffective. See, e.g., Mcllravy v. Kerr-McGee Corp., 74 F.3d 1017, 1022 (10th Cir. 1996) (stating that an effective disclaimer must be "conspicuous and clear"); Mecier v. Branon, 930 F. Supp. 165, 169 (D. Vt. 1996) (ruling that disclaimers must be evaluated in the context of other circumstances bearing on the agreement); Wlasiuk v. Whirlpool Corp., 914 P.2d 102, 111 (Wash. Ct. App. 1996) (holding that a jury could find that an employee reasonably relied upon promises relating to treatment in specific situations).

134. See, e.g., Fla. St. Bar Ass'n Comm. on Prof'l Ethics, Op. 70-30 (1970) (limiting an attorney's question-answer column in a newspaper to general questions answered in a "lecture tone" and prohibiting specific answers to individual legal questions); Iowa Sup. Ct. Bd. of Prof'l Ethics \& Conduct, Op. 90-46 (1991) (requiring disclaimers in radio announcements providing background information on the justice system); Md. St. Bar Ass'n Comm. on Ethics, Op. 85-13 
A recent example of an apparently effective disclaimer is discussed in People v. Gionis, ${ }^{135}$ in which a former client made incriminating statements to a lawyer, who gave him gratuitous personal and legal advice. The court rejected a later attempt to suppress the statements as subject to the attorney-client privilege, on the grounds that the parties no longer had a professional relationship, that the conversation did not touch on legal matters, and that the lawyer had expressly refused to represent the former client. ${ }^{136}$ The concurrence noted the difficulty for a layperson when the lawyer's conduct in giving advice is inconsistent with the lawyer's disclaimer: "In view of the frequency with which some persons seek to obtain informally and gratuitously valuable legal advice, and the lamentable frequency with which attorneys submit to such an imposition ... it is often difficult to determine whether the consultation is a professional one, within the

(1984) (authorizing an attorney to give general advice on a five-minute weekly radio program if the audience is cautioned to seek legal advice as warranted and the attorney's name is not disclosed); N.H. Bar Ass'n Ethics Comm., Op. 1994-95/3 (1995) (requiring a radio program in which attorneys provide general answers to factual situations provided by callers to include an "extensive disclaimer, broadcast more frequently than at the beginning and end of the program”); N.Y. St. Bar Ass'n Comm. on Prof'l Ethics, Op. 664 (1994) (requiring a lawyer giving advice over the phone to inform the caller: (1) that some issues may not be appropriate for this medium; (2) whether the advice is general or specifically tailored to the caller's predicament; (3) of arrangements in case further legal work is required; and (4) of limits on the representation); Or. St. Bar Ass'n Legal Ethics Comm., Op. 1994-137 n.2 (1994) (suggesting that an online legal information service include a disclaimer to avoid consumer expectation of an attorneyclient relationship); Sup. Ct. of Tex. Prof'l Ethics Comm., Op. 425 (1985) (advising that lawyers educating the public should caution an audience not to attempt to solve problems on the basis of information provided). Other opinions providing similar admonitions are Ala. St. Bar, Op. 87-141 (1987); id. Op. 86-27 (1986); Conn. Bar Ass'n Comm. on Prof'l Ethics, Op. 89-19 (1989); id. Op. 89-4 (1989); Iowa Sup. Ct. Bd. of Prof'l Ethics \& Conduct, Op. 91-50 (1992); id. Op. 8941 (1990); Kan. Bar Ass'n Comm. on Ethics/Advisory Servs., Op. 92-06 (1992); Md. St. Bar Ass'n Comm. on Ethics, Op. $82-60$ (1982); N.H. Bar Ass'n Ethics Comm., Op. 1992-93/11 (1993); N.J. Sup. Ct. Advisory Comm. on Prof'l Ethics, Op. 480 (1981); N.Y. St. Bar Ass'n Comm. on Prof'l Ethics, Op. 625 (1992); Ohio Sup. Ct. Bd. of Comm'rs on Grievances \& Discipline, Op. 94-13 (1994); Pa. Bar Ass'n Comm. on Legal Ethics \& Prof'l Responsibility, Op. 87-1 (1987); S.C. Bar Ethics Advisory Comm., Op. 86-4 (undated); Sup. Ct. of Tex. Prof'l Ethics Comm., Op. 394 (1979); Utah St. Bar Ethics Advisory Opinion Comm., Op. 96-12 (1997); Va. St. Bar Standing Comm. on Legal Ethics, Op. 1642 (1995); id. Op. 1577 (1994); id. Op. 410 (1983); Va. St. Bar Standing Comm. on Unauthorized Prac. of L., Op. 185 (1995).

135. 40 Cal. Rptr. 2d 456 (Cal. 1995). Gionis is discussed in Dennis Michael Torrey, Note, People v. Gionis: Beware of Gratuitous Advice, Attorneys May Testify Against a Business Acquaintance or Friend, 18 THOMAS JEFFERSON L. REV. 97 (1996).

136. See Gionis, 40 Cal Rptr. 2d at 465 . The result in Gionis seems inconsistent with traditional attorney-client privilege, in that the privilege has often been held to attach to preliminary conversations between lawyers and potential clients, even if those communications do not result in a professional relationship. See Torrey, supra note 135, at 108-09. 
privilege." ${ }^{137}$ Nonetheless, it is well settled that the mere subjective expectation of a putative client will not suffice to create an attorneyclient relationship where none was intended by the attorney. ${ }^{138}$

The courts are unlikely to treat disclaimers as a magic shield for online lawyers, however. Indeed, if disclaimers could be so easily utilized, a lawyer could avoid the prospect of malpractice liability, or even the reach of most ethics rules, simply by expressly disclaiming the intent to create an attorney-client relationship with anyone. ${ }^{139}$ Lawyers could announce at the beginning of every office visit that they do not wish to enter into a professional relationship and that the information they are giving is not really legal advice, a practice that has been condemned by at least one bar opinion. ${ }^{140}$ To take an ex-

137. Gionis, 40 Cal. Rptr. 2d at 473 (Kennard, J., concurring and dissenting) (quoting 8 WIGMORE ON EVIDENCE $§ 2303$, at 584 (McNaughton ed. 1961)).

138. See Developments in the Law, supra note 116, at 1323 (citing Levin v. Ripple Twist Mills, Inc., 416 F. Supp. 876, 883-84 (E.D. Pa. 1976)):

If, for example, the attorney has made it clear to the party that there would be no representation and if the court is convinced that the party should have known that the relationship had not advanced to the point at which it could be deemed a 'representation,' a court may find that there was no attorney-client relationship despite the party's subjective belief.

See also In re Weidner, 801 P.2d 828, 837 (Or. 1990) (per curiam) ("The evidence must show that the lawyer understood or should have understood that the relationship existed, or acted as though the lawyer was providing professional assistance or advice on behalf of the putative client."). Among the factors to be considered is the putative client's subjective intention or expectation, but there are numerous others:

evidence of objective facts on which a reasonable person would rely as supporting existence of that intent, evidence placing a lawyer on notice that the putative client had that intent, evidence that the lawyer shared the client's subjective intention to form a relationship, or evidence that the lawyer acted in a way that would induce a reasonable person in the client's position to rely on the lawyer's professional advice.

Id. at 837 .

139. Although one might argue that a lawyer who pursued this approach would soon have no clients, we should recall that many people of moderate means might feel that they have no recourse but to accept even such a limited promise of help from a lawyer.

140. See N.C. Bar Ass'n Ethics Comm., Op. RPC 244 (1996). The opinion stated that it was impermissible for a lawyer to begin every free initial consultation by having the prospective client sign an intake sheet that read:

It is acknowledged that my appointment is for a free office consultation. No legal advice will be given. I will be provided only general information concerning North Carolina laws. Upon a request, a fee will be quoted for legal representation. I understand that no attorney-client privilege will exist unless and until I pay this firm to represent me and that this free consultation will not preclude my spouse from employing Attorney X or any other attorney with XYZ Law Firm. 
treme example, a lawyer who accepted a retainer and filed a complaint in court on behalf of a person could hardly avoid subsequent malpractice liability by asserting that she had expressly disclaimed the intent to create an attorney-client relationship, even if she had such a disclaimer in writing. ${ }^{141}$ The lawyer's actions would speak louder than the lawyer's words. At some point, the conduct of the lawyer would be so inconsistent with the disclaimer of a professional relationship that the disclaimer would be treated as ineffective.

One could also take the opposite position and claim that an attorney may never avoid the creation of an attorney-client relationship by way of disclaimer. The rationale for such a rule would be that it is the conduct of the lawyer and the expectations of the client that should govern, rather than the boilerplate terms of some written warning. If the lawyer purports to provide legal services to an individual, that action triggers professional obligations regardless of whether the lawyer has sought to avoid them. One might also argue that the inequality of knowledge and bargaining power between lawyers and putative clients suggests that disclaimers should be treated as contracts of adhesion. ${ }^{142}$ Togstad again is the paradigm. There the lawyer expressly told the would-be client that he did not wish to represent her, but at the same time he gave her legal advice on which she justifiably relied. ${ }^{143}$ In other settings, the courts have suggested that conduct inconsistent with the lawyer's overt denial of an intent to create an attorney-client relationship may override the disclaimer, ${ }^{144}$

141. This scenario arguably would implicate Model Rule 1.8(h), which precludes agreements that prospectively limit malpractice liability to a client unless permitted by law and unless the client is independently represented by counsel. See MODEL RULES OF PROFESSIONAL CONDUCT Rule 1.8(h) (1998). Model Rule 1.8(h) presupposes the existence of an attorneyclient relationship and thus is analytically distinct from the hypothetical under discussion, in which the lawyer attempts to avoid at the outset the creation of a relationship that might bring with it potential malpractice liability. See id.

142. See generally SAMUEL WiLliston, WiLliston ON CONTRACTS $§ 18$ (Richard A. Lord ed., 4th ed. 1990) (outlining the law pertaining to unconscionable agreements).

143. See Togstad v. Veseley, 291 N.W.2d 686, 693 (Minn. 1980).

144. For example, in Hacker v. Holland, 570 N.E.2d 951, 955-56 (Ind. Ct. App. 1991), the court remanded on the issue of whether the seller in a real estate transaction had justifiably relied on representations by the purchaser's attorney: "An attorney has in effect consented to the establishment of an attorney-client relationship if there is "proof of detrimental reliance, when the person seeking legal services reasonably relies on the attorney to provide them and the attorney, aware of such reliance, does nothing to negate it.'" Id. at 956 (quoting Kurtenbach v. Tekippe, 260 N.W.2d 53, 56 (Iowa 1977)). In contrast, a concurring judge argued that no attorney-client relationship was created by promissory estoppel because "many duties, responsibilities and consequences attach to a true attorney-client relationship which do not come into 
especially since these principles will be construed against the lawyer. ${ }^{145}$ Further, a variety of bar opinions have taken the position that an attorney-client relationship, once created, cannot be disclaimed. ${ }^{146}$

play with regard to the status of the parties as defined by a promissory estoppel situation." Id. at 959 (Sullivan, J., concurring); see also Bohn v. Cody, 832 P.2d 71, 77 (Wash. 1992) (holding that even though a lawyer specifically disclaimed any relationship with third parties, the lawyer's giving of legal advice raised a material fact as to whether the lawyer is liable for negligence: "Under the extreme facts of this case, we hold simply that an attorney should advise the unrepresented party to seek independent counsel before the attorney discusses the transaction with that party."); $c f$. Williams v. Fortson, Bentley \& Griffin, 441 S.E.2d 686, 687 (Ga. Ct. App. 1994) (observing that a lawyer's conduct at a real estate closing was inconsistent with a signed disclaimer of the attorney-client relationship but still finding no relationship). In a different context, the Iowa Supreme Court held that an attorney who surreptitiously tape-recorded an individual for law enforcement purposes while expressly advising him to obtain individual counsel and disclaiming any attorney-client relationship was nevertheless subject to bar discipline for deceit: "That the trickery occurred outside the strict bounds of an attorney-client relationship is, we think, of only passing significance." Committee on Prof'l Ethics and Conduct of the Iowa State Bar Ass'n v. Mollman, 488 N.W.2d 168, 171 (Iowa 1992).

145. See Green v. Montgomery County, 784 F. Supp. 841, 846 (M.D. Ala. 1992) (“[T]he test for determining the existence of this fiduciary relationship is a subjective one and hinges upon the client's belief that he is consulting a lawyer in that capacity and his manifested intention is to seek professional legal advice." (citations and internal quotations omitted)); Bennett Silvershein Assocs. v. Furman, 776 F. Supp. 800, 802 (S.D.N.Y. 1991) ("Thus, although doubts should be resolved in favor of disqualification, the party seeking disqualification must carry a heavy burden and must meet a high standard of proof before a lawyer is disqualified." (citations and internal quotation marks omitted)); In re Johore Inv. Co., 49 B.R. 710, 713 (Bankr. D. Haw. 1985) ("If there is a doubt as to the existence of an asserted conflict of interest, the conflict should be resolved in favor of disqualification."); Reardon v. Marlayne, 416 A.2d 852, 858 (N.J. 1980) ("If there be any doubt as to the propriety of an attorney's representation of a client, such doubt must be resolved in favor of disqualification."); Seeley v. Seeley, 514 N.Y.S.2d 110, 112 (App. Div. 1987) (noting the "settled principle that doubts as to the existence of a conflict of interest must be resolved in favor of disqualification so as to avoid even the appearance of impropriety"); Bruce L. Silverstein, Attorney Disqualification for a Conflict of Interest in Federal Civil Litigation: A Confusing Body of Law in Need of Organization, 30 VILL. L. REv. 463, 467 (1985) (discussing the presumption of "disclosed confidences" and the presumption of "shared confidences" as two principles often applied by courts in determining whether to disqualify a challenged attorney for a conflict of interest); Purnell, supra note 117, at 993-95 (describing how a policy of protecting clients has led courts to focus on whether a plaintiff had a reasonable belief that an attorney-client relationship had been created); see also Perschbacher \& Perschbacher, supra note 80, at 704 ("It is the lawyer who is in the best position to set the tone for an initial meeting ... . The lawyer knows the ethical rules; the lawyer has the legal background enabling him to anticipate the possible scenarios.").

146. See, e.g., Kan. Bar Ass'n Comm. on Ethics/Advisory Servs., Op. 93-8 (1993) (“A lawyer operating a ' 900 ' pay-for-information telephone number by which callers are given legal information ... enters into a lawyer-client relationship with the caller and may not avoid it by disclaimer."); N.J. Sup. Ct. Comm. on Unauthorized Prac., Op. 17 (1994) (opining that once an attorney decides to render legal advice to a client or perspective client through a 900 number, an attorney ought not to be able to avoid malpractice liability by claiming that no attorneyclient relationship exists); Utah St. Bar Ethics Advisory Opinion Comm., Op. 96-12 (1997) ("[I]f legal advice is sought from an attorney, if the advice sought is pertinent to the attorney's 
The truth, as usual, probably lies somewhere between these two extremes. Whether a lawyer will be able to rely on a disclaimer will hinge on the nature of the request for advice, the conduct of the lawyer in response to the request, and the factual circumstances surrounding the disclaimer. Having taken the safe middle course, however, I hasten to add that I expect that neither courts nor bar disciplinary authorities are likely to be sympathetic to cyberspace attorneys who rely on disclaimers as all-purpose shields. In my view, if the legal advice given is specifically tailored to the factual circumstances presented, that conduct will suffice to create an attorney-client relationship, regardless of what boilerplate disclaimers the lawyer attaches to the advice. An online disclaimer is more placebo than panacea.

Several factors lead me to this conclusion. The first factor is the nature of the lawyer's conduct. Giving legal advice in response to a particularized inquiry is at the heart of the practice of law. ${ }^{147}$ A questioner is far more likely to rely on advice that is carefully tailored to his unique factual situation, and so the more detailed the response, the more reasonable it would be for a layperson to rely on the advice given. ${ }^{148}$ Second, the nature of disclaimers in cyberspace may create difficulties in enforcing them, as they may easily be ignored or avoided with the inadvertent click of a mouse. Even if lawyers use devices that require assent to a disclaimer before the questioner can proceed, such conduct still presents difficulties in light of the courts' traditional protectiveness of laypeople in transactions with attorneys. Courts ordinarily will examine the facts surrounding the alleged creation of a professional relationship from the reasonable perspective of the putative client. ${ }^{149}$ Even in the face of elaborate written disclaimers, courts may well find it reasonable for laypeople to treat such disclaimers as nothing more than "legalese," particularly if the conduct of the attorney is inconsistent with the disclaimer. ${ }^{150}$ In addition, unhappy online clients are likely to assert traditional contract challenges, arguing that these disclaimers are unconscionable contracts of

profession, and if the attorney gives the advice for which fees will be charged, an attorney/client relationship is created that cannot be disclaimed by the attorney.").

147. See supra note 58 .

148. See Steimer, supra note 27, at 347-48 (stating that consideration of online questioners as clients would depend on a court's willingness to infer a contractual relationship, which "depends in part on the extensiveness of the advice sought and the fact-intensiveness of the answer given by the attorney").

149. See supra note 145 and accompanying text.

150. See supra notes 143-144 and accompanying text. 
adhesion, that they should be read narrowly because they purport to exculpate lawyers from tort liability, or that they are inconsistent with the administration of justice. ${ }^{151}$ Indeed, even if disclaimers in general were ultimately held to be permissible by the courts, the specifics of many online disclaimers might well be insufficient to guard against liability. ${ }^{152}$

Perhaps the most persuasive consideration is the legal profession's historical opposition to legal advice-giving in nontraditional contexts, as well as its general unwillingness to endorse the blanket use of disclaimers to guard against the risks arising from lawyers' giving specific legal advice to strangers. I address this history in Parts II and III.

2. Using Disclaimers to Limit the Scope of Representation. Even if a disclaimer does not prevent formation of an attorney-client relationship, it may still serve a purpose. Suppose that an online client like Mrs. Togstad sues her cyberlawyer for negligent advice, and further assume that a court would find that the online disclaimer did not suffice to defeat the formation of an attorney-client relationship. The online lawyer might argue in the alternative that the disclaimer serves as a limitation of the objectives of the representation, as described in section 30 of the Restatement (Third) of the Law Governing Lawyers, entitled "Limitation of Client or Lawyer Duties": "Subject to other requirements stated in this Restatement, a client and lawyer may agree to limit a duty that a lawyer would otherwise owe to the client if: (a) the client is adequately informed and consents; and (b) the terms of the limitation are reasonable in the circumstances." 153 Similarly, Model Rule 1.2(c) provides: "A lawyer may limit the objectives of the representation if

151. See generally WiLLISTON, supra note 142, § 18 (discussing unconscionable agreements); id. § 19:21 (discussing strict construction of exculpatory contracts); id. § 12 (discussing the voiding of contracts as against public policy); WOLFRAM, supra note $98, \S 9.1$ (discussing regulation of lawyer-client contracts).

152. Among the many potential challenges to the substance of the disclaimers is that they are inherently false and misleading under Model Rule 7.1, that they constitute prospective waivers of malpractice liability without the necessary safeguards required by Model Rule $1.8(\mathrm{~h})$, and that they impermissibly limit the scope and objectives of the representation by eradicating the duty of competence, violating Model Rules 1.2 and 1.3. See ModEL RULES OF PROFESSIONAL CONDUCT Rules 1.2, 1.3, 1.8, 7.1 (1998).

153. RestatemENT (Proposed Final Draft No. 1), supra note 60, § 30(1). 
the client consents after consultation." ${ }^{154}$ The term "consultation" in the Model Rules means "communication of information reasonably sufficient to permit the client to appreciate the significance of the matter in question." 155

The Restatement provides as an illustration of limited representation a situation in which a legal clinic provides thirty-minute reviews of tax returns for a small fee. ${ }^{156}$ The clinic explains at the outset that "the review may fail to find important tax matters" and secures in advance the client's waiver of the right to a complete evaluation without paying additional fees. ${ }^{157}$ Such a provision would be permissible, according to the Restatement, because "[t]he client's consent is free and adequately informed, and clients gain the benefit of an inexpensive but expert tax review of a matter that otherwise might well receive no expert review at all." ${ }^{\text {5158 }}$ Similarly, a disclaimer that limited the online lawyer's obligations to providing a competent legal response, without further requiring the lawyer to take steps to protect the client's interest, arguably could be consistent with these provisions, if the circumstances of the exchange reflected informed consent.

The nature of these online exchanges, however, makes it less likely that the notion of limited representation, at least as it is currently understood, would suffice to protect online lawyers against subsequent litigation. First, there are core attributes of the attorneyclient relationship, such as basic competency, that cannot be bargained away. ${ }^{159}$ The comment to Model Rule 1.2 expressly states: "An agreement concerning the scope of representation must accord with the Rules of Professional Conduct and other law. Thus, the client may not be asked to agree to representation so limited in scope as to violate Rule 1.1 ..." Second, there are difficulties inherent in crafting a disclaimer that will adequately disclose all duties that are owed and then disclaimed. Certainly the typical online disclaimer

154. Model Rules of Professional Conduct Rule 1.2(c) (1998).

155. Id. Terminology.

156. See Restatement (Proposed Final Draft No. 1), supra note 60, § 30 illus. 2.

157. Id.

158. Id.

159. See HAZARD ET AL., supra note 54, at 487 ("The Rule and Comment [to 1.2] thus preclude an agreement limiting the scope of representation to a lawyer's off-the-cuff opinion based on no research or investigation, such as the advice provided by attorney Miller in Togstad.").

160. Model Rules of Professional CONDUCt Rule 1.2 cmt. (1998). 
posted today would not meet even the most liberal definition of "informed consent" contemplated by the Restatement. ${ }^{161}$ Third, and perhaps most important, the courts may be less sympathetic to attempts to avoid malpractice liability than the drafters of the Restatement section. ${ }^{162}$ In Nichols $v$. Keller, ${ }^{163}$ for example, a California court held that a lawyer may be required to volunteer advice necessary to further the client's objectives involving matters beyond the scope of the relationship if the failure to consider such advice could result in a foreseeable adverse consequence to the client. ${ }^{164}$ The policy ramifications of permitting sharp limitations on the nature of attorney-client relationships have yet to be explored, but even the Restatement notes the risk that "[i]n the long run ... a restriction could become a standard practice that constricts the rights of clients without compensating benefits." $" 165$

I shall return to the concept of "limited representation" at the end of this Article, where I consider whether it should be used as a possible solution to the dilemma currently posed by online advicegiving. For the moment, however, it is enough to say that the principle has a number of shortcomings that make it less than a blanket remedy for lawyers in cyberspace. Let us now turn to another possible issue in this context-the question of obligations to nonclients, either as prospective clients or as third parties.

161. The comment to section 30 of the Restatement notes that an effective limitation on a lawyer's duty to a client must meet the following five requirements: (1) it must inform the client of the problems a limitation might entail; (2) it must be construed from the perspective of the reasonable client; (3) the fee charged by the lawyer must remain reasonable in view of the limited representation; (4) any change made an unreasonably long time after the representation begins must meet the more stringent tests of $\S 29 \mathrm{~A}(1)$ for post-inception agreements or modifications; and (5) the terms of the limitation must in all events be reasonable in the circumstances. See ReSTATEMENT (Proposed Final Draft No. 1), supra note $60, \S 30 \mathrm{cmt}$. c. The comment further notes: "For . . . clients [other than those sophisticated in such waivers], the requirement [of reasonableness] is met if, in addition to informed consent, the benefits supposedly obtained by the waiver . . . could reasonably be considered to outweigh the potential risk posed by the limitation." Id. $\S 30 \mathrm{cmt}$. c.

162. Indeed, the comment to section 30 identifies the protectionist concern that has often motivated the courts: "Clients unsophisticated in such limitations may well have difficulty understanding important implications of limiting a lawyer's duty. A lawyer who will benefit from the limitation cannot always be trusted to explain its costs and benefits fairly." RESTATEMENT (Proposed Final Draft No. 1), supra note 60, $30 \mathrm{cmt}$. b.

163. 19 Cal. Rptr. 2d 601 (Cal. Ct. App. 1993).

164. See id. at 608 .

165. Restatement (Proposed Final Draft No. 1), supra note $60, \S 30 \mathrm{cmt}$. b. 


\section{Alternative Theories of Liability}

1. Duties to Prospective Clients. I believe that the attorneyclient model is the most appropriate one to use in online advicegiving. However, even if that model were not applicable, the lawyer might still owe a variety of obligations to the questioner. Duties to prospective clients have been identified in a variety of contexts. Section 27 of the Restatement (Third) of the Law Governing Lawyers states: "When a person discusses with a lawyer the possibility of their forming a client-lawyer relationship for a matter or matters, and no such relationship arises, the lawyer must . . . use reasonable care to the extent the lawyer gives the person legal advice or provides other legal services for the person." 166 That section suggests that a lawyer could still be liable for negligent advice given to the prospective client, even if the circumstances do not give rise to an attorney-client relationship. The Committee on Professional Responsibility of the American Bar Association ("ABA") has also cautioned about obligations of confidentiality in this context. ${ }^{167}$ In addition, the online exchange could generate potential conflicts of interest for the lawyer, even if the exchange did not ripen into an attorney-client relationship.

2. Obligations to Nonclient Third Parties. One last potential source of liability should be considered-duties to third parties. Section 26 of the Restatement (Third) of the Law Governing Lawyers specifically contemplates that in certain circumstances lawyers may owe a variety of duties to nonclients, including duties of maintaining confidentiality, ${ }^{168}$ avoiding conflicts of interest, ${ }^{169}$ and providing competent advice. ${ }^{170}$ The comment to section 26 notes that obligations to nonclients can arise even when the lawyer has refused to accept representation. ${ }^{171}$

The issue of third-party liability has received much attention in recent years, and the arguments about the scope of this liability will

\footnotetext{
166. Id. § 27.

167. See ABA Comm. on Ethics and Professional Responsibility, Formal Op. 90-358 (1990).

168. See Restatement (Proposed Final Draft No. 1), supra note 60, $\S 27,112$.

169. See id. § 213 .

170. See id. $\$ 112$.

171. See id. $\$ 26 \mathrm{cmt}$. e, illus. 2.
} 
not be rehearsed here. ${ }^{172}$ At best, third-party liability might be the appropriate prism through which to analyze a malpractice suit brought by someone who had read a posting by a lawyer in response to someone else's query and had chosen to rely upon it. But in the situation we are considering here, where there is a direct interaction between the lawyer and the person seeking legal advice, the body of law governing third-party liability adds little to the analysis, ${ }^{173}$ other than to suggest the general fluidity of the concept of attorney-client relationships and the emerging trend in the courts to expand attorney liability. ${ }^{174}$

\section{II. "SWING-Time JUSTICE": REGULATING RADIO COURTS IN THE 1930S}

The foregoing review of various bodies of substantive law indicates the strong possibility that a lawyer who gives legal advice in response to a lay request may create, however inadvertently, an attorney-client relationship if the circumstances create a reasonable expectation in the requester. Alternatively, the lawyer may incur obligations under a variety of other theories. Nevertheless, the case law is neither extensive nor definitive. In order to flesh out the picture more fully, we must also consider the approach of the bar to the giving of legal advice in nontraditional settings. Examining the historical record will show that giving legal advice has been viewed as a hallmark of the attorney-client relationship and that the bar has been distinctly hostile to lawyers' answering lay questions about specific legal issues, regardless of the medium in which these responses occur.

172. For a good overview, see generally Symposium, The Lawyer's Duties and Liabilities to Third Parties, 37 So. TeX. L. REV. 927 (1996).

173. Two student notes addressing the issue of online legal advice have focused in part on third-party liability. See Hunt, supra note 27, at 553; Steimer, supra note 27, at 332. Steimer's note further suggests that liability for negligent legal advice online could stem from section 552 of the Restatement (Second) of Torts, which provides that "[o]ne who, in the course of his business, profession, or employment . . . supplies false information for the guidance of others in their business transactions, is subject to liability for pecuniary loss caused to them by their justifiable reliance upon the information, if he fails to exercise reasonable care ...." Without entering into an extensive critique of these approaches, I simply observe that they do not adequately address the threshold issue of whether an attorney-client relationship is created by these exchanges, which would make these more tenuous arguments about third-party liability unnecessary.

174. For an excellent overview, see Moore, supra note 111, at 659. 
Since the 1930s, the organized bar has attempted to regulate the giving of legal advice in a variety of different contexts: radio talk shows, newspaper advice columns, seminars, and 900-number telephone lines. ${ }^{175}$ As this part and the next will show, the bar has attempted to distinguish between the transmission of general legal knowledge, which it has viewed as permissible, and the presentation of specific legal advice tailored to an individual's particular problem, which it generally has tried to prohibit.

For a number of reasons, I begin this historical survey with the story of the Good Will Court. Just as computer technology has created new concerns about advice-giving by lawyers, so the emergence of radio as a means of mass communication in the 1930s generated a new vehicle for dispensing legal advice-the "radio court," in which lawyers and judges would hear the legal problems of ordinary people and attempt to solve them. Moreover, radio courts emerged during a time of widespread economic hardship, and many perceived that the legal needs of ordinary citizens were not being met. But the bar has never been particularly sympathetic to novel ways of providing basic legal advice. Although many laypeople viewed radio courts as a valuable educational service, the organized bar of the 1930s was less sanguine about the prospect of "swing-time justice." the program's debut, the controversy generated by the Good Will Court produced a flurry of bar opinions, revisions of ethical rules, and finally a court challenge, bringing this innovation to an ignominious conclusion that even the regular use of disclaimers at the beginning and end of each program could not avoid. The saga of the Good Will Court, long lost in obscurity, stands as a warning for lawyers seeking to make innovative use of new communications media because it reflects the pattern of opposition to such nontraditional methods of

175. Although past regulatory efforts by the bar can be instructive, it is important to keep in mind that some of the opposition to the giving of legal advice in nontraditional settings stemmed from the traditional ban on lawyer advertising that remained at the core of disciplinary activities until the Supreme Court's 1977 decision in Bates v. State Bar, 433 U.S. 350 (1977). See WOLFRAM, supra note $98, \S 14.2 .2$, at 777 n.26 ("The commonly accepted estimate is that half of the ABA's ethics opinions through the late 1960's dealt with advertising and related issues."); infra notes 257-258 and accompanying text (discussing Bates). Nevertheless, the fact that many bar opinions have continued to criticize such activities as they have arisen in such recent contexts as 900 telephone numbers suggests that past opposition to giving legal advice this way cannot simply be dismissed as outdated objections to lawyer self-promotion.

176. In re Blake, 17 N.Y.S.2d 496, 497 (Sup. Ct. 1939) (sharply criticizing the phenomenon of radio courts). 
dispensing legal advice that the organized bar has manifested for the last sixty years.

Although the 1930s proved to be a difficult time for lawyers economically, as for the rest of the country, ${ }^{177}$ the ABA emerged as a powerful professional organization during this same period. ${ }^{178}$ During the Depression, the organized bar became increasingly concerned with stamping out the unauthorized practice of law, ${ }^{179}$ a focus linked in no small way to the economic difficulties lawyers were experiencing. ${ }^{180}$ At the same time, the new medium of radio appeared to pose a threat to the legal profession because it offered a new method of furnishing legal information to a mass audience.

Radio's emergence as a mass medium began in earnest in the late 1920 s with the evolution of network broadcasting. ${ }^{181}$ As early as

177. See Jerold S. Auerbach, Unequal Justice 158-59 (1976) (stating that in 1933 nearly half of Manhattan lawyers had annual salaries below subsistence level).

178. In 1910, the ABA had 3690 members, about 3\% of all lawyers in the United States. By 1930, the ABA had about 27,000 members, comprising about $18 \%$ of all lawyers in the country. See James Willard Hurst, The Growth of American Law: The Lawmakers 289 (1950).

179. The ABA established its Unauthorized Practice of Law Committee in 1930. See WOLFRAM, supra note $98, \S 15.1 .1$, at 825 . A contemporaneous article in the ABA Journal explains: "The extent to which such a practice had recently grown was such as to cause the Committee to believe that a special committee was needed to give it attention." Committee on Unauthorized Practice Created, 16 A.B.A. J. 687, 687 (1930). The ABA soon sponsored publication of a handbook on unauthorized practice. See FrEDERICK C. HicKS \& ElLIOTT R. KATZ, UNAUTHORIZED PRACTICE OF LAW: A HANDBOOK FOR LAWYERS AND LAYMEN (1934). During the 20-year period between 1920 and 1940, the number and reach of state regulations also expanded dramatically:

[T] he state statute books grew to include an impressive list of bans on the unlicensed activity of real estate brokers, tax adjusters, collection agents, claims adjusters, notaries, conveyancers, probate attorneys, law students, law clerks, and legal aid associations, as well as of banks, trust companies, title companies, collection agencies, mercantile associations, insurance companies, and incorporated legal aid societies.

HURST, supra note 178, at 320-21; see also Deborah L. Rhode, Policing the Professional Monopoly: A Constitutional and Empirical Analysis of Unauthorized Practice Prohibitions, 34 STAN. L. REV. 1, 8 (1981) (noting that by 1938 over 400 state and local bar associations had established committees similar to the ABA Committee on the Unauthorized Practice of Law). For a general overview of the regulation of unauthorized practice of law, see RESTATEMENT (Third) OF LAW Governing LAWYers, $\S 4 \mathrm{cmt}$. b (Proposed Final Draft No. 2, 1998) [hereinafter RESTATEMENT (Proposed Final Draft No. 2)]

180. See HuRST, supra note 178, at 323 (suggesting that the movement was "born more of an emotional desire to do something in the face of social catastrophe, than out of any deeply reasoned analysis").

181. For good overviews of the history of radio broadcasting, see generally 1 ERIK BARNOUW, A TOWER IN BABEL: A History OF BROADCASTING IN THE UNITED STATES TO 1933 (1966); 2 ERIK BARNOUW, THE GoldEN WeB: A History of BroAdCASTING IN THE 
1933, the ABA recognized the educational value of the new medium, sponsoring its own radio series. ${ }^{182}$ The organized bar's concern with radio initially focused on the broadcasts of actual court proceedings, particularly the sensational coverage of the 1935 trial of Bruno Hauptmann for the kidnapping and murder of Charles Lindbergh's son. ${ }^{183}$ In 1936, however, the creation of a new vehicle for disseminating legal advice over the airwaves sparked the attention of the organized bar. The focus of the legal profession's wrath was a radio talk show from New York City called the Good Will Court.

United States 1933-53 (1968); J. Fred MacDonald, Don’t Touch That Dial!: Radio PROGRAMMING IN AMERICAN LIFE, 1920-1960 (1979).

182. The ABA had obtained free radio time from Columbia Broadcasting for a series of weekly radio addresses by former ABA presidents and such legal luminaries as John Wigmore, Karl Llewellyn, and Felix Frankfurter. See "The Lawyer and the Public" Is Title of Coming Radio Series, 19 A.B.A. J. 1, 1 (1933) (describing the radio series, the stated purpose of which was "to acquaint the layman with the efforts being made by the bar to improve the administration of justice and to show the great difficulties which lie in the way of this task").

183. The ABA had begun to lobby for restrictions on radio broadcasts of court proceedings even before the sensationalism surrounding the Hauptmann trial. On March 21, 1932, the Committee on Professional Responsibility had issued Formal Opinion 67, noting that a recent murder trial had been broadcast directly from the courtroom and stating that "[u]sing such a trial for the entertainment of the public or for satisfying its curiosity shocks our sensibilities." ABA Comm. on Professional Ethics and Grievances, Formal Op. 67 (1932), reprinted in AMERICAN BAR ASSOCIATION, OPINIONS OF THE COMMITTEE ON PROFESSIONAL ETHICS 311 (1967 ed.) [hereinafter ABA OpINIONs]. At its 1932 Annual Meeting, the ABA adopted a resolution decrying the broadcasting of judicial proceedings on the radio as a breach of decorum because "the practice had attained such proportions throughout the country that it seemed desirable to ask the Association to express itself in no uncertain terms." See Broadcasting of Judicial Proceedings from Court Rooms Condemned, 18 A.B.A. J. 762,762 (1932). After the Hauptmann trial, the ABA adopted Canon 35 as part of its Canons of Judicial Ethics, banning cameras and microphones from courtrooms. See David A. Harris, The Appearance of Justice: Court TV, Conventional Television, and Public Understanding of the Criminal Justice System, 35 ARIZ. L. REV. 785, 798 (1993) (linking the "circus-like and disruptive" presence of the media at the Bruno Hauptmann trial to the subsequent enactment of Canon 35). As adopted on September 30, 1937, Canon 35 provided:

Proceedings in court should be conducted with fitting dignity and decorum. The taking of photographs in the court room, during sessions of the court or recesses between sessions, and the broadcasting or televising of court proceedings are calculated to detract from the essential dignity of the proceedings, distract the witness in giving his testimony, degrade the court, and create misconceptions with respect thereto in the mind of the public and should not be permitted.

CANONS OF JUdicial ETHICs Canon 35, reprinted in ABA OpINIONS, supra, at 227. The ABA amended Canon 35 in 1952 to include television coverage within its prohibition. See id.; see also Harris, supra, at 798 n.103. 
The Good Will Court was the brain child of A.L. Alexander, a former police reporter turned radio announcer. ${ }^{184}$ Alexander initially sought out defendants in local courts to appear on his radio show, and then found judges, and later lawyers as well, to give legal advice on the air to the participants. ${ }^{185}$ Self-described as "a radio program which brings the drama and human appeal of real legal cases told by the people involved to real judges sitting unofficially," Will Court quickly became "a sensation." Good Will Court reportedly received fourteen thousand cases from the radio audience and presented thirty-two hundred of them to the panel. ${ }^{188}$

To get a flavor of the appeal of the Good Will Court and to see how closely it resembles online sites like Dear Esquire, consider the

184. See John Dunning, Tune in Yesterday: The Ultimate Encyclopedia of OldTIME RADIO 1925-1976, at 241-42 (1976). Alexander is said to have been motivated by his early experiences as a police reporter, where he had "seen first-hand the inequities of the legal system." Id. at 242. Another report asserts that Alexander's inspiration came when he served as an announcer for broadcasts by Tom Noonan, Bishop of Chinatown:

As announcer of that program Alexander watched the Sunday gatherings of downand-outers, the downcast and the hopeless, and out of it came the conviction that a human interest program, conducted for the sole purpose of giving friendly aid, free from the severe and sometimes terrifying atmosphere of the constituted courts would be a boon to thousands, besides providing a vivid and convincing picture of the frailties of some of our outmoded laws.

J. Arnold Farrer, Broadcasting-Good Will Courts, B. Bull. Boston B. Ass'N, Feb. 1937, at 12. It is not clear whether the Good Will Court was the first radio program of its type. One historian records that a radio show called the True Story Court of Human Relations ran on the NBC network in 1935, but he does not describe the nature of this program. See 2 BARNOUw, supra note 181 , at 109 .

185. See DunNING, supra note 184, at 242. Alexander first aired the program on March 31, 1935, on WMCA in New York City. See id. When his first program drew no response, Alexander began to seek out defendants in city courts to ask them to discuss their problems on the air anonymously. See id. He successfully obtained two New York judges, Jonah J. Goldstein and Pelham St. George Bissell, who was President Judge of the New York City Municipal Division. See id. More than 40 judges, participating in pairs, are said to have taken part in the Good Will Court during its brief lifespan. See id. One member of each pair of judges was an expert on domestic relations and the other an expert on civil litigation. See Court Drama Wins Network, N.Y. TIMES, July 26, 1936, § IX, at 10. For their services, the judges received a fee, which was to be contributed to charity. See id.; Good Will Court Quits Broadcasts, N.Y. TIMES, Dec. 19, 1936 , at 8 .

186. Court Drama Wins Network, supra note 185, § IX, at 10.

187. DUNNING, supra note 184 , at 242 .

188. See Court Drama Wins Network, supra note 185, § IX, at 10. The numbers seem exaggerated at best, as they suggest that the Good Will Court considered more than 60 cases on each weekly program. 
picture painted by Mitchell Dawson, a caustic critic of the program, who also happened to be the chair of the Committee on Public Relations of the Chicago Bar Association:

"Judge, your honor, he only seems to be happy when he makes me miserable. I don't care for myself, but he beats the little girl ...."

"Your honor, I invested $\$ 1600$ in a manufacturing business, but I can't get any accounting...."

"I was married, your honor, and couldn't get along with my motherin-law. She believed in spirits, and one night my husband accused me of witch-craft ...."

"Your honor, judge, I married a girl out of a barroom. I tried to make a good girl of her, but couldn't and left her ...."

"Your honor, I've written a book. It's fiction. It's life. It's a very good book and I want to protect it ...."

"My wife ate lobster in a restaurant, your honor, and it made her ill. We made a claim, but the insurance company turned us down ...."

One by one they parade before the microphone and tell their troubles to a judge - two judges - who hold a pseudo court in a broadcasting studio in New York City. A suave impresario marshals them, keeps their recitals within bounds, and elicits advice from one of the judges. ${ }^{189}$

The "suave impresario" was Alexander himself, who served as "mediator" in the presentation of cases to the judges. ${ }^{190}$

189. Mitchell Dawson, Good Will for Lawyers, 22 A.B.A. J. 862, 863 (1936). Dawson's description of the proceedings appears to be reasonably accurate. In fact, an advertisement for the Good Will Court that ran in the Sunday New York Times a week after its network premiere included the following sample questions: "Shall I leave my husband?"; "Can my landlady turn me into the street?"; and "Can my husband take my child from me?" N.Y. TIMES, Sept. 27, $1936, \S \mathrm{X}$, at 10.

190. See Court Drama Wins Network, supra note 185, § IX, at 10. One reviewer noted: "[N]ature has given him the ideal type of voice[,] somewhat ministerial and full of the intonations of sympathetic understanding, that fits the words to the role he plays, as sort of interlocutor between litigant and judge." Orrin E. Dunlap Jr., Tribunal of the Air, N.Y. Times, Sept. 27, $1936, \S \mathrm{X}$, at 10 
Several aspects of the Good Will Court should be noted. First, the identities of the participants were kept confidential. ${ }^{191}$ Second, the advice was given openly, over the airwaves, after each participant recited his tale of woe. Finally, even at this early date, the issue of disclaimers had already arisen, although the language used was far less technical than that which one would see today on a website. The Good Will Court ran this disclaimer at the beginning of each broadcast: "Neither to listeners nor applicants does this Court supplant the need for a lawyer's advice. To those who come here it supplies kindly and understanding guidance. To listeners it presents, in vivid human terms, a cross-section of the great system of justice which protects us all." ${ }^{192}$ At the conclusion of each broadcast, the announcer proclaimed: "May we remind you, too, that different sections of the country have different laws-and each legal case is affected by special circumstances. So may we emphasize the fact that you need the services of a lawyer for every legal problem.",

Many lay commentators applauded this "ethereal clearing house for human problems" $" 194$ as a public service. ${ }^{195}$ As a New York Times article described it:

The court, as a social service, is a free tribunal, which aims to help prevent crime by publicizing the laws. It is open to all comers who have a legal problem of universal appeal, aids people in solving domestic troubles and in finding legal redress for wrongs. The judges who are presiding for the evening hear the angles of the respective cases which the persons before the court present, and then make recommendations as to the best courses for the persons to follow. ${ }^{196}$

The Times also reported that twenty welfare organizations had followed up on the cases to see that they were "brought to a fair conclusion." 197

191. See DunNING, supra, note 184, at 241.

192. Farrer, supra note 184, at 12.

193. Id.

194. Court Drama Wins Network, supra note 185, § IX, at 10.

195. See, e.g., DuNNING, supra note 184, at 241 ("Good Will Court offered free legal help to the poor long before legal aid societies and public defenders became fashionable."); SAM J. SlATE \& JOE COOK, IT SOUNDS IMPOSSIBLE 130 (1963) ("This was one of the greatest services ever offered on radio. And it was free. Too much so.").

196. Court Drama Wins Network, supra note 185, § IX, at 10.

197. Id. One account reported that "Alexander's staff answered all mail, giving free advice even to those who weren't invited to appear; some 6,000 people were helped in the first year 
The Good Will Court became so popular that NBC acquired the show for national distribution in July 1936. The program was to air on Sunday nights from 8:00 to 9:00 p.m., ${ }^{198}$ sponsored by Chase \& Sanborn Coffee. ${ }^{199}$ The program "made compelling radio," and its ratings soared soon after its NBC premiere on September 20, $1936 .{ }^{200}$ Despite its great success, ${ }^{201}$ however, the program was destined to run only

alone." DUNNING, supra note 184 , at 242 . These reports seem highly exaggerated and suggest that Alexander's genius at promotion included not some small measure of puffery.

198. Court Drama Wins Network, supra note 185, § IX, at 10. Apparently a local version of the program continued on WMCA on Wednesdays at 10:00 p.m. See Good Will Court Quits Broadcasts, supra note 185 , at 8 .

199. See DunNing, supra note 184, at 242. One measure of its success may be that it replaced the very popular Major Bowes Amateur Hour in its coveted Sunday evening time slot from 8:00 p.m. to 9:00 p.m. See Court Drama Wins Network, supra note 185, § IX, at 10. A review in the New York Times that ran the week after the Good Will Court's premiere quipped: "When Major Bowes and his amateurs did not keep their rendezvous with the Sunday evening microphone for some listeners no doubt it was almost as if the sun had failed to rise on schedule." Dunlap, supra note 190, § X, at 10.

200. DunNING, supra note 184, at 241. Its premiere was not without controversy, as New York City Municipal Court Judge Nathan Sweedler threatened a lawsuit for the unauthorized use of the name "Good-Will Court," which he claimed to have originated in Brooklyn in 1927. See 'Court' on Air Faces Suit over Its Name, N.Y. TIMES, Sept. 20, 1936, § II, at 12. He asserted that A.L. Alexander had sought use of the name for noncommercial purposes, but had then made a commercial program appropriating the name. See id. Judge Sweedler further claimed: "The 'Good-Will Court' has been conducted by me and many others who gave their time free without a thought of commercialization." Id. The case, in which Judge Swindler had sought $\$ 250,000$ in damages, ultimately was dismissed for lack of injury on March 9, 1937, several months after the program had been cancelled. See Good-Will Court Loses, N.Y. TIMES, Mar. 10,1937 , at 4

201. The novelty of the Good Will Court, coupled with the fact that it had displaced one of the most popular programs on the air, Major Bowes' Amateur Hour, was newsworthy enough to merit a lengthy review in the Sunday New York Times the week after its network premiere. The review amplified further the emotional content of the Good Will Court:

The litigants are not rehearsed; they play roles in the actual drama of life for which there are no scripts. Fate assigns the roles. The actors live and play the parts as no trained radio performer could. The heart-breaks, the nervousness, tears, tragedy and helpfulness, uncannily are electrified and can be sensed far beyond the microphone.

Dunlap, supra note $190, \S \mathrm{X}$, at 10 . The generally favorable review continued:

This tribunal of the air claims a lofty purpose, to do good in administering to human welfare, but the benefits may go far outside the studio walls. These radio waves are a mirror of life. The solution of an unfortunate person's problem is but a small part of the good-will spread by the court.

$I d$. Reflecting common concerns of the Depression era, the reviewer continued:

After attending the Good-Will Court on the air there are thousands no doubt suddenly thankful for the good things in life which they possess, but which others have missed. The court, if it achieves nothing else, is certain to brush aside grumbling and discontent. This broadcast reveals the load the neighbor is carrying, and it is likely to 
three months before its cancellation, under heavy pressure from the legal profession. ${ }^{202}$

As the success of the Good Will Court quickly spawned a number of local copycat broadcasts, ${ }^{203}$ the organized bar began to mobilize against the proliferating radio courts. The battle was fought on two fronts-at the county and national levels. At the county level, the powerful New York County Lawyers' Association ${ }^{204}$ approved a report by its special committee denouncing the Good Will Court. ${ }^{205}$ The committee's report recommended that the Appellate Division adopt a rule banning participation by lawyers in such activities. ${ }^{206}$ The committee's scathing critique is worth reviewing at some length, as its points are reiterated in later opinions. One concern raised was the lack of confidentiality. ${ }^{207}$ Another concern was the inadequacy of the

make those who eavesdrop more tolerant and encourage them to lend a helping hand.

Id. The program was seen as having educational value, particularly for "many students of law, for the broadcast puts them in touch with noted judges hearing actual cases." Id. The reviewer also surmised: "And no doubt there are countless lawyers listening-in, exactly as orchestral conductors eavesdrop on their colleagues and rivals." Id.

202. At the time of its cancellation, the Good Will Court was broadcast over 66 different channels in 39 different states. See Rosenthal v. Shepard Broad. Serv., 12 N.E.2d 819, 820 (Mass. 1938).

203. It is difficult to determine how many similar radio programs appeared after the Good Will Court's premiere. A resolution by the California Bar criticizing the Good Will Court mentions the emergence of radio courts in San Francisco and elsewhere. See Alfred Bartlett, The President's Message, 11 STATE B.J. ST. CAL. 267, 267 (1936) ("It is improper for a former Judge or an attorney to participate in, or permit the use of his name in a commercially sponsored radio program ...."). The Rosenthal opinion discusses both the Good Will Court and a Boston variation called the Court of Common Troubles. See Rosenthal, 12 N.E.2d at 820. See also ABA Comm. on Professional Ethics and Grievances, Formal Op. 166 (1936), reprinted in ABA OPINIONS, supra note 183, at 436.

204. The New York County Lawyers' Association, with 6,000 members, was the largest voluntary organization of lawyers in the United States other than the ABA. See William L. Ransom, Which Road for the Legal Profession, 22 A.B.A. J. 21, 21 (1936). A recent survey of the economic condition of its membership had shown a substantial downturn, largely due to the Depression, with nearly half the lawyers in New York County reporting an annual income below the "respectable minimum family subsistence" of $\$ 2500$ a year. Committee on Professional Economics of New York County Lawyers Association Recommends Aggressive Effort to Relieve Overcrowding and Improve Economic Conditions of Lawyers, 22 A.B.A. J. 439, 440 (1936).

205. See Lawyers Ask Ban on Radio 'Court', N.Y. TIMES, Nov. 11, 1936, at 12. The committee had consulted with representatives of the Association of the Bar of the City of New York, the Bronx County Bar Association, the Brooklyn Bar Association, the Queens County Bar Association, the Nassau County Bar Association, and the Legal Aid Society. See id.

206. See id.

207. See id. ("While the identity of the so-called litigant is not published, other persons interested in the controversy can, of course, identify him by listening on the radio."). 
advice given as a "snap judgment." ${ }^{208}$ A third objection was the lack of dignity inherent in such proceedings, as they exploited "morbid curiosity." ${ }^{209}$ There were also worries that uninformed listeners might erroneously rely on the advice given. ${ }^{210}$ Perhaps most noteworthy is the committee's description of its motives:

The attitude of members of the bar to this program is not due to any belief that their practice is in the remotest way affected by these operations. They are interested, however, in its legal and ethical aspects. The conduct of litigants in these broadcasts frequently indicates their belief that they are really appearing before a court. When wrong advice is given, the litigant apparently has no recourse where he has been misguided. ${ }^{211}$

Not only did the committee flatly reject the notion that the program had any educational value, but it also asserted that judges on the program were "using the power of their office and the influence of their names to promote the business interests of others, in viola-

208. Id. ("The presentation is one-sided. There is no opportunity to obtain a complete statement of the facts and the judge has practically no opportunity to check the correctness and the soundness of his snap judgment.").

209. Id. The New York Times described the scene further:

The judge attempts to give advice. He is frequently interrupted, and even corrected, by the conductor. . . . The advice is accompanied by the announcer's solicitation to purchase the sponsor's coffee. ... The broadcast is conducted primarily for commercial purposes, to exploit a morbid curiosity in the private woes and tribulations of the so-called litigants.

Id.

210. See id. ("Listeners-in from other States are completely misled, in so far as the laws of their States are concerned, by the unconsidered advice glibly given over the radio under the conductors' guidance.").

211. Id. Another New York City bar association asserted:

Educational and sociological benefits do not result from the exploitation of the woes and troubles of any individual by converting them to the entertainment and amusement of thousands; by presenting one side of a problem; by rendering an opinion on the law, as it obtains in one state, to listeners in forty-eight states, many of whose laws are at variance; by giving advice of doubtful practical value, since the inquirer must ultimately see a lawyer or have his problem decided by a duly constituted court. From the lawyers' viewpoint the publicizing of answers on specific legal problems, as in the broadcast referred to, does not carry with it the relationship of attorney and client, with its resulting responsibility, and the conversion of serious, personal legal problems into entertainment and amusement tends to diminish the respect for courts and judges and impair the dignity of the bench and bar, and is therefore objectionable.

Meeting of the Council, B. Bull. Boston B. Ass'N, Jan. 1937, at 16 (quoting a statement by an unidentified New York City bar association). 
tion of the spirit and intent of the ABA's Canon of Judicial Ethics." ${ }^{212}$ In another opinion issued that year, the committee raised similar objections to a proposed radio program that would answer legal questions that had been mailed in by listeners. ${ }^{213}$

Despite mounting pressure, the Good Will Court continued to make its case. Chase \& Sanborn filed in the Appellate Division a brief objecting to the proposed rule. ${ }^{214}$ It argued that the court was "distinctly educational in its content and in the manner in which the

212. Lawyers Ask Ban on Radio Court, supra note 205, at 12. The committee focused on Canon 25, adopted in 1924, which provided:

[A judge] should avoid giving ground for any reasonable suspicion that he is utilizing the power or prestige of his office to persuade or coerce others to patronize or contribute, either to the success of private business ventures, or to charitable enterprises. He should, therefore, not enter into such private business, or pursue such a course of conduct, as would justify such suspicion, nor use the power of his office or the influence of his name to promote the business interests of others; he should not solicit for charities, nor should he enter into any business relation which, in the normal course of events reasonably expected, might bring his personal interest into conflict with the impartial performance of his official duties.

CANONS OF JUdicial ETHICs Canon 25 (1956). Furthermore, the committee opined that lawyers and ex-judges participating in such programs also violated Canon 40 of the Canons of Professional Ethics, adopted in 1928, which provided: “A lawyer may with propriety write articles for publications in which he gives information upon the law; but he should not accept employment from such publications to advise inquirers in respect to their individual rights." CANONS of Professional ETHICs Canon 40 (1956).

213. The New York County Lawyers' Association Committee on Professional Ethics issued an opinion in response to Question No. 340, asking about the propriety of attorneys' participating in programs about legal oddities in questions and answers by lawyers appearing for commercial sponsors. See New York County Lawyers' Ass'n Comm. on Prof'l Ethics, Op. 340 (1937). The format of the proposed program differed somewhat from that of the Good Will Court, in that listeners would be asked to mail in questions and "[t]hose questions of general interest [would] be answered on the following week's broadcast, those not of general interest [would] be answered by mail, not on the stationery of an attorney, but on the letterhead of the program, 'Your Attorney,' or 'The Unknown Attorney.'” Id. The opinion stated:

[A] lawyer is not justified in giving an opinion without an opportunity to obtain from his client adequate information as to the facts in his client's case and the documents which the lawyer may deem material ... nor can the client be safe in acting on generalizations. ... [O]thers ... may be misled into accepting the published question and answer as applicable to their own problem.

Id. The opinion also noted that there might be concerns about unauthorized practice of law and that its ethical concerns were not alleviated by the participating attorneys' anonymity, because it "tend[ed] to diminish the sense of personal responsibility of the attorney to the person so inquiring." Id.

214. See Radio Court Held Benefit to Public, N.Y. TIMES, Dec. 4, 1936, at 22. Chase \& Sanborn and its advertising agency, J. Walter Thompson Company, were represented by former U.S. Attorney Charles H. Tuttle; A.L. Alexander was represented by prominent litigator Louis Nizer. See id. 
content [was] presented," and that it "serve[d] to accomplish effectively and on an incomparable scale one of the objects which bar associations ha[d] recently been urging - to wit: the popularizing of the law." 215 Asserting a ringing defense of the First Amendment (and a thinly disguised slap at lawyer self-interest), the brief continued:

To shut off this method of speech, this medium of education and this incitement to public thinking would be a gross interference with the freedom of speech and of thought. To do so on purely technical and legalistic grounds and for the fancied benefit of some particular class would be to deny fundamental rights and to restrict the liberties and opportunities of the whole community.... If such a force as this for social betterment is contrary to law, then there is something wrong with the law. ${ }^{216}$

Nevertheless, the debate over giving legal advice on the radio soon reached national attention, as other state bars joined the call for cancellation of the Good Will Court and its progeny. ${ }^{217}$

215. Id.

216. Id. Letters of commendation were attached to the brief from a variety of lawyers and politicians, most notably New York Governor Herbert Lehman, who stated that the Good Will Court broadcasts "serve[d] a very real purpose in bringing to people a better understanding of the scope and purpose of our courts and of our laws." Id. Attorney General John J. Bennett was quoted as saying: "The practice of having members of the local judiciary answer and advise is to be commended.... The idea of the broadcast is a most humane one, since here is provided a great system of public education." Id. Other letters were received from legislators and city officials, including both the governor and attorney general of New Jersey. See id.

217. The State Bar of California passed a resolution strongly disapproving of the Good Will Court and local radio courts broadcast in San Francisco and Los Angeles as "contrary to the best traditions of the bench and bar and the dignity and high standards of the judiciary." Bartlett, supra note 203, at 267. Describing the participation of lawyers and judges who, "after listening to tales of human misery, publicly gave them legal advice," the president of the State Bar of California's message accompanying the resolution noted that "nothing could be more calculated to bring the judiciary and the legal profession into disrepute." Id. Its resolution said: "[I]t is therefore resolved that such radio programs and such conduct by judges and lawyers is strongly disapproved and that it is earnestly urged that it be discontinued." Id.; see also Dawson, supra note 189, at 863 (discussing lawyers' opposition to the Good Will Court). The president further noted: "An encouraging sign is that most of the lawyers and judges in this State needed only to hear it suggested to them that such a program might be in bad taste, to cause them to discontinue their participation in such programs." Bartlett, supra note 203, at 269. The Boston Bar Association joined the battle and adopted the resolutions of the ABA and the New York County Lawyers' Association. Surprisingly, one of its members had actually recommended that the Bar Association consider sponsoring a "Radio Legal Clinic" like the Good Will Court. See The Annual Meeting, B. Bull. Boston B. Ass'N, Nov.-Dec. 1936, at 7-9. Instead, the bar adopted a resolution condemning such courts. See Meeting of the Council, supra note 211 , at $15-16$. 
On the national level, the influential ABA Committee on Professional Ethics and Grievances entered the fray in November 1936, issuing a formal opinion that reiterated the New York County Lawyers' Association's position that judges should not participate in such a program. ${ }^{218}$ Much of ABA Formal Opinion 166 decried the lack of dignity involved in such a commercialized format. ${ }^{219}$ The opinion also expressed concern that "[b]ecause of the divergence in the laws of the several states the advice given by the judge [was] apt to be misleading to listeners in states other than in the state of origin." 220 Furthermore, the advice might mislead the lay public, "since the 'clients' and those who listen to these programs may think they are getting advice of a duly constituted court." ${ }^{221}$ Furthermore, "the "clients' have no recourse when they have been wrongly advised."222 Although the opinion acknowledged that the "announced purpose" of this radio program was "to afford to indigent persons, unable to pay for the services of attorneys, means of securing advice with respect to their legal problems from judges of courts which are an integral part of the judicial system of the state, and to "inform the public," it sarcastically noted: "The obvious purpose is to promote the sales of the advertiser's product." ${ }^{, 23}$ By participating in such programs, the opinion averred, lawyers and judges "lower the esteem of the profession" and "stir up legal strife."224

218. See ABA Comm. on Professional Ethics and Grievances, Formal Op. 166 (1936), reprinted in ABA OPINIONS, supra note 183, at 437 ("It is the unqualified opinion of this committee that no judge or former judge nor any other member of the Bar should participate in any such commercial program.").

219. See id. The opinion noted: "At the outset we deprecate the simulation of an actual judicial proceeding by a group of lawyers or judges, and especially one having for its primary purpose the advertising of an article of commerce. It is an affront to the dignity of judicial tribunals and should not be tolerated." Id. In particular, the opinion criticized the "emotional outbursts of the "clients," worrying that laypeople [would] believe that "usual court procedure [was] being followed." Id. at 436.

220. Id. at 437.

221. Id. The committee concluded: "Our present economic structure justifies the maintenance by the organized bar of the modern legal aid clinic to aid the individual lawyer in the discharge of his obligation, but cannot justify its alleged counterpart in the commercial field of radio entertainment." Id.

222. Id.

223. Id. at 436 .

224. Id. at 437. 
A week later, the ABA's Committee on Unauthorized Practice of Law also weighed in with its own criticism of radio courts. ${ }^{225}$ It complained:

By statutes and common law principles, corporations and nonlawyers are forbidden to furnish legal advice and service because of the danger to the public, just as 'quack' doctors are prohibited from practising medicine, and the radio is thus being misused in a manner which in many states would be clearly unlawful and improper. This is particularly so in view of the fact that people asking advice through this 'Good Will Court' are entirely deprived of the usual accepted safeguards and protections to which they are entitled and, if misled, have no recourse against the sponsors or others connected with the program. ${ }^{226}$

Later that month, the $A B A$ Journal ran a column by the Chicago Bar Association's Mitchell Dawson, titled "Good Will for Lawyers." ${ }^{227}$ Dawson attacked the Good Will Court for creating an inaccurate portrait of the legal profession, noting: "The public is led to believe that lawyers are expensive and out of the reach of the average person. ... The impression is indirectly conveyed that the poor and unfortunate have no place to turn for free legal advice." 228 He also accused such programs of creating "good will" solely for the sponsors, rather than for the "unfortunates" who were receiving legal advice. ${ }^{229}$

225. The Committee had been first appointed in 1930. See Rhode, supra note 180, at 8 . The ABA's focus on unauthorized practice had emerged fully by 1936 . The same issue of the $A B A$ Journal that contained ABA Formal Opinion 166 also contained an article titled War Declared on Lawyers Aiding in the Illegal Practice of Law, 22 A.B.A. J. 887 (1936) [hereinafter Illegal Practice of Law]. That article briefly describes a combined effort by the Committee and the ABA's Committee on Professional Ethics and Grievances to "stamp out the unauthorized practice of the law that both the welfare of the public and that of the profession require." Id. The article further notes: "When a lay agency engages in the practice of law, it nearly always has the cooperation of a lawyer. In fact, the assistance of a lawyer is indispensable to such practice." Id.

226. See Illegal Practice of Law, supra note 225, at 887.

227. See Dawson, supra note 189 , at 863.

228. Id. He continued: "The Good Will Court is a voice which by implication says to a multitudinous radio audience that the lawyers have failed in their duty to society." Id.

229. Id. Dawson further declared:

The good will which the Good Will Court seeks to engender is obviously good will for its sponsor-a corporation in the business of selling a certain commodity. The legal advice, which it so benevolently dispenses to the unfortunates who apply for it, is paid for magnificently in sales of the sponsor's merchandise.

Id. He concluded: 
An even harder blow to the Good Will Court was soon to follow. In December 1936, the Appellate Division of the New York Supreme Court acceded to the demand of the New York County Lawyers' Association and issued a new rule for lawyers admitted to practice in New York City and surrounding counties that would "prohibit them from taking part in 'good-will courts' broadcast over the air." 230 The rule itself did not expressly mention radio "courts," but provided:

No attorney shall advise inquirers or render any opinion to them through or in connection with a publicity medium of any kind in respect to their specific legal problems, whether or not such attorney shall be compensated for his services. Any attorney who violates the rule shall be deemed to be guilty of professional misconduct. ${ }^{231}$

Although Alexander kept up a brave front, insisting that the Good Will Court would continue to be broadcast, ${ }^{232}$ the New York Appellate Division's ban on appearances by lawyers and judges sounded the death knell for his program. The cancellation of the Good Will Court was announced two days later ${ }^{233}$ and the New York County Lawyers' Association claimed a resounding victory. ${ }^{234}$

Lawyers assure one another at bar association meetings that they must maintain their traditions, ideals, duties and responsibilities. These are truisms that are "gone with the wind." What we need to show is a picture of the lawyer in action, the lawyer as hero, if you please, but a very human practical hero, whose services to his clients and to society are personal, concrete, obvious and invaluable.

Id.

230. Lawyers Barred on Radio 'Courts', N.Y. TIMES, Dec. 17, 1936, at 29.

231. Quarterly Review of Decisions: Radio, 9 AIR L. REV. 297, 300 n.9 (1938).

232. See Lawyers Barred on Radio 'Courts', supra note 230, at 29. Initial speculation had been that Alexander would have to obtain lawyers or judges from outside the area covered by the Appellate Division's rule, which included the five counties of New York City and the counties of Nassau, Suffolk, Westchester, Putnam, Duchess, Orange, and Rockland. See id. Instead, the December 16 program featured a sociologist giving advice. See id.

233. See Good Will Court Quits Broadcasts, supra note 185, at 19. In 1943, A.L. Alexander revived the program, without the participation of lawyers and judges, on the Mutual Network, as A.L. Alexander's Mediation Board. The program never attracted the same audience as the Good Will Court, but it ran in various formats until 1950. See DUNNING, supra note 184, at 242. Self-described "marital expert" John J. Anthony also capitalized on the sensation created by the novel format of a radio advice program, launching a new and wildly popular advice program called The Goodwill Hour, in which he dispensed with lawyers and judges and gave advice to unfortunates on his own. See id. at 242-43.

234. See Hughes Jr. Lauds Bar for Legislative Work, N.Y. TIMES, May 23, 1937, at 28. In the annual report of the New York County Lawyers' Association, President Charles E. Hughes, Jr., asserted: "[T]his program, publicizing legal advice to individual inquirers in connection with commercial advertisements, was contrary to the public interest, since it was misleading to the public and brought both the bench and the bar into disrepute." Id. The battle was far from 
Although the battle had been won, the ABA continued its quest to eradicate what it deemed the unauthorized practice of law. At its annual meeting in 1937, the ABA approved Canon 47, "Aiding the Unauthorized Practice of Law," which reads: "No lawyer shall permit his professional services, or his name, to be used in aid of, or to make possible, the unauthorized practice of law by any lay agency, personal or corporate." ${ }^{235}$ The ABA also waged an open campaign to encourage state and local bar associations to stamp out unauthorized practice. ${ }^{236}$ Although the extent to which the Canon was prompted by the recent attack on radio courts is unclear, it is likely that at least part of the concern over the dispensing of free legal advice over the air waves might have been related to the economic considerations that spurred concern about the unauthorized practice of law.

Yet another blow to the phenomenon of radio courts came over a year after the cancellation of the Good Will Court, when the Supreme Judicial Court of Massachusetts considered a challenge to radio courts in Rosenthal v. Shepard Broadcasting Service. ${ }^{237}$ In November 1936, less than two weeks after the ABA issued Formal Opinion 166, three members of the Massachusetts bar sued the broadcaster of the Good Will Court and a local variant called the Court of Common

over. In early 1937, the Judicial Council of New York recommended to the New York Legislature that it adopt a statute banning the use of the word "court" in the name of enterprises purporting to be legal proceedings, explaining:

"It has been forcibly brought to the attention of the Judicial Council that a large portion of the public believe [sic] that these proceedings represent a real court, real cases, real litigants, and real decisions by real judges. This impression cannot be removed unless the use of the word 'court' is discarded and it is essential in order that the true administration of justice may not suffer severely, that the possibility of misunderstanding be removed."

Judicial Council for Women Jurors, N.Y. TIMES, Jan. 15, 1937, at 2 (quoting the Judicial Council). The Commission proposed adoption of the following statute:

No person, corporation, joint stock association, or any other body except the courts organized under the judicial system of the United States, or of this state, or any political subdivision thereof, shall use the word 'court' in a name or title, or hold itself out to be a court, so as to give to the public the impression that it is a part of the duly organized judicial system of the United States or of this state or any political subdivision thereof.

State of New York, Third Annual Report of the Judicial Council of the State of NEW YORK 35 (1937). The Council also recommended adoption of ethical rules designed to enforce these proposed statutes. See id.

235. CANONS OF PROFESSIONAL ETHICs Canon 47 (1956).

236. See WOLFRAM, supra note $98, \S 15.1 .1$ at 825.

237. 12 N.E.2d 819 (Mass. 1938). 
Troubles $^{238}$ under a 1935 state statute that banned corporations from " "giv[ing] legal advice in matters not relating to [their] lawful business, or practic[ing] law.", 239

By the time the court issued its opinion in Rosenthal, both the Good Will Court and the Court of Common Troubles had been discontinued, and "the inference seem[ed] strong ... that there [was] no likelihood that these programs [would] be resumed by the respondent." ${ }^{240}$ Nevertheless, the court asserted that these programs constituted the unauthorized practice of law under the Massachusetts statute, explaining: "The giving of advice as to legal matters has been commonly recognized as an important part of the activities reserved for members of the bar and constitutes the practice of law." ${ }^{241}$ Moreover, the court concluded that giving legal advice on these talk shows "not only violate[d] the confidential relation of an attorney and client but [was] inconsistent with the traditional standards of the bar and the courts." ${ }^{242}$ The court rejected the argument that such radio programs provided a public service to those who could not afford legal assistance, asserting: "There is no finding that the persons seeking

238. Like the Good Will Court, the Massachusetts radio court invited individuals to submit questions in advance for response from a panel of active judges. See id. at 820 . The court noted:

Most of the cases stated involved questions of civil rights and liabilities and were of a nature usually dealt with by practicing attorneys in the course of giving advice to clients in office consultation and by judges of trial courts in the consideration of cases before them while on the bench.

Id. The advice given addressed a wide range of matters:

$[\mathrm{P}]$ roper registration of an automobile, remedies for nonpayment of rent by a tenant, the right of an administratrix to recover possession and control of personal property belonging to the estate, the claim of a tenant for fixtures installed by him, the right of a young woman to an engagement ring after termination of the engagement, and divorce.

Id. The Court of Common Troubles also featured a disclaimer similar to that read on the Good Will Court, stating that "the opinions to be expressed on the cases presented were to be based on the law of Massachusetts, and that there was no intention to offer legal advice as a substitute for that given by attorneys." Id. at 821 .

239. Id. (quoting MASS. GEN. LAws ch. 346, § 1 (1935)).

240. Id. at 821. The Court of Common Troubles was last broadcast on December 19, 1936, and the Good Will Court was last broadcast on December 20,1936. See id. The court noted that "[t]he circumstances attending [their] discontinuance [were] not set out with much fulness in the record." Id. at 821 .

241. Id.

242. Id. The ABA Journal reported this opinion in April 1938, and noted that a lawyer's participation in such a broadcast might violate newly adopted Canon 47. See Lawyers Participating in Radio Broadcasts May Violate Canon 47, 24 A.B.A. J. 334, 334 (1938). 
and receiving such advice were indigent. There is an express finding that the respondent was conducting these programs as part of its commercial adventure for profit. There is no finding that the motives of the respondent were charitable." 243 Contemporary commentary on Rosenthal suggested that it had established that "all radio broadcasts as a part of which attempts are made to give legal advice, or to accomplish the equivalent thereof by means of fictitious and unreal courtroom scenes or simulated trial procedure" were "contrary to the public interest." 244

Despite the apparent authoritativeness of its holding, the Rosenthal decision did not end the phenomenon of radio courts permanently, as at least one more reported decision addressed the issue. A 1939 opinion of a lower New York City court refused to enforce an arbitration award stemming from a radio program called the Jewish Court for Peace and Justice. ${ }^{245}$ The judge explained: "Anyone who has ever listened to one of these 'trials' on the air knows the sketchy character of the testimony, the impatience of the master of ceremonies, and even the arbitrators, due to the exigency of the shortness of the time allotted for each trial." 246 The court continued:

I have listened to a number of such programs on the air, and the ignorance of those in charge of the commonest principles of law was appalling. Atrocious advice has been given to poor ignorant people, which could serve only to multiply the trouble they have brought to these mountebank "courts." In the beginning a few men learned in the law permitted themselves to be used in connection with this "swing time justice" until they realized the iniquity of the scheme. Today no judge or self-respecting lawyer will lend himself to the capitalization of human misery. . . . Certainly, no good is accomplished for the poor litigants who are beguiled into making their

243. Rosenthal, 12 N.E.2d at 821.

244. Quarterly Review of Decisions: Radio, supra note 231, at 300-01 \& n.9 ("The cases have been practically unanimous in including in the definition of 'practice of law' the giving of legal advice and counsel by attorneys to their clients. These are the very functions that attorneys appearing in the 'Good Will Court' have been performing."); see also Current Comment: Radio, 8 AIR L. REV. 46, 48 (1937) ("It is submitted that since a radio sponsor cannot directly practice law, not being a member of the bar, it cannot engage attorneys to advise on legal problems without being guilty of the illegal practice of law.").

245. See In re Blake, 17 N.Y.S.2d 496, $496-97$ (Sup. Ct. 1939). In that case, the 20-year-old daughter of the defendant had been enticed into appearing on the air and had signed an agreement purporting to bind her father to pay whatever award the radio "arbitrator" deemed appropriate. See id.

246. Id. at 497. 
troubles entertainment for the world, and assuredly, much harm is done. These 'courts' have no ability, no responsibility and no authority, and should, as a matter of public interest, be discour-

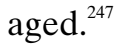

Although radio courts like the Good Will Court seem to have disappeared by the 1940s, disputes involving the use of the word "court" in other radio programs continued to arise sporadically. ${ }^{248}$

What lesson should lawyers of the twenty-first century take from the experiences of their Depression-era counterparts? On the one hand, lawyers can hardly quarrel with many of the concerns expressed by opponents of the Good Will Court. The existing legal precedent reviewed above demonstrates that giving specific legal advice to laypeople can create an attorney-client relationship, ${ }^{249}$ and that fact alone should dictate caution to lawyers who engage in such

247. Id. Soon thereafter, a bill was sponsored in the New York legislature to prohibit the use of the term "court" in certain broadcast programs. See Private Unauthorized Courts, 26 A.B.A. J. 502, 502 (1940).

248. The next radio program to incite the wrath of the ABA Committee on Unauthorized Practice was the Court of Missing Heirs. Created by attorney James Waters, the program presented two probate cases a week, seeking heirs to estates. See DunNING, supra note 184, at 148. It had first appeared in October 1937 in limited broadcast, and Waters had found his first missing heir within weeks. See id. By 1939 the program was broadcast nationally on CBS. See id. ("During its run, Waters found more than 150 heirs worth nearly $\$ 1$ million. Most had no idea they were anyone's heir, and many were rescued from the clutches of poverty."). Concerned about misleading the public, the ABA Committee on Unauthorized Practice of Law sought:

[to] induce the broadcasting stations in the United States, by agreement among themselves or in some other practicable way, to agree that hereafter a radio program should neither give or offer to give legal advice, nor by title or substance represent or lead the public to believe that it emanates from a court or is a part of the judicial system.

Edwin M. Otterbourg, Unauthorized Practice of Law, 27 A.B.A. J. 271, 271 (1941) ("The Committee believes that the use of the word 'court' in radio programs results in a misrepresentation of the judicial process over the air which is apt to lessen the respect for the administration of justice."). The Committee succeeded in obtaining the approval of the National Association of Broadcasters for this policy. On July 28, 1941, the National Association of Broadcasters issued a communication to its members suggesting that they refrain from the use of the word "court" as part of the title of a radio program. The title of the offending program was changed to Are You a Missing Heir? See Agreement Reached with National Association of Broadcasting, 7 UnAUthorized PRAC. NEws 47, 47-48 (1941). The ABA and various state and local bar associations commonly entered into agreements such as this until the 1970s, when new concerns about antitrust violations led to their rescission. See Rhode, supra note 180, at 10 n.36. Are You a Missing Heir? ran until 1942, and then was revived for one season in 1946. See DunNING, supra note 184, at 148.

249. See supra Part I. 
activity outside formally created relationships. The public spectacle of lawyers and judges participating in a program that seems to capitalize on human misery raises equally weighty concerns. In one sense, the story of the Good Will Court's demise is the tale of a selfless group of lawyers who, with the sole motivation of protecting innocent laypeople, put a quick end to a mockery of legal practice and, in so doing, restored some dignity to an already-tarnished profession. This is the official story of most attempts to eradicate the unauthorized practice of law. ${ }^{250}$ One can easily imagine a modern version of the story in which the organized bar awakens to the dire threat to civilization posed by unscrupulous online lawyers and drives them out of business.

Like all good stories, however, the tale of the Good Will Court has an alternative interpretation. In this version, the Good Will Court stands as an innovative use of modern technology to meet the widespread need for legal assistance in a time of great economic hardship. With the legal profession already threatened by a loss of business as a result of the Depression, newly powerful bar organizations could not tolerate any innovation that might eliminate the need for traditional legal services. The battle waged against the Good Will Court was part of a larger struggle to protect the traditional practice of law against other modern encroachments, reflected in the contemporaneous crusade against the unauthorized practice of law. ${ }^{251}$ Rather than symbolizing a victory for consumers of legal services, the death of the Good Will Court thus becomes a defeat, depriving laypeople both of

250. See Restatement (Proposed Final Draft No. 2), supra note 180, § $4 \mathrm{cmt}$. b ("The primary justification given for unauthorized practice limitations was that of consumer protection-to protect consumers of unauthorized practitioner services against the significant risk of harm believed to be threatened by the non-lawyer practitioner's inexperience or lack of ethical constraints.").

251. See HURST, supra note 178 , at 328 :

Against the challenge of unsatisfied needs for legal help, the record of the bar was one of long inertia. The organized bar did not originate the legal aid movement, and was slow to give it even limited support. The bar became concerned with lay competition, largely under the spur of lawyers' economic distress . . . and did little selfsearching, to find out wherein lawyers were so inadequately serving people that they should turn to other advisers.

See also ReSTATEMENT (Proposed Final Draft No. 2), supra note 180, $§ 4$ cmt. b ("Some consumer groups and governmental agencies have criticized some restrictions as over-protective, anti-competitive, and costly to consumers."). 
needed education about legal principles and of an inexpensive alternative to traditional attorney-client relationships. ${ }^{252}$

This story has been retold over and over again in the last sixty years. The bar prefers the tone of the first version, but laypeople may find the second more convincing. Like the story of the technophobic Clarence Seward, the saga of radio courts in the 1930s casts light on our current struggles with the use of technology in law practice today. Indeed, the campaign waged against the Good Will Court and its progeny reflects in microcosm the conventional approach taken with respect to legal advice-giving in nontraditional contexts. As the next sections will show, each time that lawyers have sought to adapt existing media to answer legal questions posed by laypeople, the organized bar has moved to regulate-potentially out of existencesuch activity. The question is whether we shall be able to write a new ending to the story for the Digital Age, as the legal profession grapples with the issue of Internet lawyers. Before turning to that issue, I shall review the other areas in which the bar has addressed the giving of legal advice in nontraditional settings.

\section{REgulAting LEGAL AdVICE IN NONTRADITIONAL CONTEXTS}

\section{A. Modern Regulation of Legal Advice on Radio and Television}

Although apparently put to rest by the battle over the Good Will Court, the issue of legal advice on radio and television broadcasts continued to arise sporadically. ${ }^{253}$ A 1938 ABA opinion allowed offi-

252. See HuRst, supra note 178 , at 325 :

The surveys showed ... that city people knew little of when it might be to their interest to seek legal advice, that they had no idea how to choose a lawyer, and that they were afraid to go to a lawyer because they had unfounded and exaggerated notions of what it would cost and what consequences would be involved.

253. In 1950, the ABA Journal published a letter sent to New York broadcasters from Edwin Otterbourg, Chairman of the New York County Lawyers' Association Committee on Unlawful Practice of the Law. The letter decried "certain broadcasts which have seemed to suggest that listeners, in dealing with their individual specific problems, could rely on off-hand information or advice, which was offered, or on answers which purported to give legal advice in response to specific inquiries." Edwin M. Otterbourg, Legal Advice by Radio, 36 A.B.A. J. 450, 458 (1950). He asserted that radio talk programs should be confined to "general information about the law" and noted: "Obviously, for a man to base his conduct or stake his fortune on advice given on a radio broadcast program, may lead to most unfortunate results, whether such advice be given by a lawyer or a non-lawyer; if given by the latter it may constitute a penal offense." Id. Moreover, "[t]he situation is rendered especially hazardous when it is considered 
cially sponsored "educational" presentations. ${ }^{254}$ But in the 1960 s, the ABA reiterated its general ban on giving individually tailored advice over the airwaves. In one informal opinion, the Committee on Professional Responsibility stated that lawyers could participate in a local radio quiz program and answer legal questions received from the public, but cautioned:

$[\mathrm{T}]$ he lawyer should not answer any question that undertakes to advise a particular member of the audience in regard to what he should personally do.... His participation in a panel discussion that had as its objective the furnishing of personal advice in the answering of questions would amount to a solicitation of professional employment. Furthermore, if a program is designed to answer the specific personal problems of individual laymen, the organization putting on the program may be engaged in the unauthorized practice of law, and, if so, a lawyer who aids such organizations by appearing on the program would be acting in violation of Canon $47 .{ }^{25}$

In Formal Opinion 298, issued in 1961, the Committee reaffirmed the position it had taken in 1938, noting that the emergence of television

that the law in one state may be different from the law in another state. The air waves are no respecters of state lines." Id.

Occasional bar opinions during this period suggest that the problem of legal advice on the air had not disappeared completely in the 1930s. See, e.g., ABA Comm. on Professional Ethics and Grievances, Informal Op. 228 (1941), reprinted in ABA Opinions, supra note 183, at 524 ("A lawyer may not answer on a radio program specific questions with reference to the law; for a lawyer thus to answer general questions is fairly certain to involve him, sooner or later, in the violation of Canon 40 and Canon 27."); Ass'n of the Bar of the City of N.Y. Comm. on Prof'l Ethics, Op. 648 (1943) (indicating that a lawyer may not go on air with an inventor to give a legal opinion as to how to protect her rights in an invention because the lawyer "would be broadcasting legal information and advice regarding the individual rights of a person in a specific case"); id. Op. 716 (1948) (stating that lawyers participating in a television talk show about well-known cases must exercise care that "the discussion of such cases cannot be interpreted as advice on individual rights to any parties who may have similar problems not yet adjudicated"); id. Op. 805 (1955) (cautioning that an immigration lawyer appearing on air periodically to give legal information must not advise about individual legal rights); see also N.J. Sup. Ct. Comm. on Unauthorized Prac., Op. 4 (1971) (affirming that giving legal advice on the radio and in newspapers to individuals is the practice of law because " $[\mathrm{t}]$ he vice . . is that individuals submit their personal problems, and they are specifically answered by the columnist or the commentator" (citing Green v. Huntington Nat'l Bank, 209 N.E.2d 228 (Ohio Ct. App. 1964))).

254. On May 8, 1938, the Committee issued Formal Opinion 179, approving local bar sponsorship of a radio broadcast of a sketch depicting the "unfortunate consequences" of failing to get a lawyer to draft a will. ABA Comm. on Professional Ethics and Grievances, Formal Op. 179 (1938), reprinted in ABA OPINIONS, supra note 183, at 449. The opinion characterized this kind of broadcast as educational and thus distinguishable from attempts to solicit new clients, which would "injure the public and degrade the profession." Id.

255. ABA Comm. on Professional Ethics, Informal Op. 528 (1962). 
had raised the issue again. The opinion asserted that judges might not appear in simulated judicial proceedings, but permitted lawyers to appear as actors or performers, as long as the program "conform[ed] to the proper standards of the Bench and Bar in their participation in judicial or other proceedings. "256

The modern era of regulating attorney speech began in 1977, with the Supreme Court's landmark decision in Bates v. State Bar. ${ }^{257}$ In Bates, the Court held that blanket restrictions on lawyer advertising were unconstitutional. ${ }^{258}$ That decision required the bar to rethink the traditional prohibitions against self-promotion underlying many ethics opinions of the prior forty years. Nevertheless, the approach of subsequent bar opinions addressing the issue of lawyer participation in radio and television advice programs has been strikingly similar to that of the early opinions. General educational presentations have been approved, ${ }^{259}$ but a number of opinions have reiterated cautions against furnishing specific legal advice to individuals over the air. ${ }^{260}$

256. ABA Comm. on Professional Ethics, Formal Op. 298 (1961), reprinted in ABA OpINIONS, supra note 183, at 655. See also ABA Comm. on Professional Ethics, Informal Op. 230g (1961) (distinguishing Meet the Press as not implicated in Formal Op. 298), Informal Op. 1136 (1969) (stating that a recurring program on public television addressing matters of public interest was permissible, as long as the program was "conducted with dignity, no legal advice was given, and the entire operation seemed interesting and informative").

257. 433 U.S. 350 (1977).

258. See id. at 383.

259. See N.J. Sup. Ct. Advisory Comm. on Prof'l Ethics, Op. 480 (1981) (quoting the Standing Committee on Association Communications and Division of Communications of the American Bar Association):

The legal profession is not an island unto itself. It is in the mainstream of American life. It must be responsive to the human needs of society. The law is neither rigid nor detached from those whom it serves, and neither can members of the legal profession function apart from society. They must reach out, become more visible as part of the social fabric, and help the citizenry to realize more fully that the law serves the people, not the people the law.

260. For example, Ohio Ethics Opinion 94-13 noted that radio may be an appropriate method for educating the public generally about legal issues, but cautioned that if the format permits listeners to ask questions, "a lawyer participating in this type of radio show must be extremely careful not to impart individual advice." Ohio Sup. Ct. Bd. of Comm'rs on Grievances \& Discipline, Op. 94-13 (1994). The opinion also warns that lawyers should be cautious about learning secrets and confidences on the air. The Ohio opinion recommended a disclaimer, suggesting that "it may be prudent for a lawyer to advise a radio audience that discussion in regard to questions will be general and not intended as individual advice for specific problems." Id.; accord Ala. St. Bar, Op. 349 (1980) (stating that a lawyer may participate in radio interview as long as the lawyer refrains from giving general solutions to individual problems); Conn. Bar Ass'n Comm. on Prof'l Ethics, Op. 89-19 (1971) (stating that a 90-second radio spot must "not leave the impression that the [lawyer is] giving general advice applicable to all individuals with similar problems"); Fla. St. Bar Ass'n Comm. on Prof'l Ethics, Op. 71-35 
Just as their counterparts in the 1930s, these bar opinions express the concern that a lawyer giving individual legal advice on the radio will have insufficient facts to give a full response, ${ }^{261}$ that a broadcast exchange between a lawyer and questioner could raise concerns of confidentiality, ${ }^{262}$ and that other listeners might erroneously rely on the advice given. ${ }^{263}$ Moreover, even though a number of bar opinions have recommended the use of disclaimers, ${ }^{264}$ no opinion has taken the

(1971) (asserting that a lawyer may appear on a radio show, but must "not seek to solve specific problems"); Ky. Bar Ass'n Ethics Comm., Op. E-270 (1983) (opining that a lawyer "should not give personal legal advice to individuals who may call in to the program"); Miss. St. Bar Ass'n Ethics Comm., Op. 74 (1982) (stating that a lawyer may appear on a public service newscast as long as the lawyer "refrains from giving, or appearing to give advice, to particular persons about their individual rights"); Ass'n of the Bar of the City of N.Y. Comm. on Prof'l \& Judicial Ethics, Op. 80-8 (1980) (asserting that a "lawyer may not give individual legal advice in response to specific questions posed by individual callers"); S.C. Bar Ethics Advisory Comm., Op. 86-4 (undated) (cautioning that there is a danger from the "implication which arises that the broadcast attorney is an expert or specialist in the field in which he purports to offer advice"). See generally Rogers, supra note 11, at 67-72 (discussing bar opinions). Modern television programs such as Judge Judy are distinguishable because they purport to mediate disputes rather than proffer legal advice.

261. See N.J. Sup. Ct. Advisory Comm. on Prof'l Ethics, Op. 480 (1981) (recommending that programs publicize disclaimers informing the public that the "general answers given are not a complete analysis of the legal problems"); Ass'n of the Bar of the City of N.Y. Comm. on Prof'l \& Judicial Ethics, Op. 80-8 (1980) (noting that the time constraints of a radio program would "preclude[] the lawyer from probing the caller to elicit the factual information she needs").

262. See, e.g., Ass'n of the Bar of the City of N.Y. Comm. on Prof'l \& Judicial Ethics, Op. 80-8 (1980) (observing that a radio program is not conducive to confidential communications); Ohio Sup. Ct. Bd. of Comm'rs on Grievances \& Discipline, Op. 94-13 (1994) (“[C]onfidences and secrets should not be divulged over the radio.").

263. See Conn. Bar Ass'n Comm. on Prof'l Ethics, Op. 89-19 (1989) (advising that a radio broadcast should not leave the impression that a lawyer was giving advice applicable to all individuals with similar problems); Ass'n of the Bar of the City of N.Y. Comm. on Prof'l \& Judicial Ethics, Op. 80-8 (1980) ("[M] embers of the public who have problems that appear similar to the question posed may be misled into accepting the publicly disseminated question and answer as applicable to their own problems.").

264. See, e.g., N.J. Sup. Ct. Advisory Comm. on Prof'l Ethics, Op. 480 (1981) (cautioning that a lawyer's answering anonymous questions on the radio raises the risk of erroneous response from lack of adequate information and that there should therefore "be a disclaimer advising the inquirer to the effect that on the basis of the question presented, the general answer appears to be thus and so that for the inquirer's protection it is recommended that they seek competent legal advice"); Ohio Sup. Ct. Bd. of Comm'rs on Grievances \& Discipline, Op. 9413 (1994):

As with legal seminars, it may be prudent for a lawyer to advise a radio audience that discussion in regard to questions will be general and not intended as individual advice for specific problems. In addition, it may be helpful for the attorney to remind the radio audience not to divulge confidences.

A disclaimer recommended by a Connecticut bar opinion reads: 
position that the disclaimer will relieve a lawyer of liability for individual advice given on the air. ${ }^{265}$ Indeed, one New Hampshire bar opinion warns attorneys participating in a radio call-in program to consider "the possibility that a relationship may be established with the callers that will implicate the rules concerning the confidentiality of information and conflicts of interest." 266

The modern bar opinion most critical of radio call-in shows is Iowa Opinion 93-8. ${ }^{267}$ It expressly disapproves of a law firm-sponsored radio call-in show in which callers, having been pre-screened for conflicts of interest with firm members, would have their questions either answered on the air or referred to the bar association. This opinion flatly asserts that "[t]he public broadcasting of an interview between a client and a lawyer would be in violation of the lawyer's responsibility to protect the confidences of clients." 268 It further notes: "Lawyers traditionally provide legal advice to their established clients. However, it is difficult to see how such a relationship can arise out of a simple contact by telephone, without personal confrontation and without means to identify or otherwise personally to relate

This program is being brought to you as a public service of the Connecticut Bar Association. The purpose of this program is to provide the public with general legal information and an insight into the judicial process. It is not designed to provide answers to specific legal programs [sic] or to disseminate legal advice on pending cases of controversies.

Conn. Bar Ass'n Comm. on Prof'l Ethics, Op. 89-4 (1989). The frequency of announcing the disclaimer is important because listeners tune in at different times and may not hear a disclaimer read only at the beginning. See N.H. Bar Ass'n Ethics Comm., Op. 1994/95-3 (1995).

265. In a New Hampshire opinion, a lawyer's call-in program featured the following disclaimer:

Every problem is unique and the producers of this program and the New Hampshire Bar Association want everyone listening to understand that it is very important to consult with your own attorney prior to applying the advice heard on this or any other program to their own situation as small changes in the facts can completely change the legal result. Further, the attorneys on this program want to be sure that all listeners understand that only their own lawyer can take the time to fully understand their individual problems and properly advise them of the correct legal action.

N.H. Bar Ass'n Ethics Comm., Op. 1994/95-3 (1995). Nevertheless, the opinion went on to caution: "[I]n addition to broadcasting the proposed disclaimer, the program attorneys are cautioned to avoid providing specific answers to any caller, and each answer should explain that additional facts may change the legal advice applicable to a particular situation . . . " Id.; $c f$. Ass'n of the Bar of the City of N.Y. Comm. on Prof'l \& Judicial Ethics, Op. 80-8 (1980) (recommending that lawyers not give individual advice over the radio because when "the lawyer's relationship with the inquirer is fleeting and impersonal, the lawyer may have a diminished sense of professional responsibility to the inquirer").

266. N.H. Bar Ass'n Ethics Comm., Op. 1994/95-3 (1995).

267. See Iowa Sup. Ct. Bd. of Prof'l Ethics \& Conduct, Op. 93-8 (1993).

268. Id. 
to the inquirer and to determine all the necessary information to render an informed opinion." ${ }^{269}$ The Iowa opinion reflects how deeply rooted the hostility toward nontraditional advice-giving may be within the bar. ${ }^{270}$

To what extent do cyberspace and on-air advice-giving parallel one another? On the one hand, legal advice given in an open forum such as a chat room or website resembles advice given over the radio in that it is open to any member of the public and thus lacks confidentiality. But this is not true with respect to individualized exchanges of e-mail between a questioner and an individual lawyer. On the other hand, in the medium of cyberspace the questioner may have a greater opportunity to provide information to the lawyer than he would have in a radio broadcast. Moreover, unless the exchange occurs in real time, the lawyer has ample time to consider her answer to the question and need not provide the "off-the-cuff" advice that the bar so often decries.

\section{B. Giving Legal Advice in Writing}

1. Giving Legal Advice in Newspaper Columns. Because communication in cyberspace today primarily consists of writing, another analog of online advice is the newspaper advice column. Concerns about regulating legal advice in newspaper columns emerged in the 1920s and have been the source of published bar opinions ever since. As in the case of radio and television broadcasts, bar regulators have focused largely on ensuring that lawyers give no specific legal advice in these columns.

When the ABA substantially revised and supplemented its 1908 Canons of Professional Ethics in $1928,{ }^{271}$ it added a section specifically addressing the issue of newspaper advice columns. Canon 40, "Newspapers," simply provided: "A lawyer may with propriety write articles for publication in which he gives information upon the law; but

269. Id.

270. The opinion certainly overstates its case in suggesting that lawyers must meet face-toface with clients in order to serve them professionally, as many lawyers have no doubt provided legal services to clients whom they have never met in person.

271. Supplemental Canons to the original Canons were proposed for adoption in 1928. See J. Purdon Wright, Important Supplemental Canons of Ethics Proposed, 14 A.B.A. J. 292, 292 (1928). They were adopted in July 1928. See Striking and Successful Celebration of Association's Semi-Centennial, 14 A.B.A. J. 447, 479 (1928). 
he should not accept employment from such publications to advise inquirers in respect to their individual rights." ${ }^{272}$ Canon 35, another new section, also provided some basis for limiting legal advice columns. Titled "Intermediaries," it stated:

The professional services of a lawyer should not be controlled or exploited by any lay agency, personal or corporate, which intervenes between client and lawyer. A lawyer's responsibilities and qualifications are individual. He should avoid all relations which direct the performance of his duties by or in the interest of such intermediary. A lawyer's relation to his client should be personal, and the responsibility should be direct to his client. ${ }^{273}$

Although the record is murky, the issue of newspaper columns apparently caused enough concern to prompt the ABA's Committee on Professional Responsibility to dedicate a number of formal opinions to the topic in the 1930s and 1940s.

The early ABA opinions set the tone for what would be the prevailing standards for regulating legal advice in newspapers. ${ }^{274}$ The first formal opinion to address the issue of publishing legal advice, issued in 1933, stated:

A lawyer is not justified in giving an opinion without an opportunity to ask the client for information as to the concrete facts in the client's case, and without an opportunity to see the instruments or documents and to ascertain the dates and other facts, which the client has not given or may not deem material. Nor can the client be safe in acting on generalizations. And, moreover, other member banks having problems similar to the question answered, may be misled into accepting the published question and answer as applicable to their own problems. ${ }^{275}$

272. Model Code of Professional Responsibility Canon 40 (1928).

273. Professional Ethics Committee Rules of Procedure, 32 A.B.A. J. 302, 303 (1946).

274. The first Formal Opinion to construe Canon 40 was Opinion 92, issued on May 2, 1933, which endorsed the publication of articles on general legal subjects, assuming that they would be "dignified and instructive treatment[s] of the law, its history, philosophy, and interpretation." ABA Comm. on Professional Ethics and Grievances, Formal Op. 92 (1933), reprinted in ABA OpINIONS, supra note 183, at 340.

275. ABA Comm. on Professional Ethics and Grievances, Formal Op. 98 (1933), reprinted in ABA OpINIONS, supra note 183, at 347. Publishing this opinion on August 29, 1933, the Committee responded to a query by attorneys representing a state bankers' association that answered written questions from member banks in a series of written "legal bulletins." $I d$. The Committee asserted that this type of advice controverted Canon 35, because it could "easily be used as a means of advertising the professional services of the lawyers, as well as exploiting 
By 1945, the committee had flatly condemned newspaper advice columns. In Formal Opinion 270, the committee addressed a column that was to publish answers to questions of interest to the general public. The prospective author, an attorney, had said that the column would be "brief, concise, correct, and if there [were] the slightest doubt about the correctness of the particular answers, then the question and answer [would] not be printed in the column." ${ }^{276}$ The attorney also proposed to publish a disclaimer in which "the reader [would] be cautioned not to rely on the answer in the column as legal advice, but to consult his attorney," and he promised to issue his answers under an assumed name. ${ }^{277}$ Despite these extensive precautions, the committee asserted that this column would violate both Canon 35 and Canon 40. Opinion 270 explained:

The column will be in essence one in which the lawyer undertakes to give advice for the benefit of inquiries in respect of their individual rights, which Canon 40 forbids. Finally, it does not meet the requirement of Canon 35 that the relations of a lawyer with those to

\begin{abstract}
their services for the profit of a lay agency." Id. The opinion contrasted this activity with that approved in Opinion 92, "where concrete questions are not submitted by a party seeking legal advice relating to his own situation." Id. A similar issue arose again in Formal Opinion 162, issued on August 22, 1936, where a trade magazine offered its members a lawyer-written advice column concerning legal issues common to the journal's subscribers. See ABA Comm. on Professional Ethics and Grievances, Formal Op. 162 (1936), reprinted in ABA OPINIONS, supra note 183, at 432. The Committee approved the publication of articles of general interest, but said that "it would be unethical and contrary to the precepts of the Canons for the attorney to allow his name to be carried in the magazine or other publication in the manner indicated in the foregoing statement, as a free legal adviser for the subscribers to the publication." Id. The Committee addressed this issue more fully in Opinion 273, issued on October 25, 1946, in permitting a general counsel of a trade association to issue opinions on matters of general interest that would be circulated through bulletins to the association's members. See ABA Comm. on Professional Ethics and Grievances, Formal Op. 273 (1946), reprinted in ABA OPINIONS, supra note 183 , at 605 . The Committee noted that the republication of these bulletins had recently been held to be unauthorized practice by the ABA's Committee on Unauthorized Practice of Law. See id. Nevertheless, the Committee noted that issuing general opinions was not necessarily improper:
\end{abstract}

In any case where a member might well apply the advice given in the opinion to his individual affairs, the lawyer rendering the opinion should specifically state that this opinion should not be relied on by any member as a basis for handling his individual affairs, but that in every case he should consult his counsel. In the publication of the opinion the association should make a similar statement.

Id.

276. Professional Ethics Committee Rules of Procedure, supra note 273, at 303.

277. Id. 
whom he gives legal advice should be direct and personal and that this service must not be exploited by an intervening lay agency. ${ }^{278}$

In order to avoid the scope of Canon 40, Opinion 270 noted, any advice given in articles had to be of a "general nature on legal subjects." 279 Opinion 270 remained the leading word on newspaper columns for nearly twenty-five years. ${ }^{280}$

Although the concern about newspaper advice columns lingered into the 1960s, the ABA's attitude toward newspaper advice columns changed in 1969 when the Model Code of Professional Responsibility superseded the Canons of Professional Ethics. The new Model Code specifically addressed the question of publications by lawyers in Disciplinary Rule 2-104(A)(4). ${ }^{281}$ Titled "Suggestion of Need of Legal Services," the rule precluded lawyers from accepting employment resulting from "in-person unsolicited advice to a lay person," but appended a carefully worded exception: "Without affecting his right to accept employment, a lawyer may speak publicly or write for publica-

278. ABA Comm. on Professional Ethics and Grievances, Formal Op. 270 (1945), reprinted in ABA OPINIONS, supra note 183, at 598.

279. See id. Henry Drinker, one of the leading figures in the development of legal ethics, was a member of the committee that issued Opinion 270. In his influential treatise entitled Modern Legal Ethics, he furnished this rationale for such close scrutiny of newspaper advice columns:

It is believed that Canon 40 was designed primarily to sanction articles in law magazines or occasional articles in other publications and that it would be difficult if not impossible to conceive of a daily, weekly, or monthly column in a newspaper or magazine devoted to the discussion of legal matters which would not, sooner or later, violate Canon 40 and also Canons 27, 35, and 47. What the readers of such columns want is not a general discussion such as they can find in a law book or in an article in a law magazine, but something practical which they can apply to their own personal experience. Laymen usually are unable to formulate questions clearly to such a column and a lawyer answering such is apt to follow what he thinks his readers will want to hear about and to answer the personal problem which he sees behind their questions. This is what the publications will ultimately see that they get.

HeNRY S. DRINKER, MODERn LEgAl ETHICs 264 (1953). Drinker also asserted that Canon 40 would be violated by "[t]he giving by [the lawyer] of legal advice to persons with whom he has not the personal contact and background required between lawyer and client to make his advice reliable" and by "[e]nabling the lay publisher, sponsor, or broadcaster to give legal advice, constituting the unauthorized practice of law." Id. at 263.

280. Opinion 270 was followed in at least three informal ABA opinions. See ABA Comm. on Professional Ethics, Informal Op. 463 (1961) (asserting that a bar association may publish a news column of a general nature on legal subjects); Informal Op. 538 (1962) (stating that contributing an article treating a practical question of law will not violate the ABA canons); Informal Op. 840 (1965) (describing rules meant to guide lawyers participating in legal seminars).

281. Model Code of Professional ResPonsibility DR 2-104(a)(4) (1980). 
tion on legal topics so long as he does not emphasize his own professional experience or reputation and does not undertake to give individual advice." 282 Accompanying Ethical Consideration 2-2 explained the purpose of this rule:

A lawyer who writes or speaks for the purpose of educating members of the public to recognize their legal problems should carefully refrain from giving or appearing to give a general solution applicable to all apparently similar individual problems, since slight changes in fact situations may require a material variance in the applicable advice; otherwise, the public may be misled and misadvised. Talks and writings by lawyers for laypersons should caution them not to attempt to solve individual problems upon the basis of the information contained therein. ${ }^{283}$

Ethical Consideration 2-2 acknowledged, however, that a public purpose could be achieved by lawyers attempting to educate laypeople about their legal rights. ${ }^{284}$ For whatever reason, very little attention has been focused on newspaper advice columns since the advent of the Model Code of Professional Responsibility. ${ }^{285}$ Indeed, the Model Rules of Professional Conduct, which largely have supplanted the Model Code, make no specific mention of newspaper advice columns. $^{286}$

In recent years, state bars have issued a handful of opinions on newspaper advice columns, continuing the traditional prohibition

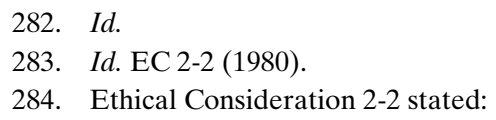

The legal profession should assist lay-persons to recognize legal problems because such problems may not be self-revealing and often are not timely noticed. Therefore, lawyers should encourage and participate in educational and public relations programs concerning our legal system with particular reference to legal problems that frequently arise. Preparation of advertisements and professional articles for lay publications and participation in seminars, lectures, and civic programs should be motivated by a desire to educate the public to an awareness of legal needs and to provide information relevant to the selection of the most appropriate counsel rather than to obtain publicity for particular lawyers.

Id.

285. The most recent application of the Model Code in this area is Informal Opinion 1464, which summarizes the past opinions. See ABA Comm. on Ethics and Professional Responsibility, Informal Op. 1464 (1980).

286. This may suggest that much, if not all, of the concern with newspaper columns was generated by the bar's ban on advertising and other self-promotion that was held unconstitutional by the Supreme Court in Bates. See supra notes 257-258 and accompanying text. [xref] 
against giving specific legal advice. ${ }^{287}$ The general response in most bar opinions has been to endorse efforts to educate the public, but also to express strong reservations about the lawyer answering legal questions.

The similarities between newspaper columns and online legal advice readily emerge when looking at a typical bar opinion from the 1970s, Florida Opinion No. 70-30. ${ }^{288}$ In that opinion, the Florida Committee on Professional Ethics considered a few sample questions that might be sent to a lawyer by inquiring laypersons. One sample question and answer provided by the lawyer read:

Q. I pay my rent on the first day of each month in advance. I have no lease. Must the landlord give me notice if he wants me to move? Must I give the landlord the same notice if I want to move?

A. Yes to both questions. At least fifteen days advance notice is required if a landlord wants the tenant to move at the end of the month. Similarly, a tenant is required to give the same notice if he intends to move at the end of the month. ${ }^{289}$

The Florida committee disapproved of this practice, relying on ABA Opinion 270 to note that "legal columns must be limited to answering general questions." ${ }^{290}$ As in the opinions on radio and television ad-

287. See, e.g., Ala. St. Bar, Op. 86-27 (1986) (allowing an article to be written providing only general legal information); Fla. St. Bar Ass'n Comm. on Prof'l Ethics, Op. 75-16 (1975) (allowing a lawyer to write an article based on general information only); id. Op. 60-28 (1961) (forbidding a lawyer to write an article answering legal questions and noting that local bar associations already maintain legal aid services that provide legal assistance without cost); Miss. St. Bar Ass'n Ethics Comm., Op. 109 (1985) (allowing a lawyer to write an article based on general information); N.J. Sup. Ct. Comm. on Unauthorized Prac., Op. 4 (1971) (prohibiting a lawyer from writing an article giving individualized legal advice); R.I. Sup. Ct. Ethics Advisory Panel, Op. 93-9 (1993) (allowing articles of general legal significance to be written by lawyers); Sup. Ct. of Tex. Prof'l Ethics Comm., Op. 425 (1985) (same); Va. St. Bar Standing Comm. on Legal Ethics, Op. 410 (1983) (same).

288. See Fla. St. Bar Ass'n Comm. on Prof'l Ethics, Op. 70-30 (1970).

289. Id.

290. Id. The Committee on Professional Ethics was concerned that the "format of the column and questions being answered [did] not comport with the limitations properly indicated by the Code of Professional Responsibility, EC 2-5 and DR 2-104." Id. The Committee found precedent for its decision in ABA Formal Opinion 270, which held "that an attorney may not answer individual inquiries for legal advice through a newspaper column." Id.; see also N.J. Sup. Ct. Comm. on Unauthorized Prac., Op. 4 (1971) (stating that "[t]he vice of the posited question is that individuals submit their personal problems, and they are specifically answered by the columnist or the commentator"). The only bar opinion that has approved the giving of specific legal advice is Oregon Opinion 1991-3, issued in July 1991. See Or. St. Bar Ass'n Legal 
vice, the bar opinions addressing newspaper advice columns have urged the use of disclaimers to impress upon readers that they must not rely on the information provided in the column. ${ }^{291}$

The treatment of newspaper advice columns closely mirrors that of radio and television advice programs, although there are substantial differences between the two types of advice-giving. In newspaper columns, there is no direct communication between questioner and answerer, as there generally is on radio and television programs. A lawyer writing a newspaper column has more time to reflect upon the answer, including time to check for conflicts and to ensure a competent reply. On the other hand, the question and answer in these settings are given in public, without confidentiality. Newspaper advice columns are somewhat akin to Dear Esquire and other such websites, except that on many such sites there is little, if any, editorial control over the content posted by either questioners or answerers. The level of detail in Internet queries far exceeds what one would expect to see in a newspaper column, and often the reply is far more specific and pointed. Again, however, we can see that the bar's prohibition on giving specific advice has been consistent, regardless of the medium used.

Ethics Comm., Op. 1991-3 (1991). When considering the inquiry, the Oregon Bar Association prohibited the lawyer from making only "false or misleading communications." Id.

291. An Alabama bar committee addressed the use of disclaimers in two separate opinions. One opinion recommended but did not require a disclaimer at the end of a lawyer's newspaper column. See Ala. St. Bar, Op. 86-27 (1986). The other stated that a disclaimer would be required if a newspaper column contained "a statement or claim regarding the services offered by the lawyer." Ala. St. Bar, Op. 87-141 (1987). Additionally, Alabama Opinion 82-577 cautioned against the "inherent dangers" of newspaper advice columns:

1) giving or appearing to give a general solution applicable to all apparently similar individual problems, 2) attempting to solve individual problems of specific lay readers, and 3) accepting private employment which can be traced to advice [given] to a lay reader in an article in connection with which [the lawyer's] professional experience or reputation was emphasized.

Ala. St. Bar, Op. 82-577 (1982). Bar opinions often endorse the use of disclaimers to advise the public about the general nature of the information provided and the danger of relying on the column to solve their own legal problems. See, e.g., Fla. St. Bar Ass'n Comm. on Prof'l Ethics, Op. 70-30 (1970) (stating that an attorney's legal column in the newspaper should be limited to general answers); Sup. Ct. of Tex. Prof'l Ethics Comm., Op. 425 (1985):

EC 2-5 cautions that a lawyer in educating the public in the recognition of legal problems should be careful to avoid giving the impression that a general solution is applicable to all similar problems, since the different fact situations obviously vary the proper advice. Therefore, writings by lawyers for laymen should caution them not to attempt to solve individual problems upon the basis of the information given. 
2. Giving Legal Advice in Books. The question of lawyers' giving legal advice in books and treatises has arisen far less frequently than advice-giving in other media, but there have been a few attempts to regulate conduct in this area. ${ }^{292}$ First, in 1941, the ABA's Standing Committee on Unauthorized Practice of Law, together with the Committee of Publishers and Associations on Bar Cooperation, adopted a Declaration of Principles on the publication of law books. The Declaration stated: "It is the duty of such organizations studiously to avoid granting requests for advice or the performance of other services which would constitute the practice of law and not hesitate to suggest, in reply to such requests, that the inquirers' own counsel be consulted in such matters." ${ }^{293}$ The Declaration further agreed that law books published after August 1, 1941, would carry a disclaimer with respect to the furnishing of legal advice. ${ }^{294}$ Whether this agreement had any effect is unclear, but by the 1970s cooperative efforts like this one had raised substantial antitrust concerns and generally had been rescinded. ${ }^{295}$ Second, many state bars, worried about the unauthorized practice of law, attempted to prevent the publication of "self-help" legal books. ${ }^{296}$ The leading case of New York County Lawyers' Ass'n v. Dacey ${ }^{297}$ took the position that publication of How to Avoid Probate by a lawyer did not constitute

292. Far more energy has been devoted to controlling the ability of laypeople to publish legal advice in books. See WOLFRAM, supra note 98, § 15.1.2, at 828 (stating that "[t]he bar's largely successful campaign against unauthorized practice has left a large field free from nonlawyer competition").

293. Declaration of Principles, 7 UnAuthorized PraC. News 37, 38 (1941).

294. Id. ("It is sold with the understanding that the publisher is not engaged in rendering legal, accounting, or other professional service"). The 1947 ABA Journal, reporting an accord reached in December 1946 to implement these principles, explained: "A principal objective of the association was to lessen and forestall the sale of such books and services, and their use by non-lawyers, on the basis of express or implied representations that they obviated the need for obtaining definitive advice from lawyers in particular cases arising." Representations As to Law Books: Important Principles Agreed to by Publishers, 33 A.B.A. J. 28, 28 (1947).

295. See Rhode, supra note 180 , at 10 n.36.

296. See, e.g., Dacey v. Florida Bar, 427 F.2d 1292, 1294 (5th Cir. 1970) (describing an action for unauthorized practice brought by the Florida Bar against the author of book on avoiding probate); Grievance Comm. v. Dacey, 222 A.2d 339, 352 (Conn. 1969) (holding that an estate planner engaged in the unauthorized practice of law by distributing booklets on trusts and then preparing wills and trusts for clients); Oregon State Bar v. Gilchrist, 538 P.2d 913, 913 (Or. 1975) (holding that the publication of a do-it-yourself divorce manual was not the practice of law).

297. 21 N.Y.2d 694 (1967). 
the practice of law because there was neither personal contact nor personal advice given on a specific problem. ${ }^{298}$

The distinction drawn by Dacey is logical: books do not respond directly to questions posed by laypeople, and thus they do not create the same concerns about personalized legal advice as radio talk shows and newspaper columns. ${ }^{299}$ There simply is no interaction between the author and the anonymous individual with a legal problem who purchases the book; the author does not purport to bring legal expertise to bear on a set of specific facts. ${ }^{300}$ The general distinction between general information and specific legal advice can easily be observed in this context. ${ }^{301}$ The closest online analogy to publishing legal advice in books would be the posting of general newsletters, ar-

298. See id. at 695; see also Gilchrist, 538 P.2d at 917 (stating that a book "offer[s] general advice on common problems, and does not purport to give personal advice on a specific problem peculiar to a designated or readily identified person"). There is a minority view that treats books as the equivalent of legal advice, and some jurisdictions have suggested that "comprehensive and specific" advice in a divorce kit "parallel[ed] much of what an attorney would customarily advise his clients who seek dissolution of marriage." Florida Bar v. Stupica, 300 So. 2d 683 (Fla. 1974), quoted in Andrew S. Morrison, Is Divorce Mediation the Practice of Law? A Matter of Perspective, 75 CAL. L. REV 1093, 1105 (1995).

299. According to one ethics opinion, the principal concern for such books is careful avoidance of Rule 8.4 misconduct, because publishing "grossly erroneous or misleading materials" could constitute a violation of 8.4(c) or 8.4(d). Utah St. Bar Ethics Advisory Opinion Comm., Op. 95-01 (1995) (noting that "[i]n the mere publication of forms or text, there is no personal contact or relationship to any particular individual, nor is personal advice given on a specific problem peculiar to a designated or readily identified person"). Nevertheless, the Philadelphia Bar Association took the position that writing a book as an attorney "might be considered practicing law, particularly if individuals are going to rely on it in making decisions that may affect their legal rights and liabilities." Phila. Bar Ass'n Prof'l Guidance Comm., Op. 93-16 (1993). The Committee further cautioned that the information in the book should be accurate and up-to-date when published. See id. For a collection of cases on the question of when the sale of books constitutes the unauthorized practice of law, see Patricia J. Lamkin, Annotation, Sale of Books or Forms Designed to Enable Laymen to Achieve Legal Results Without Assistance of Attorney as Unauthorized Practice, 71 A.L.R.3d 1000 (1976).

300. But see Fadia v. Unauthorized Practice of Law Comm., 830 S.W.2d 162, 162 (Tex. App. 1992) (finding no difference between personal legal advice and legal advice published in a book).

301. See State Bar of Mich. v. Cramer, 249 N.W.2d 1, 9 (Mich. 1976) (stating that the advertisement and distribution to the general public of no-fault divorce forms coupled with general textual instructions is not the unauthorized practice of law); In re Thompson, 574 S.W.2d 365, 369 (Mo. 1978) (holding that the advertisement and sale of divorce kits does not constitute the unauthorized practice of law unless personal advice as to legal remedies is given); $c f$. ABA Comm. on Professional Ethics, Informal Op. 1195 (1971) (stating that the publication of a book about draft deferments does not constitute the practice of law, but should still observe the "spirit" of Ethical Consideration 2-5). 
ticles, or other legal writings on a lawyer's website, an activity that is unlikely to be viewed as creating an attorney-client relationship. ${ }^{302}$

\section{Giving Legal Advice in Seminars}

More analogous to the provision of specific legal advice online are seminars, which recently have received attention from the bar. Because of their inherent promotional nature, seminars generally were prohibited prior to the adoption of Ethical Considerations 2-2 and 2-5 of the Model Code. Those sections stressed the important educational function seminars could serve. ${ }^{303}$ By the early 1980s, the newly adopted Model Rules had eliminated any reference to seminars, and, in the last fifteen years, the use of seminars by lawyers as a marketing tool has increased substantially. ${ }^{304}$ At the same time, state bars have focused increasingly on potential ethical pitfalls of seminars, as evidenced by a large number of opinions in recent years. ${ }^{305}$

302. The current controversy over the investigation of Nolo Press by the Texas State Bar for unauthorized practice of law indicates that the battle over giving legal advice in "do-ityourself" books continues to rage. See Fried, supra note 51, at A4; Nolo Press, Your Right to Use Self-Help Law Books and Software, (visited Sept. 20, 1999) $<$ http://www.nolopress.com/texas/rights.html> (on file with the Duke Law Journal). Nolo's legal self-help software is also under investigation. See John Council, Self-Help Legal Software Judged Unauthorized Practice in Texas, Legal InTELligencer, Feb. 2, 1999, at 4.

303. See Model Code of Professional Responsibility EC 2-2 (1980) (stating that "[t]he legal profession should assist laypersons to recognize legal problems because such problems may not be self revealing"); id. EC 2.5 ("A lawyer who writes or speaks for the purpose of educating members of the public to recognize legal problems should carefully refrain from giving ... a general solution applicable to all apparently similar individual problems.").

304. See generally Frederick C. Moss, The Ethics of Law Practice Marketing, 61 NOTRE Dame L. ReV. 601, 661 (1986); Nina Keilin, Note, Client Outreach 101: Solicitation of Elderly Clients by Seminar Under the Model Rules of Professional Conduct, 62 FordHAM L. REV. 1547, 1561 (1994).

305. See, e.g., Ala. St. Bar, Op. 86-115 (1986) (advising that lawyers can speak at legal seminars so long as they do not profess to give individual advice and do not attempt to solicit clients); Fla. St. Bar Ass'n Comm. on Prof'l Ethics, Op. 75-36 (1977) (suggesting that lawyers can teach seminars so long as they do not seek to give individual advice at such seminars); Ind. St. Bar Ass'n Legal Ethics Comm., Op. 10 (1986) (advising that lawyers may use seminars to provide information to the public about the availability of legal services "so long as such information does not purport to provide general solutions to individual problems"); Mass. Bar Ass'n Comm. on Prof'l Ethics, Op. 83-4 (1983) (suggesting that seminars are ethically acceptable, but that lawyers must refrain from soliciting clients while conducting them); N.J. Sup. Ct. Advisory Comm. on Prof'l Ethics, Op. 548 (1984) (affirming the ethical propriety of seminars so long as they have an educational purpose and are not merely a forum for soliciting clients); Sup. Ct. of Tex. Prof'l Ethics Comm., Op. 489 (1992) (suggesting that seminars are ethically acceptable so long as they are not designed primarily for publicity or profit and so long as lawyers participating in such seminars do not answer laypersons' questions regarding specific problems). Like 
Among the ethical issues to have arisen is the question of giving specific legal advice to participants in seminars, either during a questionand-answer period or in individual conversations. Once again, bar opinions have drawn a distinction between giving general legal information and tailoring legal advice to the specific facts put forth by the inquirer. These opinions usually have allowed lawyers to answer requests for general legal information. ${ }^{306}$ On the other hand, a number of bar opinions have emphatically warned lawyers not to answer specific legal questions during seminars. ${ }^{307} \mathrm{~A}$ "seminar must be to inform rather than to give legal advice." ${ }^{308}$

opinions are Ala. St. Bar, Op. 87-119 (1987); id. Op. 86-49 (1986); State Bar of Ariz. Comm. on Rules of Prof'l Conduct; id. Op. 92-10 (1992); id. Op. 88-7 (1988); id. Op. 87-12 (1987); Cincinnati Bar Ass'n Ethics \& Prof'l Responsibility Comm., Op. 94-95-03 (undated); Conn. Bar Ass'n Comm. on Prof'l Ethics, Op. 94-3 (1994); Haw. Sup. Ct. Disciplinary Bd., Op. 78516 (1978); Ill. St. Bar Ass'n, Op. 94-4 (1994); id. Op. 763 (1982); Iowa Sup. Ct. Bd. of Prof'l Ethics \& Conduct, Op. 91-16 (1991); id. Op. 89-41 (1990); Md. St. Bar Ass'n Comm. on Ethics, Op. 88-33 (1988); id. Op. 81-36 (1981); Mass. Bar Ass'n Comm. on Prof'l Ethics, Op. 86-3 (1986); State Bar of Mich. Standing Comm. on Prof'l \& Judicial Ethics, Op. RI-99 (1991); id. Op. RI-81 (1991); Miss. St. Bar Ass'n Ethics Comm., Op. 156 (1988); Nassau County (N.Y.) Bar Ass'n Comm. on Prof'l Ethics, Op. 87-25 (1987); N.H. Bar Ass'n Ethics Comm., Op. 1992-93/11 (1993); N.J. Sup. Ct. Advisory Comm. on Prof'l Ethics, Op. 540 (1984); N.Y. St. Bar Ass'n Comm. on Prof'l Ethics, Op. 508 (1979); N.C. Bar Ass'n Ethics Comm., Op. RPC 36 (1988); Ohio Sup. Ct. Bd. of Comm'rs on Grievances \& Discipline, Op. 94-13 (1994); id. Op. 87-7 (1987); Ohio St. Bar Ass'n Comm. on Legal Ethics and Prof'l Conduct, Op. 94-2 (1994); Pa. Bar Ass'n Comm. on Legal Ethics \& Prof'l Responsibility, Op. 86-144 (1986); R.I. Sup. Ct. Ethics Advisory Panel, Op. 93-103 (1993); id. Op. 91-12 (1991); S.C. Bar Ethics Advisory Comm., Op. $90-37$ (1991); State Bar of S.D. Ethics Comm., Op. 88-3 (1988); Sup. Ct. of Tex. Prof'l Ethics Comm., Op. 394 (1979); Va. St. Bar Standing Comm. on Legal Ethics, Op. 856 (1986); State Bar of Wis. Standing Comm. on Prof'l Ethics, Op. E-94-4 (1994); id. Op. E-89-1 (1989); id. Op. E-80-19 (1981).

306. See, e.g., State Bar of Mich. Standing Comm. on Prof'l \& Judicial Ethics, Op. RI-141 (1992) ("If the proposed seminar were a mere informational gathering, it would serve a useful public purpose and should be encouraged.”); Miss. St. Bar Ass'n Ethics Comm., Op. 156 (1988) (finding the education of the public about legal issues to be desirable); Sup. Ct. of Tex. Prof'l Ethics Comm., Op. 394 (1979) (noting that it is proper for a lawyer to participate in a seminar the purpose of which is to impart information, but improper if the seminar's purpose is to "publicize, or make money for, its sponsors, the lawyer, or others" (citing ABA Comm. on Professional Ethics, Informal Op. 840 (1965))). Like opinions are Ala. St. Bar, Op. 87-119 (1987); State Bar of Ariz. Comm. on Rules of Prof'l Conduct, Op. 92-10 (1992); id. Op. 87-23 (1987); Fla. St. Bar Ass'n Comm. on Prof'l Ethics, Op. 75-36 (1977); Haw. Sup. Ct. Disciplinary Bd., Op. 78516 (1978); Ind. St. Bar Ass'n Legal Ethics Comm., Op. 10 (1986); Md. St. Bar Ass'n Comm. on Ethics, Op. 81-36 (1981); State Bar of Mich. Standing Comm. on Prof'l \& Judicial Ethics, Op. RI-81 (1991); Ohio Sup. Ct. Bd. of Comm'rs on Grievances \& Discipline, Op. 87-7 (1987); Pa. Bar Ass'n Comm. on Legal Ethics and Prof'l Responsibility, Op. 87-1 (1987); State Bar of S.D. Ethics Comm., Op. 88-3 (1988); Sup. Ct. of Tex. Prof'l Ethics Comm., Op. 489 (1992); Va. St. Bar Standing Comm. on Unauthorized Prac. of L., Op. 179 (1994).

307. See, e.g., State Bar of Ariz. Comm. on Rules of Prof'l Conduct, Op. 92-10 (1992); State Bar of Mich. Standing Comm. on Prof'l \& Judicial Ethics, Op. RI-141 (1992); id. Op. RI-81 
Illustrating this concern is New Hampshire Bar Opinion 199293/11, which warns lawyers against answering any questions at seminars, because an answer may confuse other listeners who attempt to use the information to solve their own problems. ${ }^{309}$ In fact, this opinion cautions that it might "be difficult to determine, even in hindsight, the extent to which the lawyer's response to individual questions at such seminars confers the status of 'client' on a member of the public ...." 310 The opinion suggests that one way of reducing the possibility of such a misapprehension is specifically to inform the attendee that no attorney-client privilege has developed from the limited interaction between the lawyer and the questioner. In addition, a

(1991); Sup. Ct. of Tex. Prof'l Ethics Comm., Op. 489 (1992); cf. In re Morin, 878 P.2d 393, 401 (Or. 1994) (per curiam) (holding that lawyer improperly allowed paralegals to give specific legal advice to clients found at "living trust" seminars).

308. State Bar of Ariz. Comm. on Rules of Prof'l Conduct, Op. 92-10 (1992). The opinion also warned that "[i]t is improper for an attorney, during the seminar to answer questions of laymen concerning their specific individual legal problems." Id.; see also Fla. St. Bar Ass'n Comm. on Prof'l Ethics, Op. 75-36 (1977) (stating that a lawyer may not give legal advice on particular legal problems to those attending a class covering general legal subjects); State Bar of Mich. Standing Comm. on Prof'l \& Judicial Ethics, Op. RI-141 (1992) (reaffirming previous opinions that discourage a lawyer from giving specific legal advice at seminars); id. Op. RI-81 (1991) (stating that a lawyer could obtain employment originating from a seminar when attendees approach the lawyer, but that the lawyer must instruct attendee to set up an appointment, rather than to begin consultation at the seminar); Ohio Sup. Ct. Bd. of Comm'rs on Grievances \& Discipline, Op. 94-13 (1994) (allowing a lawyer to accept legal employment resulting from the giving of seminars).

309. See N.H. Bar Ass'n Ethics Comm., Op. 1992-93/11 (1993). The opinion noted that the Rules of Professional Conduct do not prohibit answering questions posed by the participants, but recognized that answering questions raises particular difficulties:

Any answer, which may be entirely appropriate for the questioner, may confuse or be misapprehended by other listeners as applying to other facts. Off-the-cuff answers without an opportunity for in-depth examination of the client's situation present potential issues of competence under Rule 1.1, and the lawyer (and the audience) may be exposed to disclosure of potentially criminal or tortious acts by the questioner, which may in turn lead to difficult decisions under Rule 1.6 ... Also, as it may not be sufficiently clear whether the questioner is a client, the possible client relationship may raise problems of potential conflicts of interest with existing or former clients, which will be difficult to check under the circumstances. It may also unintentionally mislead participants as to what they can expect of the lawyer in the future. Lawyers can lessen these risks by specifically disclaiming a client relationship, and by being careful not to imply one.

Id.

310. Id.; cf. Davis v. York Int'l Corp., No. CIV.A.HAR 92-3545, 1993 WL 180224, at *2 (D. Md. May 24, 1993) (holding that, at a continuing legal education presentation, a lawyer's answering another lawyer's question about a specific case did not suffice to establish an attorneyclient relationship) 
lawyer should take every step to avoid implying that an attorneyclient relationship ever existed. ${ }^{311}$

Other bar opinions have also cautioned against lawyers giving individual legal advice at seminars. ${ }^{312}$ Bar opinions from such jurisdictions as Ohio, ${ }^{313}$ Arizona, ${ }^{314}$ and Michigan, ${ }^{315}$ for example, have stressed the importance of warning attendees that the material being

311. See N.H. Bar Ass'n Ethics Comm., Op. 1992-93/11 (1993).

312. See, e.g., State Bar of Ariz. Comm. on Rules of Prof'l Conduct, Op. 87-23 (1987) ("Anyone inquiring about specific problems must be admonished to consult an attorney for legal advice."); State Bar of Mich. Standing Comm. on Prof'l \& Judicial Ethics, Op. RI-81 (1991) (stating that the lawyer may obtain employment originating from a seminar when attendees approach the lawyer, as long as the lawyer instructs the attendees to set up an appointment, rather than to begin consultation at the seminar); Pa. Bar Ass'n Comm. on Legal Ethics \& Prof'l Responsibility, Op. 87-1 (1987) (advising lawyers who answer questions from the audience in educational courses to make clear that answers are not intended as specific legal advice); State Bar of S.D. Ethics Comm., Op. 88-3 (1988) (prohibiting lawyers from conducting seminars in which they give specific legal advice and accept requests for representation). Opinions providing similar admonitions include: Ala. St. Bar, Op. 87-119 (1987); id. Op. 86-115 (1986); State Bar of Ariz. Comm. on Rules of Prof'l Conduct, Op. $92-10$ (1992); Fla. St. Bar Ass'n Comm. on Prof'l Ethics, Op. 75-36 (1977); Haw. Sup. Ct. Disciplinary Bd., Op. 78516 (1978); State Bar of Mich. Standing Comm. on Prof'l \& Judicial Ethics, Op. RI-141 (1992); N.J. Sup. Ct. Advisory Comm. on Prof'l Ethics, Op. 540 (1984); Ohio Sup. Ct. Bd. of Comm'rs on Grievances \& Discipline, Op. 94-13 (1994); id. Op. $87-7$ (1987); Sup. Ct. of Tex. Prof'l Ethics Comm., Op. 394 (1979); Va. St. Bar Standing Comm. on Unauthorized Prac. of L. Op. 179 (1994).

313. Ohio distinguishes between seminars that offer legal information as it applies to everyone and seminars that provide individuals with unsolicited advice. See Ohio Sup. Ct. Bd. of Comm'rs on Grievances \& Discipline, Op. $87-7$ (1987) (opining that "as long as the lawyer conducting the seminar is not giving unsolicited advice that someone should obtain counsel or take legal action, or touting or recommending himself or members of his firm for employment by those in attendance," then the lawyer may conduct the seminar). Another Ohio opinion notes:

To avoid giving individual advice, it would be prudent for the lawyer to advise the attendees that the lawyer's discussion in regard to questions will be general and not intended as individual advice for specific problems. In addition, it may be helpful for the attorney to remind the attendees not to divulge confidential information.

Id. Op. 94-13 (1994).

314. See State Bar of Ariz. Comm. on Rules of Prof'l Conduct, Op. 92-10 (1992) (warning lawyers that it is improper for an attorney to answer specific individual legal questions at a seminar).

315. See State Bar of Mich. Standing Comm. on Prof'l \& Judicial Ethics, Op. RI-141 (1992):

A lawyer may not purport to deliver legal services to attendees at a seminar at which confidences and secrets of the individual attendees cannot be preserved, [because] there is little or no opportunity for the lawyer to communicate with attendees sufficient to enable the attendees to make informed decisions concerning their particular situations, [and] there is no opportunity for the lawyer to exercise independent professional judgment regarding options more suitable to a particular attendee.... 
supplied is only general information and that it should not be used to solve individual problems. The Ohio bar opinion recommends: "To avoid giving individual advice, it would be prudent for the lawyer to advise the attendees that the lawyer's discussion in regard to questions will be general and not intended as individual advice for specific problems." ${ }^{, 16}$ In a slightly different context, a Hawaii bar opinion warns that lawyers participating in a "Law Day" booth with the purpose of furnishing free legal information "must not attempt to solve the person's legal problem in particular or provide a general solution to all apparently similar personal problems that could have important functional differences." ${ }^{317}$

The bar's treatment of advice-giving in seminars parallels its historical treatment of advice-giving through mass media devices such as newspapers, radio, and television. With regard to seminars, the bar has stressed both the dichotomy between general information and specific advice and the lack of confidentiality inherent in the process. Seminar advice does carry with it some of the risks of radio and television advice in that the lawyer lacks time to reflect on the response and to ensure that there is no potential conflict of interest. In addition, at least one recent opinion on seminars has expressly recognized what was only implicit in older opinions - the risk that giving specific legal advice may inadvertently create an attorney-client relationship. ${ }^{318}$ Perhaps most relevant to our inquiry is the bar opinions' cautionary tone with respect to the efficacy of disclaimers. ${ }^{319}$ For the fullest treatment of these issues, however, we must turn to the bar opinions addressing a very recent technological advance-the 900 number.

\section{Giving Legal Advice on the Telephone Through 900 Numbers}

One final means of nontraditional legal advice-giving is the 900 number, a telephone service in which an attorney charges callers a certain amount per minute for a consultation. These services merit our particular attention because they closely parallel the exchanges

316. Ohio Sup. Ct. Bd. of Comm'rs on Grievances \& Discipline, Op. 94-13 (1994) (noting the risk in answering questions when those attending the seminar listen to an answer provided by a lawyer and act upon that information to solve their own problems).

317. Haw. Sup. Ct. Disciplinary Bd., Op. 78516 (1978).

318. See N.H. Bar Ass'n Ethics Comm., Op. 1992-93/11 (1993).

319. For example, in the bar opinions collected in notes 306-308, the presence or absence of a disclaimer does not seem to alter the warnings against giving specific advice. 
on individual websites that offer an answer to a legal question for a set fee. The bar opinions issued in the last few years have warned that the practice of using 900 numbers is rife with ethical land mines. ${ }^{320}$ The opinions have focused specifically on whether these telephone conversations create attorney-client relationships, and, if so, whether such relationships can be disclaimed. ${ }^{32}$

320. See, e.g., Ala. St. Bar, Op. 91-24 (1991) (permitting a 900-number service to provide information to nonclient creditors concerning bankruptcy matters); Kan. Bar Ass'n Comm. on Ethics/Advisory Servs., Op. 93-08 (1993) (observing that the attorney-client relationship cannot be disclaimed when advice is given via a 900-number service); id. Op. 92-06 (1992) (recognizing an attorney-client relationship when advice is given via such services and requiring lawyers to screen potential clients to ensure competency); L.A. County Bar Ass'n Prof'l Responsibility \& Ethics Comm., Op. 449 (1988) (permitting such service but requiring duties of confidentiality, competency, and avoidance of conflicts of interest); N.J. Sup. Ct. Comm. on Att'y Advertising, Op. 17 (1994) (concluding that such service is not per se unethical and that an attorney-client relationship would exist); N.Y. St. Bar Ass'n Comm. on Prof'l Ethics, Op. 664 (1994) (noting that if the relationship is limited to general advice, the client must be advised of the consequences of such limitations); id. Op. 625 (1992) (permitting general legal advice to be given, provided that callers are told that there are substantial limitations on the applicability of the information); Ohio Sup. Ct. Bd. of Comm'rs on Grievances \& Discipline, Op. 92-10 (1992) (requiring all traditional ethical duties to be applied to a 900-number service); Pa. Bar Ass'n Comm. on Legal Ethics \& Prof'l Responsibility, Op. 95-52 (1995) (noting that telephone lawyers assume all ethical responsibilities when giving legal advice); id. Op. 90-156 (1991) (requiring lawyers to screen calls initially, without charge, to determine whether they have sufficient expertise to handle the matter); Phila. Bar Ass'n Prof'l Guidance Comm., Op. 91-15 (1991) (requiring full disclosure of charges before advice is given); Utah St. Bar Ethics Advisory Opinion Comm., Op. 96-12 (1997) (noting that an attorney-client relationship is created and that all ethical rules apply); Va. St. Bar Standing Comm. on Legal Ethics, Op. 1577 (1994) (requiring that telephone clients be advised not to try to solve problems based on information provided by 900-number recordings); Va. St. Bar Standing Comm. on Unauthorized Prac. of L., Op. 185 (1995) (concluding that no attorney-client relationship is formed where "basic factual information" is provided on various legal topics). See generally John P. Gillard, Jr., Pay-PerCall Legal Advice, Professional Integrity, and Legal Licenses: Why 1-900-LAWYERS Is a Call to the Wrong Number, 79 MARQ. L. REV. 549 (1996) (examining regulations and ethical considerations governing lawyers' use of 900 numbers and weighing the benefits to society against the cost to the reputation of the legal profession); Brian S. Stuart, Note, From Heavy Breathing to Habeas Corpus: Phone Law in the Nineties, 8 GEO. J. LEGAL ETHICS 455 (1995) (discussing the potential for legal malpractice arising from the use of 900 numbers); Ann Davis, Legal Advice Lines Gain Favor, Ethical Scrutiny, NAT'L L.J., May 6, 1996, at A6 (noting the possibility of an unauthorized practice violation when a 900-number attorney is not licensed to practice in the caller's home state).

321. Some 900-number services provide only prerecorded information, rather than live conversation between an attorney and a caller. When there is no interaction between the attorney and the caller, the issue of giving specific legal advice usually does not arise, although there still may be concerns about notifying the caller about the limitations of the information provided. For example, the Virginia bar allowed a 900-number service that provided pre-recorded information about bankruptcy law, as long as the message "include[d] a statement which clarifie[d] that the message [was] general information only and not specific legal advice, and which caution[ed] the listener against trying to solve problems based on the message's general infor- 
The Kansas bar has been the most active in addressing the issue of 900 numbers, issuing two comprehensive bar opinions in the last seven years. The first opinion, Kansas Opinion 92-06, responded to the proposal of a small law firm that had been furnishing free legal advice on an 800 number and wanted to begin advertising a 900 number that would charge callers a "rough equivalent" of the firm's hourly rate. ${ }^{322}$ The service was to be called "Dial-A-Lawyer," and each call was to begin with a "recorded disclaimer [that] would indicate that only certain general advice is given, and that the firm does not take or solicit clients from such calls.",323

Opinion 92-06 does not categorically denounce this practice, although it notes that the ethical hazards it presents "may make a 900 service more of a headache than it's worth." ${ }^{324}$ Rather, the opinion

mation.” Va. St. Bar Standing Comm. on Legal Ethics, Op. 1577 (1994). In a later opinion, the Virginia State Bar said that no attorney-client relationship arises when an lawyer records a message to be played for callers using the 900-number service, as long as no legal advice is given in the message. See Va. St. Bar Standing Comm. on Unauthorized Prac. of L., Op. 185 (1995) (asserting that 900-number phone messages do not constitute the practice of law and that therefore legal ethical rules do not apply). New York Opinion 625 took a similar approach, warning that "some portion of the audience for the proposed 900 service will be composed of relatively unsophisticated members of the public" and that they should be notified of the limited nature of the information they would receive. See N.Y. St. Bar Ass'n Comm. on Prof'l Ethics, Op. 625 (1992); see also Ill. St. Bar Ass'n, Op. 97-06 (1998) (stating that charging \$15 for five minutes of prerecorded information on a 900-number service is more like a book on tape than advice, but that the $\$ 15$ may not be a reasonable fee); $c f$. Pa. Bar Ass'n Comm. on Legal Ethics \& Prof'l Responsibility, Op. 95-52 (1995) (stating that a recording is "a form of transmission of legal services" and thus subject to ethical duties). The opinion advises further:

Those duties may be mitigated by the fact that the advice which you are dispensing is general rather than specifically tailored to a particular client's requirements, but your responsibilities may be somewhat enhanced by the fact that you receive no feedback or reaction whatsoever from the listener to your telephone message, if he does not contact you thereafter. You must recognize that you are dealing with anonymous people, who may never be known to you, but who may yet rely on general telephone advice, and in the event of some misunderstanding which you are not able to clear up, perhaps rely to their detriment.

Id.

322. Kan. Bar Ass'n Comm. on Ethics/Advisory Servs., Op. 92-06 (1992) (stating that the firm planned to use the service to answer general questions about domestic relations, workers' compensation, landlord-tenant disputes, "and other relatively simple matters").

323. Id. In addition to the disclaimer, the attorneys would not handle calls from states in which they were not licensed to practice. See id. Moreover, no fee would be charged for the first minute so that those who called in error would not be billed. See id. Telephone calls would be limited to 30 minutes, and the total cost of the call "would not exceed a typical hourly rate for a similar length personal appointment." Id.

324. Id. (noting that "[t] he creation of a 900 pay-call system is not per se unethical" and that "[f]or consumers who must miss work and schedule an appointment for routine legal advice, such systems may be beneficial"). 
takes the position that "advertising that the 900 service is intended to provide 'legal advice' to those who call the service establishes the attorney-client relationship if confidential information is given., ${ }^{, 325}$ Once the exchange is characterized as an attorney-client relationship, a variety of obligations arise. As to the duty of competency, Opinion 92-06 notes that the "lawyer's duty to render competent legal advice does not depend on whether the advice is given in a law office or over the phone, whether the client was privately referred or comes to the firm because of legal advertising, or whether a fee is paid." ${ }^{326}$ The opinion notes that the lawyer must also screen 900-number clients for conflicts of interest and asserts that a blanket disclaimer at the beginning of telephone calls cannot suffice to waive such conflicts. ${ }^{327}$ Rather, " $[\mathrm{t}]$ he screening for conflicts used in the 900 service must be as thorough as conflicts checks used for new clients who come to the office." ${ }^{328}$

Opinion 92-06 identifies another troubling aspect of 900-number legal advice-the issue of client abandonment. It considers the hypothetical situation in which an accident victim calls "Dial-A-Lawyer"

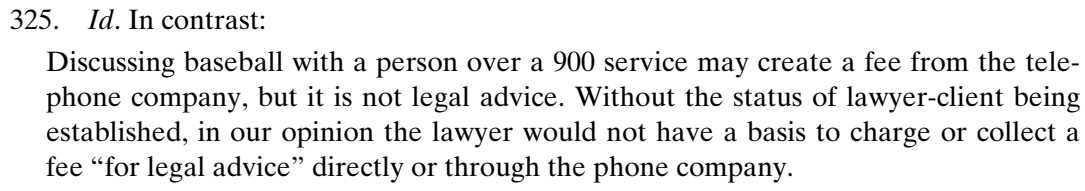

Discussing baseball with a person over a 900 service may create a fee from the telephone company, but it is not legal advice. Without the status of lawyer-client being established, in our opinion the lawyer would not have a basis to charge or collect a fee "for legal advice" directly or through the phone company. Id.

326. Id. The opinion notes that it is permissible for the service to limit its advice to simple matters under Kansas Model Rule 1.2 (c), as long as the limitation on the scope of services is truthful and is given before the clients incur billable charges. See id. Because such screening is required, the "900 'meter' cannot be switched on automatically." Id. Otherwise, a lawyer who billed when he was not competent to advise on a particular issue would likely violate Model Rule of Professional Conduct 1.5's prohibition against unreasonable fees. See id.

327. See id. The opinion states that the limitations on the advice given over the telephone are of "little value" if they otherwise violate the rule against conflicts of interest. Id. It also notes that clients have the "right to legal advice given in accord with the Model Rules of Professional Conduct," which may not be waived without consent after consultation. Id.

328. Id. The opinion further states:

The typical situation is on a Friday, Wife calls Dial-A-Lawyer about a divorce, wanting to know "her rights." During the call she imparts confidential information. On Monday husband calls the same firm using Dial-A-Lawyer. There may be a problem of counsel even talking to husband if wife gave important information relevant to the matter and that information is not otherwise generally available. The conflict is there regardless whether firm takes the wife's case. Certainly they cannot charge Husband for the 900 service when a conflict exists. Thus it is better to avoid the call at all. 
just before the statute of limitations expires on a possible negligence action. The Kansas Bar Association Committee on Ethics/Advisory Services asserts that, "for lawyers whose clients ask advice on a topic about which the lawyer is not competent to comment, the Rules create a duty to inform client of such and ensure client's decision whether and how to proceed is knowledgeable." ${ }^{329}$ Discussing the hypothetical, Opinion 92-06 states: "Having been informed of the client's jeopardy, Dial-A-Lawyer attorneys must act in a timely emergency fashion to preserve the client's rights, even if the firm says it will not take such cases directly from 900 calls." ${ }^{330}$ Because the initial telephone consultation creates a professional relationship, "that creates a positive duty to advise a client accurately and professionally to whatever extent necessary. Follow-up contacts initiated by counsel may be required." ${ }^{331}$ At a minimum, the firm must have "a policy on what it will do if the client needs a longer period for explanation" than the thirty-minute maximum identified in its advertising. ${ }^{332}$

Finally, Opinion 92-06 expressly addresses the issue of malpractice, stating that "the recorded disclaimers and actual conversations in the 900 system cannot in any way limit the liability of the firm to the client." $" 333$

In Opinion 93-08, the Kansas committee considered whether a 900-number service could structure itself to avoid the creation of attorney-client relationships and their attendant obligations. The service considered in the opinion took "great pains" to avoid formation of an attorney-client relationship, limiting itself to providing "legal information" and beginning each call with a preamble stating that "no advice is given over the line, that an attorney-client relationship is not established, nor does the right of confidentiality apply.",334

329. Id. (internal quotation marks omitted).

330. Id.

331. Id. ("Expecting the client to redial the 900-number again for further advice we believe is an improper conditioning of advice on incurring another fee."); see also Cal. St. Bar Standing Comm. on Prof'l Responsibility \& Conduct, Proposed Formal Op. 95-0015 (1995) (stating that the duty to volunteer advice is necessary "if the failure to consider such advice could result in a foreseeable adverse consequence to the client" (citing Nichols v. Keller, 19 Cal. Rptr. 2d 601 (Cal. Ct. App. 1993)).

332. Kan. Bar Ass'n Comm. on Ethics/Advisory Servs., Op. $92-06$ (1992).

333. Id. The opinion also identifies other ethical issues involving advertising, after-acquired legal work, fees, and fee-sharing with laypersons.

334. Id. Op. 93-08 (1993). The system would use CD-ROM technology to provide legal information, but "[i]f asked for an opinion on the information, answering attorney (or supervised nonlawyers) would decline to answer." Id. 
Skeptical of the claim that such a service would be an "ancillary business service" rather than the practice of law, Opinion 93-08 states unequivocally that "'legal information' in this context creates an attorney-client relationship within the purview of the Model Rules",335 and expressly denies that "an effective disclaimer can be crafted in a 900-pay-for-information service sufficient to avoid the requirements of the Model Rules." ${ }^{\text {336 }}$ Other bar opinions have also taken the position that giving legal advice on a 900-number service creates an attorney-client relationship that cannot be disclaimed. ${ }^{337}$

335. Id. The opinion also notes that if a caller wants to know what the statute of limitations is in an automobile accident, and the 900-number service provides that information, "the lawyer must assume the client will rely and act upon the information provided, whether given as legal advice or simple information." Id. Furthermore, "a fiduciary relationship is established when there is reliance, and with such reliance comes the normal duties imposed on lawyers not to abandon clients." Id. (citing Procanik v. Cillo, 543 A.2d 985 (N.J. Super. Ct. 1988)); see also N.J. Sup. Ct. Comm. on Att'y Advertising, Op. 17 (1994) (“[A]n attorney-client relationship may be found to exist if there is some 'identifiable manifestation' that a person relied on the lawyer in his or her professional capacity." (quoting In re Palmieri, 385 A.2d 856, 860 (1978)).

336. Kan. Bar Ass'n Comm. on Ethics/Advisory Servs., Op. 93-08 (1993). The opinion also rejects the proposed disclaimers as ineffective because of the prohibition against prospective waivers of malpractice liability, stating:

If the tort statute of limitation is two years and the lawyer negligently informs the client that the applicable statute is three years, client later relies on the advice and is non-suited, can lawyer then claim no malpractice liability because of all the disclaimers in the 900 service that no attorney-client relationship existed? We find no authority for that position.

Id. Opinion 93-08 also notes the possible implications for confidentiality from the attempted disclaimers, stating: "We do not believe the lawyer can counsel client to accept 'legal information' with the understanding that client confidences do not apply especially given MRPC 1.8(h) and our historical litigation holding active licensed lawyers accountable to the Model Rules of Professional Conduct irrespective of their economic pursuits." Id.; see also Cal. St. Bar Standing Comm. on Prof'l Responsibility \& Conduct, Proposed Formal Op. 95-0015 ("Using prerecorded advisory message and soliciting the caller's oral consent may be inadequate for the caller to clearly understand the limited scope of advice being provided or the significance of the limits on these services.").

337. See Ill. St. Bar Ass'n, Op. 94-11 (1997) (stating that "callers to the legal advice service are clients of the law firm who are entitled to the protection of clients afforded by [the Rules of Professional Conduct]"); L.A. County Bar Ass'n Prof'l Responsibility \& Ethics Comm., Op. 449 (1988) (stating that a "hot line" providing legal advice for a fee is allowed, but that the attorney must afford the caller all pertinent ethical duties such as confidentiality); N.J. Sup. Ct. Comm. on Att'y Advertising, Op. 17 (1994) (commenting that a 900-number disclaimer stating that the lawyers "cannot accept responsibility for the answers or advice provided" was "in contradiction of established law and public policy"); Ohio Sup. Ct. Bd. of Comm'rs on Grievances \& Discipline, Op. 93-1 (1993) (stating that a 900-number lawyer must provide clients calling the "dial-a-lawyer" service with the same protections he would afford any client coming to his office); Pa. Bar Ass'n Comm. on Legal Ethics \& Prof'l Responsibility, Op. 95-52 (1995) (recognizing that a recorded message by a lawyer explaining general real estate law may be done 
Although most jurisdictions that have considered the issue treat 900-number conversations as creating attorney-client relationships, a minority view permits the lawyer to give advice without triggering such a relationship. New York State Bar Opinion 664 indicates that the attorney "should provide disclosure of the extent of the advice being offered and the extent of the attorney-client relationship created during the telephone conversation." ${ }^{338}$ In so doing, "a lawyer may restrict his or her representation to the provision of general advice on legal problems that frequently arise." 339 The opinion further reasons that many laypeople "may appreciate (1) a discussion of general areas of law that are more tailored to their particular situation than a book or article might be, or (2) a quick identification of the le-

through a 900-number service, but cautioning that this activity brings with it the ethical responsibilities arising when legal advice is given); $i d$. Op. 90-156 (1991) (requiring a lawyer to screen calls to determine if he is competent to provide the advice sought); Phila. Bar Ass'n Prof'l Guidance Comm., Op. 91-15 (1991) (opining that the lawyer must be competent to answer the questions asked before advising the caller); Utah St. Bar Ethics Advisory Opinion Comm., Op. 96-12 (1997) (stating that "if the advice sought is pertinent to the attorney's profession, and if the attorney gives the advice for which fees will be charged, an attorney/client relationship is created that cannot be disclaimed by the attorney giving the advice"). California's proposed Formal Opinion 95-0015 takes a position similar to that of Kansas. See Cal. St. Bar Standing Comm. on Prof'l Responsibility \& Conduct, Proposed Formal Op. 95-0015 (citing Perkins v. West Coast Lumber Co., 62 P. 57 (Cal. 1900)). The opinion noted that "[w]hen a party seeking legal advice consults an attorney and secures that advice, however, the relation of attorney and client is established prima facie," and it rejected disclaimers as both insufficient to avoid creating such a relationship and possibly violating the rules against false or misleading statements. $I d$. Virginia Opinion 1328 addressed a variation of these services, in which a lawyer established a 900-number service promising to answer any legal questions for a year, via the telephone, for a certain price. See Va. St. Bar Standing Comm. on Legal Ethics, Op. 1328 (1996). The opinion stated that whenever legal advice is provided by a lawyer to a person, whether in person or over the telephone, an attorney-client relationship exists. See id.

338. N.Y. St. Bar Ass'n Comm. on Prof'l Ethics, Op. 664 (1994). The opinion recommends that the lawyer inform the caller:

(1) that some legal issues may be too complex to result in clear, concise and complete responses by telephone, (2) whether the lawyer will restrict his or her representation to advice of general applicability or whether the advice will be sufficiently tailored to the specific facts at hand to constitute complete legal advice, (3) the arrangements that will be made if competent representation would require legal research, review of documents and advice that cannot be provided during the initial telephone call, and (4) whether the representation is limited to telephone advice or also encompasses other steps ....

Id.

339. Id. (citing Model Code of Professional Responsibility EC 2-2 (1980)). New York has not adopted the Model Rules of Professional Conduct. 
gal issues involved, even if the discussion is general, and does not provide any answers to the issues raised."

In light of the case law previously reviewed, as well as the long history of bar regulation of advice-giving, the Kansas approach seems far more consistent with the traditional understanding of the attorney-client relationship. The New York opinion acknowledges that some kind of attorney-client relationship is created, but also assumes that only general information is to be transmitted by the lawyer. As we have seen, transmitting general information has rarely been characterized as sufficient to create an attorney-client relationship. On the other hand, paying a fee for legal advice has ordinarily been strong evidence of a professional relationship. As Utah Opinion 9612 explains: "[I]f legal advice is sought from an attorney, if the advice sought is pertinent to the attorney's profession, and if the attorney gives the advice for which fees will be charged, an attorney-client relationship is created that cannot be disclaimed by the attorney giving the advice." ${ }^{341}$ Moreover, the New York opinion does not fully analyze how far the lawyer may go in disclaiming responsibility for the advice he gives, nor does it address whether certain disclaimers might be void as against public policy, since most people will not pay for legal advice, in any guise, unless they expect to be able to rely on it. ${ }^{342}$

These divergent approaches reflect an emerging tension in the area of nontraditional advice-giving. The majority apparently assumes that conduct creating an attorney-client relationship is to be avoided at all costs, either by way of disclaimer or by studiously

340. Id. Under this approach, 900-number advice services are consistent with the admonition of Ethical Consideration 2-2 to help the public to recognize legal problems. Other jurisdictions have noted the difficulties in finding an attorney-client relationship emerging from 900number conversations. See, e.g., Iowa Sup. Ct. Bd. of Prof'l Ethics \& Conduct, Op. 93-1 (1993) (asserting that 900-number services are improper for Iowa lawyers, although "it is difficult to see how such a relationship can arise out of an initial contact by telephone, without personal confrontation and without means to identify or otherwise personally to relate to the inquirer"); Ohio Sup. Ct. Bd. of Comm'rs on Grievances \& Discipline, Op. 92-10 (1992) (opining that it seems unusual when legal advice is given to a caller with whom the lawyer has no previous professional affiliation or relationship). The Iowa opinion noted, however, that such relationships could develop and impose substantial duties on the lawyer. See Iowa Sup. Ct. Bd. of Prof'l Ethics \& Conduct, Op. 93-1 (1993).

341. Utah St. Bar Ethics Advisory Opinion Comm., Op. 96-12 (1997) (citing BreyerHarrison, Inc. v. Combe, 799 P.2d 716, 707 (Utah 1990)).

342. See N.J. Sup. Ct. Comm. on Att'y Advertising, Op. 17 (1994) (explaining that "consumers will not call if they do not have specific problems for which they need advice-advice on which they intend to rely" and that "[c]onsequently, they will have every reason to believe . .. that an attorney-client relationship will exist"). 
avoiding the giving of specific legal advice. The New York opinion, however, comes close to advising that the lawyer create some kind of limited professional relationship by way of disclaimer, without explaining the ramifications of such limitations.

\section{E. Giving Legal Advice in Cyberspace}

As yet, only a few bar opinions have discussed the ramifications of giving legal advice to strangers in cyberspace, and none has attempted to analyze this question in light of the case law or the history of regulating analogous conduct. In an early discussion of the subject, South Carolina Opinion 94-27 permitted online legal discussions "solely for the purpose of discussing legal topics generally, without the giving of advice or the representation of any particular client.",343 That same year, Oregon Bar Opinion No. 1994-137 permitted the development of an online legal data base that would furnish information to inquirers, but would not provide live communication. The opinion noted that "if someone at the legal information service were generating legal advice during an on-line session by giving personal advice, that is the practice of law." ${ }^{344}$ Tennessee Advisory Ethics Opinion 95-A-576 permitted lawyers to respond to laypersons' requests through private e-mail, but cautioned that providing specific legal information could create an attorney-client relationship. ${ }^{345}$ Arizona Bar Opinion 97-04 recommended that lawyers should "probably not" answer questions raised in online chat rooms because of the inability to check for potential conflicts of interest and the risk of disclosing confidential information. ${ }^{346}$ It continued: "Ethically, it would follow that lawyers should not answer specific legal questions from lay people through the Internet unless the question presented is of a general nature and the advice given is not fact-specific." ${ }^{\text {347 }}$

Some opinions have indicated that online exchanges can create attorney-client relationships. The most emphatic on this score is Illi-

\footnotetext{
343. S.C. Bar Ethics Advisory Comm., Op. 94-27 (1995). The opinion further stated that if the lawyer wished to represent clients through online activities, the lawyer would have to "obtain sufficient information to identify his client in order to make a complete conflicts inquiry." Id.

344. Or. St. Bar Ass'n Legal Ethics Comm., Op. 1994-137 (1994).

345. See Tenn. Sup. Ct. Bd. of Prof'l Responsibility, Op. 95-A-576 (1995) (unpublished opinion) (on file with the Duke Law Journal).

346. State Bar of Ariz. Comm. on Rules of Prof'l Conduct, Op. 97-04 (1997).

347. Id.
} 
nois Bar Opinion 96-10, which states that "lawyers participating in chat-groups or other on-line services that could involve offering personalized legal advice to anyone who happens to be connected to the service should be mindful that the recipients of such advice are the lawyer's clients, with the benefits and burdens of that relationship." ${ }^{348}$ Somewhat less definitive is Philadelphia Bar Opinion 98-6, published in 1998, which considers a hypothetical situation in which a lawyer who has filed a class action against a corporation later participates in an online discussion group in which questions are raised about the suit by participants. Opinion 98-6 identifies a number of potential ethical concerns that might arise from any responses the lawyer might give. ${ }^{349}$ It also notes that the lawyer must be cautious about not creating, albeit inadvertently, an attorney-client relationship, which begins "when a person would have a reasonable expectation that such a relationship was formed." ${ }^{350}$ The opinion recommends a disclaimer.

More recently, two opinions from New York have discussed lawyer activity on the Internet. New York Opinion 709, issued in September of 1998, considers a number of ethical issues arising from a lawyer's intended use of a website in connection with a business that would "conduct trademark searches, render legal opinions on availability of trademarks, and file and prosecute applications to register trademarks." ${ }^{351}$ The attorney had planned to give legal opinions on the telephone, but otherwise to use unencrypted e-mail to communicate with clients. Noting that using the Internet to practice law is "analogous to conducting a law practice by telephone or facsimile machine," the opinion concludes that the various obligations of traditional client representation would inhere in this practice as well. ${ }^{352}$ It reiterates the New York committee's position in the 900-number dis-

348. Ill. St. Bar Ass'n, Op. 96-10 (1997).

349. See Phila. Bar Ass'n Prof'l Guidance Comm., Op. 98-6 (1998) (warning that the lawyer must be concerned about truthfulness to third parties, must beware of the dangers of remaining anonymous, must be concerned about the likelihood that newsgroup participants might be located in jurisdictions in which the lawyer is not licensed to practice, and must be cautious about violating rules against solicitation).

350. Id.

351. N.Y. St. Bar Ass'n Comm. on Prof'l Ethics, Op. 709 (1998) (stating that the duties include complying with state requirements to post a statement of client rights and responsibilities, conducting adequate conflicts checks, ensuring competency, preserving confidentiality, and avoiding solicitation).

352. Id. The opinion also warns of the dangers of providing legal services to clients outside of New York without considering the possibility of unauthorized practice of law. See id. 
cussion $^{353}$ that "a conflicts check is not required where the attorney's interaction is limited to providing general information of an educational nature, no confidential information is obtained from a client and no specific advice tailored to a client's particular circumstances is rendered." ${ }^{354}$

New York City Opinion 1998-2 addresses a similar proposal for a website providing trademark searches and other intellectual property-related services. ${ }^{355}$ The firm also wished to establish a "listservtype discussion area on the subject of general intellectual property and legal issues." ${ }^{356}$ The opinion advises that lawyers participating in the discussion should employ "substantial caution and vigilance" to avoid giving or appearing to give specific legal advice. ${ }^{357}$ The opinion adds that a disclaimer might not shield the firm against a claim that specific online communication had established an attorney-client relationship. ${ }^{358}$

\section{F. The Past Is Prologue}

The legal profession's historical hostility to giving specific legal advice to laypeople outside the confines of traditional attorney-client relationships is unlikely to disappear overnight, regardless of how attractive the new medium of computer technology may appear to some lawyers. Although such vehement technophobes as Clarence Seward may be fewer in number today, ambivalence about the effect of the Internet on traditional law practice remains, and the opinions addressing Internet advice-giving perpetuate the seventy-year pattern of skepticism toward nontraditional forms of legal advice. This is not to suggest that such concerns have no merit. Unregulated use of the Internet to dispense legal advice is fraught with peril, both for the unsuspecting layperson seeking such advice and for the lawyer who carelessly produces it. But it is important for the legal profession to remember that the peril arises not from the technology itself, but from the failure to harness its power appropriately.

\footnotetext{
353. See supra notes 338-340 [xref] and accompanying text.

354. N.Y. St. Bar Ass'n Comm. on Prof'l Ethics, Op. 709 (1998).

355. See Ass'n of the Bar of the City of N.Y. Comm. on Prof'l \& Judicial Ethics, Op. 1998-2 (1998).

356. Id.

357. Id.

358. See id.
} 
Having offered some observations about the risks inherent in permitting Internet advice-giving to continue without scrutiny by the organized bar, I conclude with some reflections on how this aspect of the new medium ought to be regulated. The difficult question facing the profession is whether the potential of this technology to serve the legal needs of millions of people can be fully harnessed within the traditional model of an attorney-client relationship, or whether the profession ought instead to embrace recent proposals for the recognition of a more limited form of professional relationship that would permit lawyers to give specific legal advice to willing laypeople without incurring all the duties that would ordinarily follow. Resolving this issue in a way that both protects the public and maximizes the potential of this new technology will be one of the principal challenges for our profession in the next century.

\section{CONCLUSION}

\section{A. The Peril}

The peril that arises from unregulated advice-giving on the Internet is two-fold. The peril to laypeople seeking legal advice by posting questions online is that they will receive bad advice and rely on it to their detriment. The peril to an unwary lawyer who gives legal advice to strangers online is that a stranger who is harmed by such advice will seek recourse through either a civil suit or a disciplinary complaint with the bar. As my review of the applicable law demonstrates, many of the exchanges between lawyers and laypeople in cyberspace that we considered at the beginning of this Article could be viewed as creating attorney-client relationships, provided the lawyer gives specific legal advice. The perils of unbridled advice-giving online are particularly acute in certain contexts because some Internet exchanges are more likely than others to create attorney-client relationships. This is especially true of exchanges in which the layperson pays the lawyer for the advice given. The payment of a fee and the more confidential nature of these e-mail exchanges are likely to be sufficient indicia that reliance on the advice was reasonable. But even free e-mail exchanges are likely to suffice if the lawyer gives specific legal advice. Similarly, lawyers who answer questions posted on sites like Dear Esquire and FreeAdvice likely are creating attorney-client relationships by giving specific legal advice tailored to the questioner's individual situation. Even conversations in discussion groups 
and chat rooms may ripen into attorney-client relationships if lawyers give detailed legal advice to specific individual questioners. On the other hand, more general postings to such groups, or even specific legal comments that are not tailored to individual questions, are unlikely to generate reasonable reliance on the information given.

In each of these settings, disclaimers are unlikely to provide the blanket protection so many lawyers apparently seek, especially if the legal advice given is particularized to the inquirer's factual situation. Neither courts nor bar counsel is likely to be sympathetic to lawyers who have given negligent advice and then try to rely on boilerplate disclaimers to absolve them of responsibility for harm. The courts have been especially protective of laypeople when lawyers attempt to enforce contracts against them, ${ }^{359}$ and this view is likely to apply with particular force in cyberspace transactions. That is not to suggest that lawyers will be unable to defend themselves against such claims ${ }^{360}$ but rather to caution that the case law and historical precedent cast substantial doubt on the ability of lawyers to avoid the consequences of giving specific legal advice. Only the most foolhardy of lawyers would

359. See generally WOLFRAM, supra note $98, \S 9.1$, at 497 (stating that courts scrutinize legal-fee contracts more stringently than other contracts because the lawyer acts as a fiduciary agent for the client).

360. One possible defense we have not discussed is a First Amendment challenge, in which a lawyer disciplined for negligent advice-giving online claims that restrictions on lawyer advicegiving in cyberspace are unconstitutional infringements of the right of free speech. A full treatment of this argument is beyond the scope of this Article, but I believe such a claim is likely to be rejected on the ground that the giving of specific legal advice is conduct, not speech. The Supreme Court has endorsed restrictions on attorney speech in a variety of different contexts, including: limitations on public comments about pending cases, see Gentile v. State Bar, 501 U.S. 1030 (1991); in-person solicitation of clients, see Ohralik v. Ohio State Bar Ass'n, 436 U.S. 447 (1978); and mail solicitations targeted at accident victims and their families, see Florida Bar v. Went For It, 515 U.S. 618 (1995). A court is unlikely to find that lawyers have a First Amendment right to give negligent advice and thereby to commit malpractice. At the same time, courts have acknowledged in the context of unauthorized practice of law that the line between general information and specific legal advice must be carefully drawn to avoid infringing on protected speech. See Unauthorized Practice of Law Comm. v. Parsons Techs., Inc., No. 97-2859, 1999 WL 47235, at*10 (N.D. Tex. Jan. 22, 1999) (finding that application of an unauthorized practice statute to computer software providing legal information did not violate the First Amendment), rev'd 179 F.3d 956 (5th Cir. 1999) (per curiam) (recognizing that a recent amendment to the unauthorized practice statute, An Act Relating to the Definition of the Practice of Law, 1999 Tex. Sess. Law Serv. 799 (West), superseded the holding of the district court); Florida Bar v. Brumbaugh, 355 So. 2d 1186, 1193-94 (Fla. 1978) (per curiam) (holding that a ban on the sale of printed material purporting to explain legal practice and procedure, as well as on a secretarial service's typing legal forms, violates the First Amendment); see also Rhode, supra note 180, at 62-70 (examining First Amendment implications of unauthorized practice prohibitions). 
gamble a license to practice law on the odds that a reviewing court would respect a boilerplate disclaimer of responsibility for attorney negligence or incompetence.

Our natural concern about these very real dangers, however, must not dictate our reaction to the phenomenon of Internet legal advice. Although the dangers from unchecked use of computer technology to provide legal advice to strangers are real, they are not the inevitable byproduct of that technology. It is human error and human frailty, not the mere existence of new communication devices, that lead to negligence and ethical violations. This reality is often obscured by an overreaction to new technology. Indeed, when use of the Internet began to expand several years ago, some firms sharply restricted its availability because of concerns that employees might view inappropriate sites or otherwise waste time. They apparently failed to consider that the average employee probably wastes more time with the decidedly non-technological morning newspaper or with real-time gossiping at the water cooler. ${ }^{361}$ The legal profession must be wary of similarly overreacting to the new medium without giving due consideration to the great potential benefit of the underlying conduct that it facilitates. ${ }^{362}$

361. See David Beckman \& David Hirsch, Internet: Who Needs It?: Law Office Managers Must Set Policy for Online Access and Limitations, A.B.A. J., Apr. 1996, at 93 (describing a law firm policy that banned staff from access to the Internet from their terminals because the firm "didn't want to invite trouble"); Joe Dysart, Establishing an Internet Policy, CREDIT UNION EXECUTIVE, May-June 1998, at 18 (describing policies used by companies to block or control access); Wendy R. Leibowitz, 'Netiquette' from Miss Manners, Kraft, Dickstein Shapiro, et al., NAT'L L.J., Jan. 27, 1997, at B11 (noting that 55 of 115 law firms surveyed in 1996 had limitations on Internet access); Michael Tarsala, Futz Up? Too Much Goofing Off, That's What, INVESTOR's BUS. DAILY, Mar. 11, 1998, at A11 (highlighting the loss in employee productivity from abuse of Internet access). In 1997, the U.S. Senate passed a House of Representatives appropriations bill after amending it to prevent federal government employees from having access to computer games such as Solitaire on their office computers. See S. 1023, 105th Cong. (1997); 143 ConG. REC. S9510 (daily ed. Sept. 17, 1997). However, the amendment failed to pass in the House, perhaps in part because of the substantial costs inherent in removing games from thousands of government computers. See Leslie Goff, Not Playing Around, COMPUTERWORLD, Dec. 1,1997 , at 83,84 . There is no record of any similar attempt to ban government employees from bringing the Washington Post into their offices in order to ensure that they do not waste time on the crossword puzzle. See Amy Harmon, On the Office PC, Bosses Opt for All Work, and No Play, N.Y. TIMES, Sept. 22, 1997, at A1 (noting Senate passage of a bill to remove Solitaire from office computers).

362. See Josh Blackman, Legal Practice in Cyberspace, L. OfFICE ComPuTING, Oct.-Nov. 1995, at 64 (suggesting online communication as a means of "bridging the client/attorney gap"). 


\section{B. The Promise}

Computer technology as it now exists-doubtless considered rudimentary in five years-permits laypeople to have their legal questions answered promptly in writing by a practicing attorney at low cost, without having to make appointments and to travel to the lawyer's office. This revolutionary technology has the potential to serve the unmet legal needs of millions of Americans of low and moderate income who cannot afford to hire attorneys, at a time when the number of lawyers in the United States continues to expand. ${ }^{363}$ The challenge to the legal profession is to nurture this nascent potential, while at the same time protecting the public against negligent advice. Starting from the premise that online advice-giving creates an attorney-client relationship, we therefore must inquire whether there is room within the existing regulatory framework for a professional arrangement that is limited to a mere exchange of question and answer. ${ }^{364}$

If the bar were explicitly to recognize that giving specific legal advice online creates a traditional attorney-client relationship, what

363. An invaluable resource on this issue is the record of the Conference on the Delivery of Legal Services to Low-Income Persons, held at Fordham Law School in December 1998. See Recommendations of the Conference on the Delivery of Legal Services to Low-Income Persons, 67 Fordham L. REV. 1751 (1999) [hereinafter Conference on the Delivery of Legal Services]. For a critique of the inequitable distribution of legal services, see Deborah Rhode, Symposium, The Future of the Legal Profession: Institutionalizing Ethics, 44 CASE W. RES. L. REV. 665, 682 (1994) (noting that half of all lawyers' time is spent on clients in the top $15 \%$ of income distribution); see also Albert H. CANTRIL, Agenda for ACCESS: THE AMERICAN PEOPLE AND CIVIL JUSTICE vii-viii (1996) (noting that the private bar and publicly funded legal services programs now serve only a small portion of the legal needs reported by low-income households).

364. In light of the case law we have already reviewed, as well as a long history of treating similar conduct as creating an attorney-client relationship, it seems highly unlikely that courts would exempt Internet advice-giving from the traditional approach, especially when the alternative would be to leave lay questioners with no legal recourse. Although some of the commentary at the Fordham Conference suggests that the relationship might be understood as that of a "prospective client," once specific advice is given, as in Togstad, this fiction is far more difficult to maintain. See Bruce A. Green, Foreword: Rationing Lawyers: Ethical and Professional Issues in the Delivery of Legal Services to Low-Income Clients, 67 FORDHAM L. REV. 1713, 1729 (1999) (noting that it is "unclear" whether recipients of brief advice are clients, but questioning whether they could fairly be treated as nonclients to whom no duties were owed); Mary Helen McNeal, Having One Oar or Being Without a Boat: Reflections on the Fordham Recommendations on Limited Legal Assistance, 67 FORDHAM L. REV. 2617, 2625 n.39 (1999) (noting that characterizing the questioner as a prospective client may be "fiction"). 
would the ramifications be for lawyers in cyberspace $?^{365}$ By giving the advice, the lawyer would incur core obligations to the client that could not be disclaimed. First, the lawyer must ensure that she has no conflict of interest that would preclude furnishing objective advice. ${ }^{366}$ Second, the lawyer must give competent advice, obtaining whatever information is necessary from the questioner and doing whatever research is required to provide such advice. ${ }^{367}$ Third, the lawyer must inform the questioner about the benefits of confidentiality, even if a question has been posted publicly, and she ordinarily would be expected to keep all communications confidential, unless specifically authorized by the recipient to make them public. ${ }^{368}$

These familiar duties of loyalty, competency, and confidentiality fit comfortably with the limited model of Internet question and answer that we are considering. In fact, one might argue that carrying out these duties might actually be easier in the online environment, because e-mail allows lawyers and their clients to communicate cheaply and efficiently, from almost anywhere, at any hour of the day or night. Moreover, e-mail communications can be preserved as a record of the transaction. The ability to retain a complete record of these communications could be a powerful tool for bar regulators. A requirement that lawyers who give legal advice in cyberspace keep copies of all communications for a certain period of time would facilitate the resolution of subsequent conflicts over whether the lawyer's conduct comported with applicable rules. ${ }^{369}$

Yet, the one duty we have not yet addressed is the most problematic-the duty of diligence (once more commonly known as the duty of zealous representation). Although the innocuous wording of

365. For a discussion of some of these issues as they might arise in the context of giving brief legal advice, see generally Richard Zorza, Response to the Conference: Re-Conceptualizing the Relationship Between Legal Ethics and Technological Innovation in Legal Practice: From Threat to Opportunity, 67 FORDHAM L. REV. 2659 (1999).

366. See Model Rules of Professional Conduct Rule 1.7 (1998).

367. See id. Rule 1.1.

368. See id. Rule 1.6.

369. Similar recordkeeping requirements already exist with respect to financial records, see id. Rule 1.15, and certain forms of advertising, including attorney websites, see id. Rule 7.2. The requirement to keep copies of e-mail would not seem to be any more burdensome than other types of files kept by attorneys, and the maintenance of confidentiality ought not to be at issue, since ordinarily the only reason for bar regulators to seek access to these documents would be in response to a complaint by a disappointed client, who always has the ability to consent to disclosure. See id. Rule 1.6 (mandating confidentiality of information relating to representation unless the client consents after consultation). 
Model Rule of Professional Conduct 1.3 simply states that "[a] lawyer shall act with reasonable diligence and promptness in representing a client," ${ }^{370}$ this requirement historically has been understood to commit the lawyer to take all lawful steps necessary to protect a client's interests. ${ }^{371}$ Can this duty be met when a lawyer gives a client specific legal advice, but does not volunteer additional information about other legal issues that might lurk beneath the surface? If the lawyer concludes that immediate legal action is required to protect the lay questioner, is the lawyer obligated to take such action on the questioner's behalf? Or can the lawyer limit the legal relationship to the furnishing of specific legal advice? Ordinarily, once an attorney-client relationship has been created, the lawyer must protect the client's interests and must not abandon the client. The Model Rules impose substantial limitations on the ability of a lawyer to withdraw from an existing professional relationship and require that even upon termination of the relationship, the lawyer "shall take steps to the extent reasonably practicable to protect a client's interests." ${ }^{372}$ Moreover, as I noted previously, the courts are unlikely to view sympathetically a lawyer's attempt to have the client consent to bargaining away a core duty like that of diligence. ${ }^{373}$

For some lawyers, the imposition of a full-fledged attorney-client relationship upon the giving of specific legal advice might be an acceptable aspect of practicing law in cyberspace. Indeed, for lawyers committed to a new type of law practice in which the bulk of their client base will come from the Internet, the idea that giving specific legal advice online may obligate the lawyer to perform additional services for the recipient may have little impact on that practice, other than to reinforce the obligation not to dispense such advice lightly. But for many other lawyers, who might be willing to provide

370. Id. Rule 1.3.

371. See id. Rule $1.3 \mathrm{cmt}$.:

A lawyer should pursue a matter on behalf of a client despite opposition, obstruction or personal inconvenience to the lawyer, and may take whatever lawful and ethical measures are required to vindicate a client's cause or endeavor. A lawyer should act with commitment and dedication to the interests of the client and with zeal in advocacy upon the client's behalf.

For a thoughtful critique of this model, see generally Fred Zacharias, Limited Performance Agreements: Should Clients Get What They Pay For?, 11 GeO. J. LEGAL ETHICs 915 (1998) (criticizing legal and professional standards governing limited performance agreements as dishonest).

372. Model Rules of Professional Conduct Rule 1.16(d) (1998).

373. See supra notes 148-152 [xref] and accompanying text. 
brief legal assistance in cyberspace but not to undertake further responsibilities, the application of the traditional professional model may discourage their participation.

In light of this dilemma, the most difficult issue for the profession is whether to recognize a more limited form of client representation in which a lawyer and client agree to establish certain boundaries to the relationship, such as limiting the lawyer's duty simply to providing competent legal advice on a specific problem. Although the potential benefits of encouraging more limited relationships should not be ignored, ${ }^{374}$ the substantial ethical issues arising from this development remain troubling. ${ }^{375}$ The idea of "discrete task representation," sometimes called "unbundling" legal services, has surfaced in recent years as a possible remedy to unmet legal needs. The model is that of a menu of legal tasks from which the client, in consultation with the lawyer, is permitted to purchase only the services that he needs and can afford. ${ }^{376}$ By unbundling these services, the lawyer can give at least limited assistance to the person who needs help, without incurring other weighty obligations, and the client can obtain recourse that he otherwise could not obtain. In many ways, giving specific legal advice to clients online, while expressly disclaiming any additional responsibilities, is a classic example of discrete task representation.

374. For an optimistic view of this potential, see generally Zorza, supra note 365.

375. Some general discussion of these concerns appears in the Report of the Working Group on Limited Legal Assistance, 67 FoRDHAM L. REV. 1819 (1999).

376. For discussions of discrete task representation, see generally Mary Helen McNeal, Redefining Attorney-Client Roles: Unbundling and Moderate-Income Elderly Clients, 32 WAKE FOREST L. REV. 295 (1997) (suggesting discrete task representation as a solution to legal problems for elderly clients who can neither afford legal services nor qualify for free legal aid); Michael Millemann et al., Rethinking the Full-Service Representational Model: A Maryland Experiment, 30 CLEARINGHOUSE REV. 1178 (1997) (concluding that a limited representational model for legal services would provide increased availability of legal information and increased public confidence in the administration of justice); Forrest S. Mosten, Unbundling of Legal Services and the Family Lawyer, 28 FAM. L.Q. 421 (1994) [hereinafter Mosten, Family Lawyer] (discussing barriers to serving as legal counsel to pro se litigants in the realm of family law and recommending a preventative approach to legal counseling); Forrest S. Mosten, Unbundling Legal Services: A Key Component in the Future of Access to Justice, OR. ST. B. BULl., Jan. 1997, at 9 [hereinafter Mosten, A Key Component] (recommending removal of ethical, malpractice, and attitudinal barriers to unbinding of legal services); Lonnie A. Powers, Pro Bono and Pro Se: Letting Clients Order off the Menu Without Giving Yourself Indigestion, BosT. B.J., May-June 1998, at 10 (discussing the ethical considerations when advising pro se litigants about discrete issues on a pro bono basis). 
The issue of limited representation recently has come to the forefront in recommendations developed and adopted at the Conference on the Delivery of Legal Services to Low-Income Persons, held at Fordham University Law School in December $1998 .{ }^{377}$ Among the many recommendations adopted were a series of proposals to encourage so-called limited legal assistance. ${ }^{378}$ The recommendations note that "[r]ecent experiments in the delivery of legal servicessome but not all driven by technology-suggest the possibility of significant increases in access to services, provided the rules governing the practice of law are not interpreted to inappropriately narrow the delivery and evolution of services." ${ }^{379}$ In response to these experiments, the conference recommendations identify three general categories of legal assistance: "(1) traditional, 'full-service' representation; (2) limited legal assistance; and (3) general advice." 380 Within the "limited legal assistance" category are two subdivisions: "brief, specific advice" and "assistance requiring a diagnostic interview." ${ }^{381}$

Although the recommendations do not explicitly explore advicegiving on the Internet, the conference's notion of "brief, specific advice" clearly encompasses such conduct. ${ }^{382}$ The recommendations define "brief, specific advice" as "answering a specific question or limited set of related questions without follow up or exploration by the legal services provider," noting further that "the client must be advised that the service is limited to brief advice only." ${ }^{383}$ The recom-

377. See Conference on the Delivery of Legal Services, supra note 363.

378. Id. at 1774-78, Recs. 47-64.

379. Id. at 1774 , Rec. 48.

380. Id. at $1775-76$, Rec. 59.

381. Id. at 1776 , Rec. 60.

382. The two examples of "brief, specific advice" are:

(i) Potential client calls legal services office and states, "My boyfriend registered his car in my name because he had so many parking tickets. Now, he has more parking tickets under my name. Do I have to pay them?" The answer is "yes."

(ii) Consumer calls legal services office and states that she was turned down for credit and that her credit report is incorrect, and asks what she should do. Legal worker advises her how to get a copy of her credit report, that the report is free, and the steps she should take to get the credit reporting agency to revise the information.

Id. at 1776, Rec. 60 . The recommendations advocate further study of how to govern a variety of methodologies, including "hotlines, websites (informational, unintelligent form fill-in, intelligent form fill-in, email with an attorney, and online videoconferencing), ghostwriting, pro se clinics, unbundled services, form pleadings, community education, and those methodologies to be developed in the future." Id. at 1778, Rec. 63.

383. Id. at 1776, Rec. 60(a). 
mendation contemplates that the lawyer providing such service would be bound by the traditional duties of confidentiality, competence, and loyalty, but that " $\mathrm{t}]$ he lawyer or legal services program has no duty to provide complete assistance with respect to the individual's legal problem." ${ }^{384}$ Moreover, that recommendation suggests that the duty of loyalty ought not to be construed to restrict the lawyer with respect to potential conflicts of interest "to the same degree as the lawyer who renders more extensive representation." require lawyers engaged in this practice to develop systems to safeguard against disclosure of client confidences and the emergence of conflicts of interest. ${ }^{386}$ In the second form of this service, "assistance requiring a diagnostic interview," the recommendation contemplates that the lawyer "shall elicit sufficient facts to enable an appropriate decision as to the limited service(s) to offer the client and for the client to make an informed decision about how to proceed." 387 Again, once the limited services have been provided, "the lawyer or legal services program has no further obligation with respect to this client." 388

The recommendations do not clearly state whether these proposals represent an interpretation of existing law or a blueprint for changing the law. In particular, although the recommendations use the term "client" with respect to the recipient of the "brief, specific advice," they also assert that one traditional duty owed to clientsthe duty of fully representing the client, or the duty of diligence-simply will not apply in this context. The recommendations essentially sidestep this dilemma by asserting that "[r]ules regarding the administration of justice, rules governing the practice of law, and rules prohibiting the unauthorized practice of law should not be created, advanced, interpreted, or applied so as to obstruct such efforts to increase access." ${ }^{389}$ There is only a feeble attempt to resolve the complex ethical issues posed by this new scheme:

The application of the above recommendations to current ethical provisions, including standards of competence and diligence, confi-

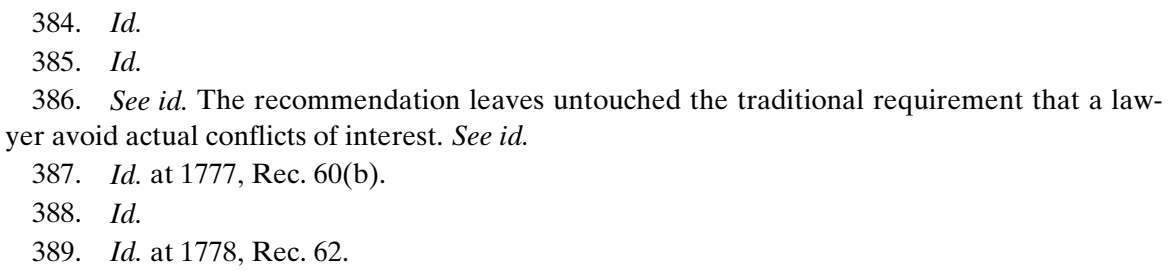


dentiality, and conflicts of interest, needs concrete assessment and evaluation, particularly with respect to the impact on clients and the resolution of their legal problems or questions. ${ }^{390}$

In contrast to the conference recommendations, which essentially argue for a gloss on existing law, there currently is at least one proposal to amend the Model Rules of Professional Conduct to permit more limited forms of the attorney-client relationship. The ABA has created a group called the Ethics 2000 Commission to consider reform of the Model Rules. ${ }^{391}$ John Jenkins, chair of the ABA's Standing Committee on the Delivery of Legal Services, has suggested amending Model Rule 1.2(c) or its comment to recognize that "limitation of the objectives of a representation is especially appropriate when lawyers render advice to moderate-income consumers through nontraditional methods such as a telephone 'hotline." ${ }^{392}$ Although this recommendation stems in part from some lawyers' unwillingness to participate in telephone hotline programs, the rationale presumably would be applicable to cyberspace as well.

What would be the best approach to facilitating limited representation in cyberspace? In my view, neither existing case law nor the ethical rules as they are currently written would permit the type of sharply limited professional relationship contemplated by the Fordham Conference. The Model Rules impose a variety of duties upon the formation of attorney-client relationships ${ }^{393}$ and require that they be fulfilled even in difficult circumstances, such as in the representation of impaired clients. ${ }^{394}$ Merely to announce that lawyers in such

390. Id. Rec. 64.

391. See Ethics 2000 Commission Hears Plenty of Suggestions for Reforming Model Rules, 66 U.S.L.W. 2789, 2789 (June 23, 1998).

392. Id. at 2790. The full testimony is available on the World Wide Web. See Testimony of John S. Jenkins (visited Sept. 15, 1999) <http://www.abanet.org/cpr/jenkins.html> (on file with the Duke Law Journal). His recommended change to Model Rule 1.2(c) is to add the sentence: "Limited objectives may be particularly appropriate in the case of moderate-income clients." $I d$. He has also suggested adding the following language to the comment: "When providing representation to moderate-income clients, and to other clients, it may be appropriate, after consultation with the client, to limit the representation to providing brief advice such as that which may be available through a bar association, other not-for-profit, or for-profit telephone hotline service." Id.

393. See, e.g., Model Rules of Professional Conduct Rule 1.2 (1998) (duty to accomplish the lawful objectives of a client); $i d$. Rule 1.3 (duty of diligent representation); id. Rule 1.6 (duty of confidentiality); id. Rule 1.7 (duty of loyalty); id. Rule 1.16 (duty not to abandon a client and to protect a client's interests even if the relationship is to be terminated).

394. See id. Rule 1.14. 
contexts do not owe their clients the duty of full representation does not make it so. This is not to criticize the professionalism of the dedicated lawyers who regularly provide limited service to low-income people, who might otherwise receive no legal assistance at all. Rather, it is simply to caution that the ethical questions surrounding limited legal representation are far more complex than may be apparent at first glance.

Presumably, the logical step would be either to amend the Model Rules to clarify the relevant parameters of the attorney-client relationship, or to draft new rules that specifically acknowledge the kind of limited representation contemplated by the Fordham Conference. ${ }^{395}$ But I remain ambivalent about that remedy as well. Even the first step of defining the circumstances in which such limitations would be appropriate may be difficult to accomplish by rule. ${ }^{396}$ But the underlying question goes to the heart of the legal profession's mission of service. As one scholar has put it, the question is whether a boat with one oar is better than no boat at all. ${ }^{397}$ There is a real danger of creating a two-tiered model of legal services, in which the well-to-do get the Mercedes and the less fortunate get the Hyundai. ${ }^{398}$ We cannot ignore the risks to the lay public from establishing a type of professional relationship that may not provide them with the legal protection they need, particularly if the model somehow insulates the lawyer against all malpractice liability. ${ }^{399}$ On the other hand, it is a so-

395. See Green, supra note 364, at 1729 ("The obligations of lawyers giving brief advice to individuals should be addressed by a rule, whether these individuals are characterized as 'clients,' 'prospective clients,' or 'non-clients;' and the obligations identified in the rule should make sense for legal services lawyers no less than corporate lawyers.").

396. See McNeal, supra note 364, at 2622 (noting the difficulty of defining scenarios in which legal professionals could "provide accurate, helpful assistance based only upon minimal facts offered by the client").

397. See generally McNeal, supra note 364 .

398. A skeptic might argue that an unbundled relationship that excludes the duty of diligence is so stripped down that it more resembles "Adobe," a fictional car in a Saturday Night Live commercial parody that was made entirely of clay.

399. The tension that unbundling legal services may create between the "two potentially conflicting values [of] expanded access to the system of justice and protection of the public" is discussed in CANTRIL, supra note 363, at 14; see also Mosten, A Key Component, supra note 376 , at 14 (proposing that "civil immunity be statutorily granted to unbundling lawyers in respect to any lawyering task or issue not specifically undertaken by the lawyer if a legislatively-approved discrete task engagement letter agreement is signed by the client," but noting that in the absence of such statutory authority, lawyers attempting to limit liability by contract will have "shallow safe harbor"); Mosten, Family Lawyer, supra note 376, at 431 ("The public 
bering experience to read posting after posting on the Web by laypeople who obviously need legal help and cannot afford it. My concern is that the bar's historic ambivalence about technology not become the driving force behind efforts to regulate Internet advicegiving. Nevertheless, I believe it is premature to decide whether a new model of attorney-client relationship is needed, at least when there is little research currently available on whether the possible harms to less sophisticated consumers from limited legal assistance would be offset by the benefits from having access to at least some legal advice. ${ }^{400}$

As the new century dawns, we must remember that the technological challenges that confront our profession are not unprecedented. In the same way that our predecessors in the law sought to adapt common law principles to the dramatic social changes wrought by the Industrial Revolution, ${ }^{401}$ so we inevitably shall struggle to determine how twentieth-century legal principles can be harmonized with the vastly expanding technological advances of the next century. As lawyers begin to take their first tentative steps into the brave new world of cyberspace, we too will have to reconcile traditional approaches to the practice of law with the host of new possibilities that world presents. ${ }^{402}$ Indeed, in light of the exponential growth of Inter-

policy of protecting clients and their rights to pursue malpractice claims may conflict with the public policy of providing legal access through limited scope lawyer representation.").

400. One last point that merits further study is the issue of practicing law across state lines as it undoubtedly will arise in cyberspace. The question of loosening traditional restrictions on multijurisdictional practice has come to the fore in recent years, but little formal attention has focused to date on how use of the Internet by lawyers is likely to accelerate this development. See, e.g., Symposium, Ethics and the Multijurisdictional Practice of Law, 36 S. TEX. L. REV. 657 (1995) (discussing ethical rules governing multijurisdictional practice, without raising issues relating to the Internet). At present, however, lawyers who give specific advice to laypeople online ought to ensure that they are providing that service only as to jurisdictions in which they are licensed to practice, in order to avoid becoming test cases for the application to the Internet of statutes governing the unauthorized practice of law.

401. For discussions of past efforts to reconcile such changes, see HURST, supra note 178, at 10-11, who states that "the law has almost always been acted upon by, or has responded to, technological change, rather than controlled it . . . See generally MORTON HOROwITZ, TRANSFORMATION OF AMERICAN LAW (1992) (tracing the progression of legal thought against the background of an evolving political, social, and economic atmosphere).

402. Some have suggested that the legal profession must transform itself in response to the challenges of cyberspace, or risk extinction. The most ambitious analysis of this issue is found in M. ETHAN KATSH, LAW IN A DIGITAL WORLD (1995). Katsh asserts:

The next generation of lawyers cannot rely on the exclusionary powers of state-imposed or print-imposed boundaries to maintain the status, power, and distinction enjoyed by the profession in the past. If lawyers are to survive better than scribes or calligraphers did in the post-Gutenberg world, they need to do more than adapt new technologies to traditional practices and processes. 
net use in the last few years, one might easily argue that lawyers who fail to avail themselves of the new technology will be doing a disservice not only to themselves but also to their clients. ${ }^{403}$ Whatever path we take as a profession, we should ensure that lawyers harness the power of new technology not to protect economic self-interest, but to serve the future hour.

The story of the Good Will Court may yet be told again, but this time we can decide how the story will come out. History need not repeat itself. We as a profession are capable of responding to the challenges posed by the Digital Revolution. If we act with imagination and with boldness, we can harness the transformative power of computers to further our ability to provide legal services to those who need them. Or else, like Clarence Seward in the days of old, we can refuse to take the elevator.

Id. at 94 .

403. Cf. The T.J. Hooper, 60 F.2d 737, 740 (2d Cir. 1932) (imposing negligence liability for failure to utilize new radio technology that might have prevented the accident). 